

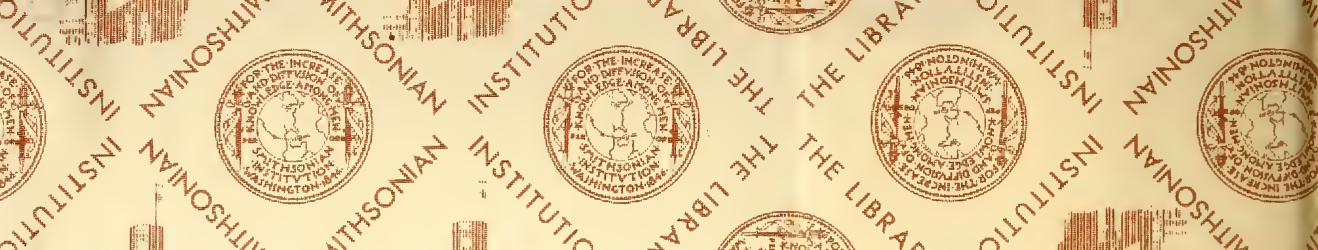

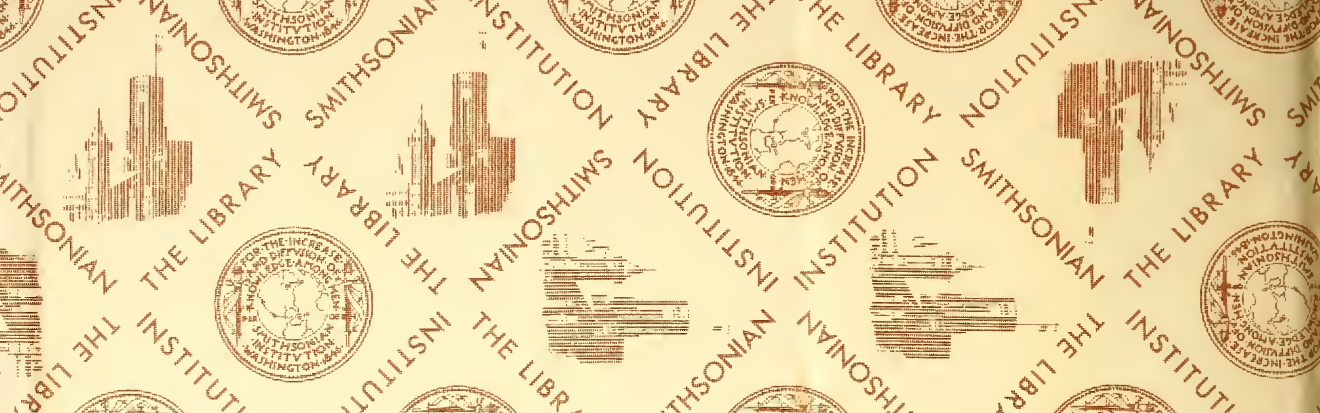

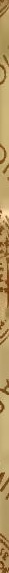
.

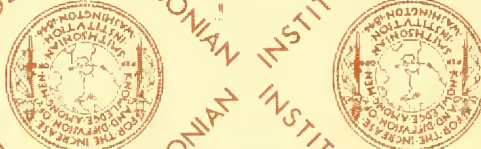

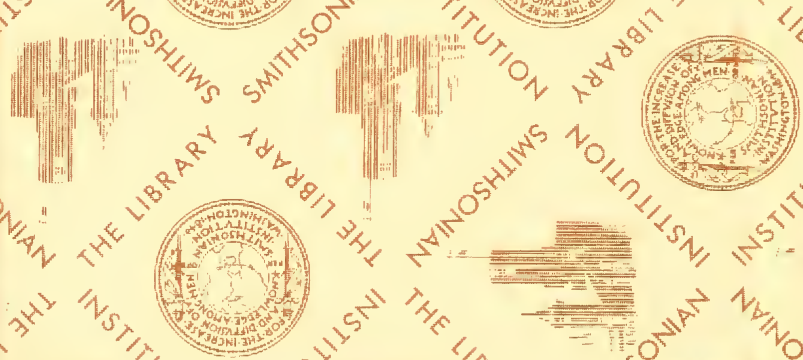<smiles>c1ccccc1</smiles>
(

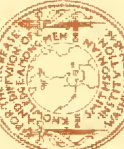
$0 / 3 /, t^{5}$<smiles>c1ccc2ccccc2c1</smiles>

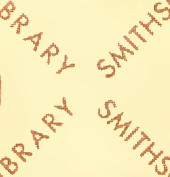

(1),

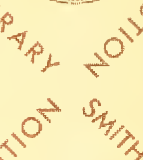

"रs, t5 \%

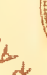
and
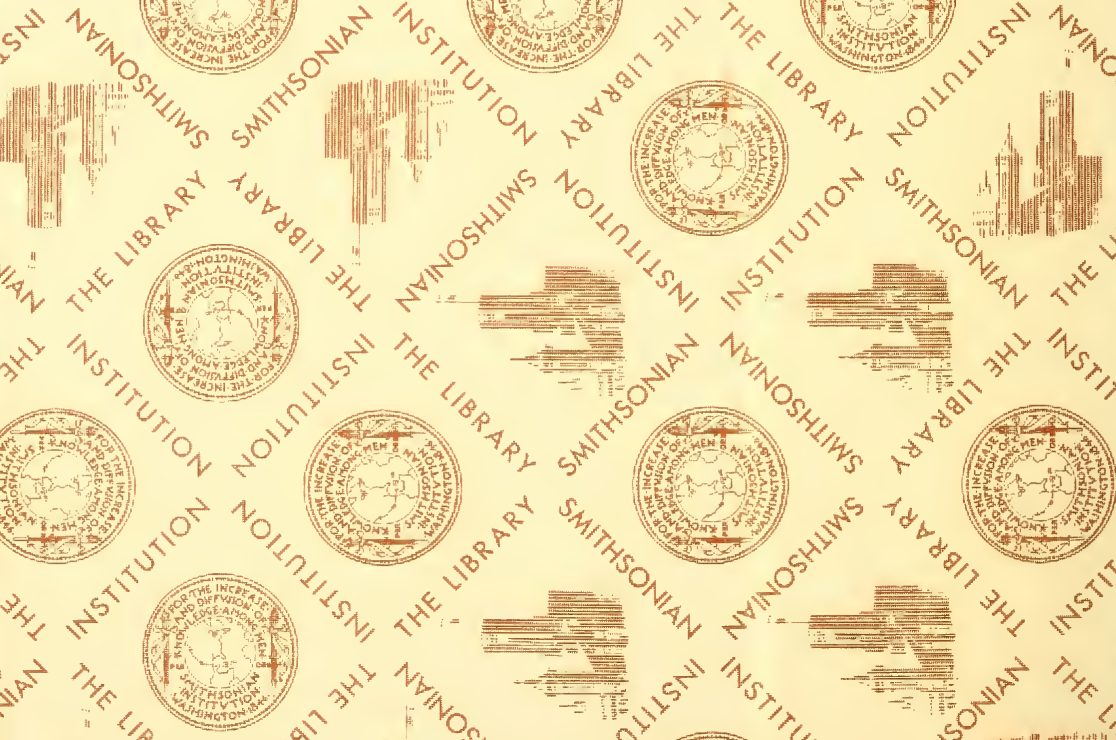

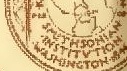

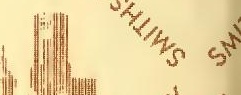

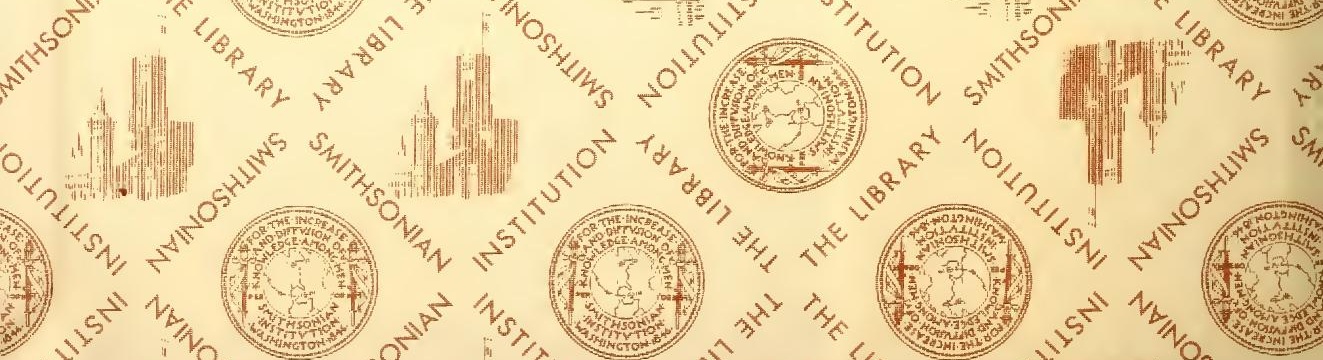

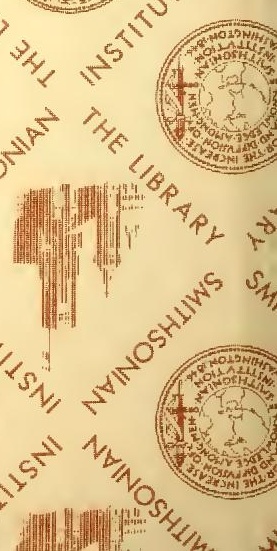




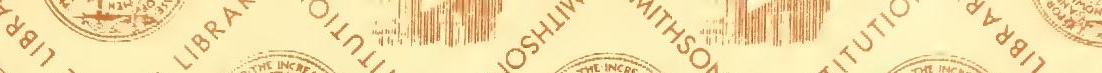

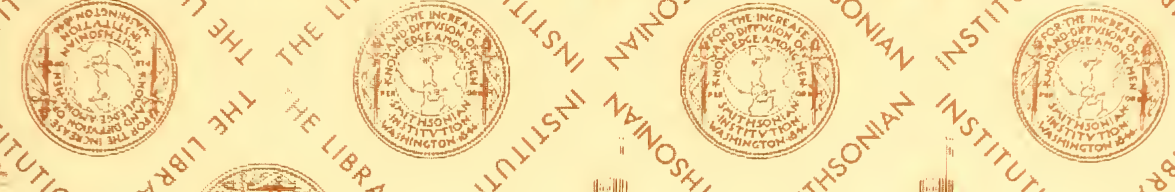

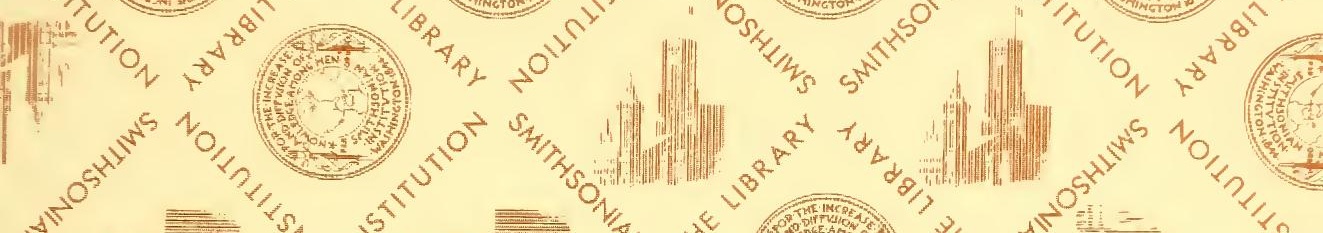

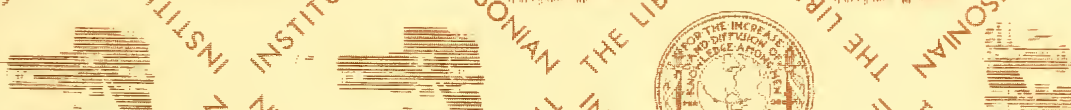

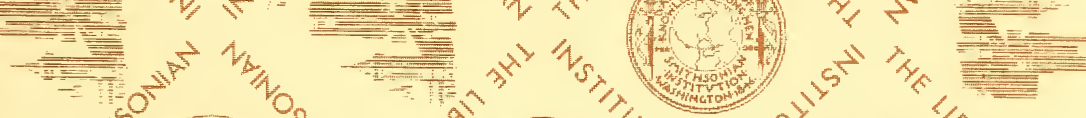

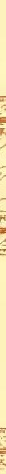

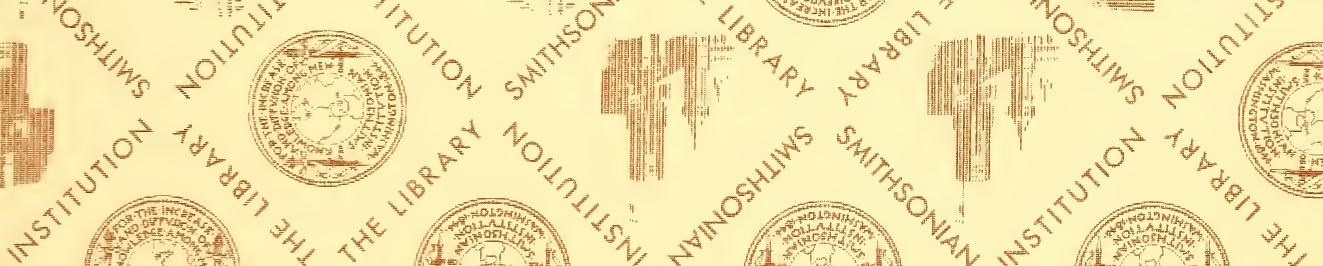
1
3
3

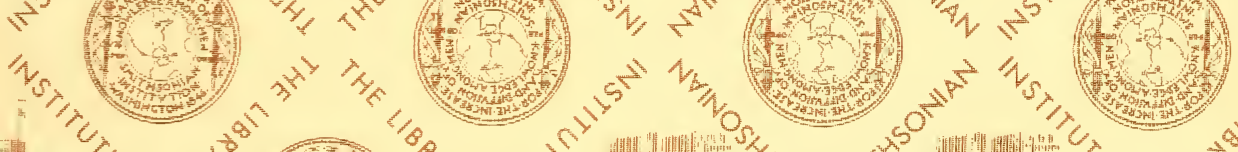

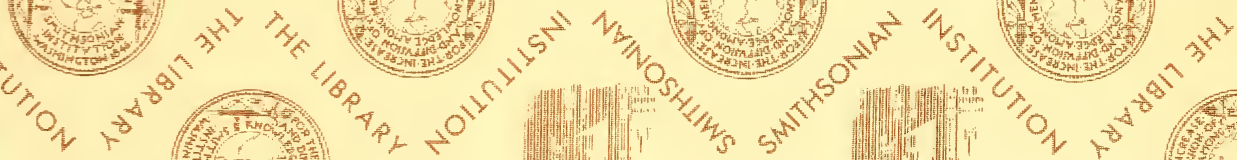

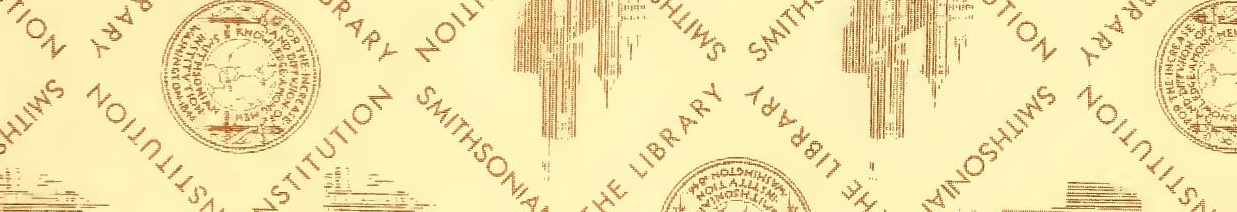

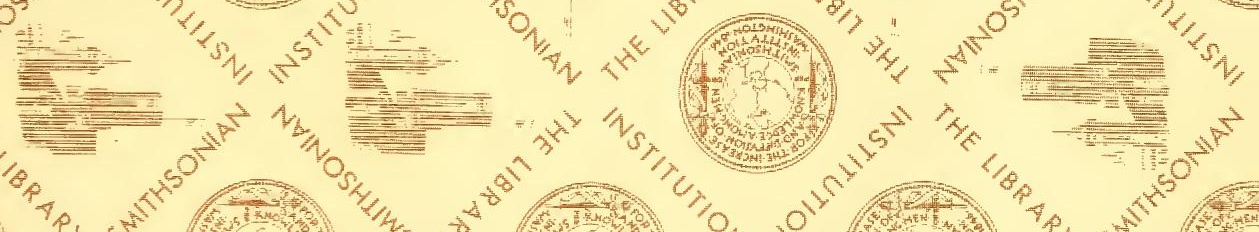

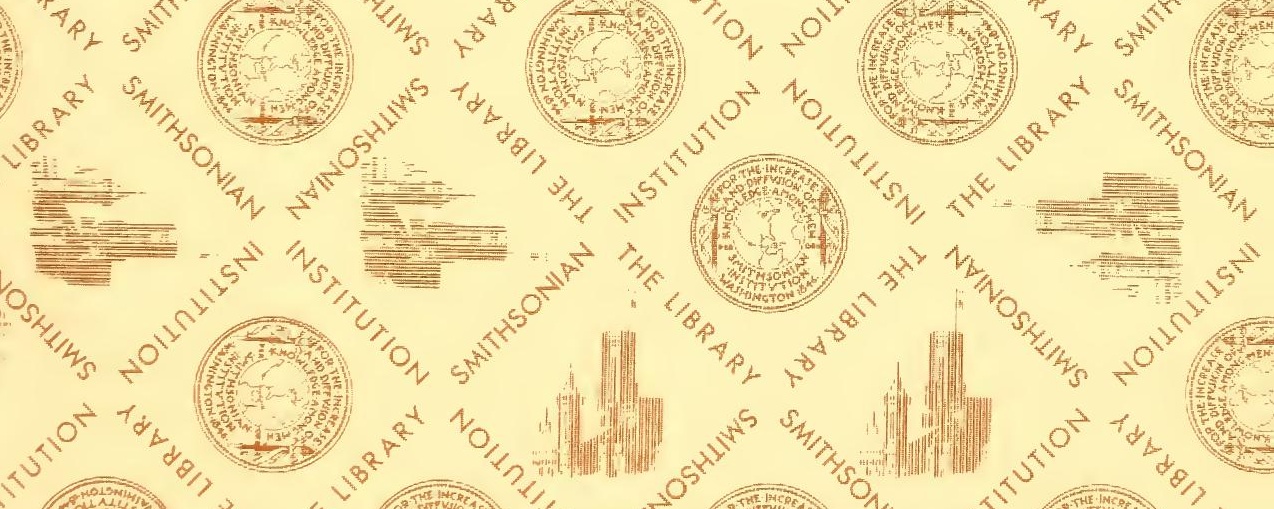

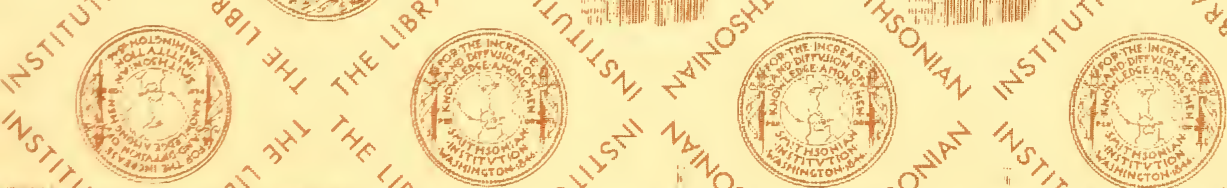







\title{
Philippine Bamboos
}

\author{
By William H. Brown, Ph. D.,
}

Chief, Division of Investigation, Bureau of Forestry; Plant Physiologist, Bureau of Science; and Associate Professor of Botany, College of Liberal Arts,

University of the Philippines

and

Arthur F. Fischer, C. E., M. F.

Director of Forestry; and Dean and Professor of Forestry, School of Forestry, University of the Philippines

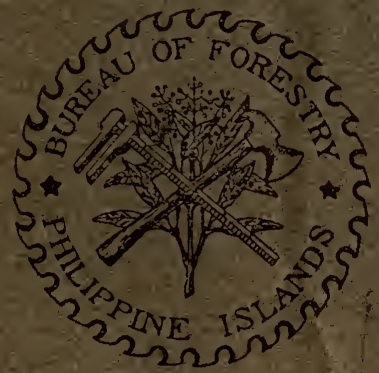

Department of Agriculture and Natural Resources Bureau of Forestry

Bulletin No. 15

Arthur F. Fischer, Director of Forestry

MANILA

BUREAU OF PRINTING

160091

1918 

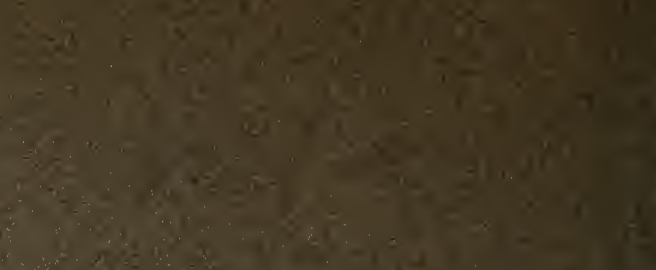



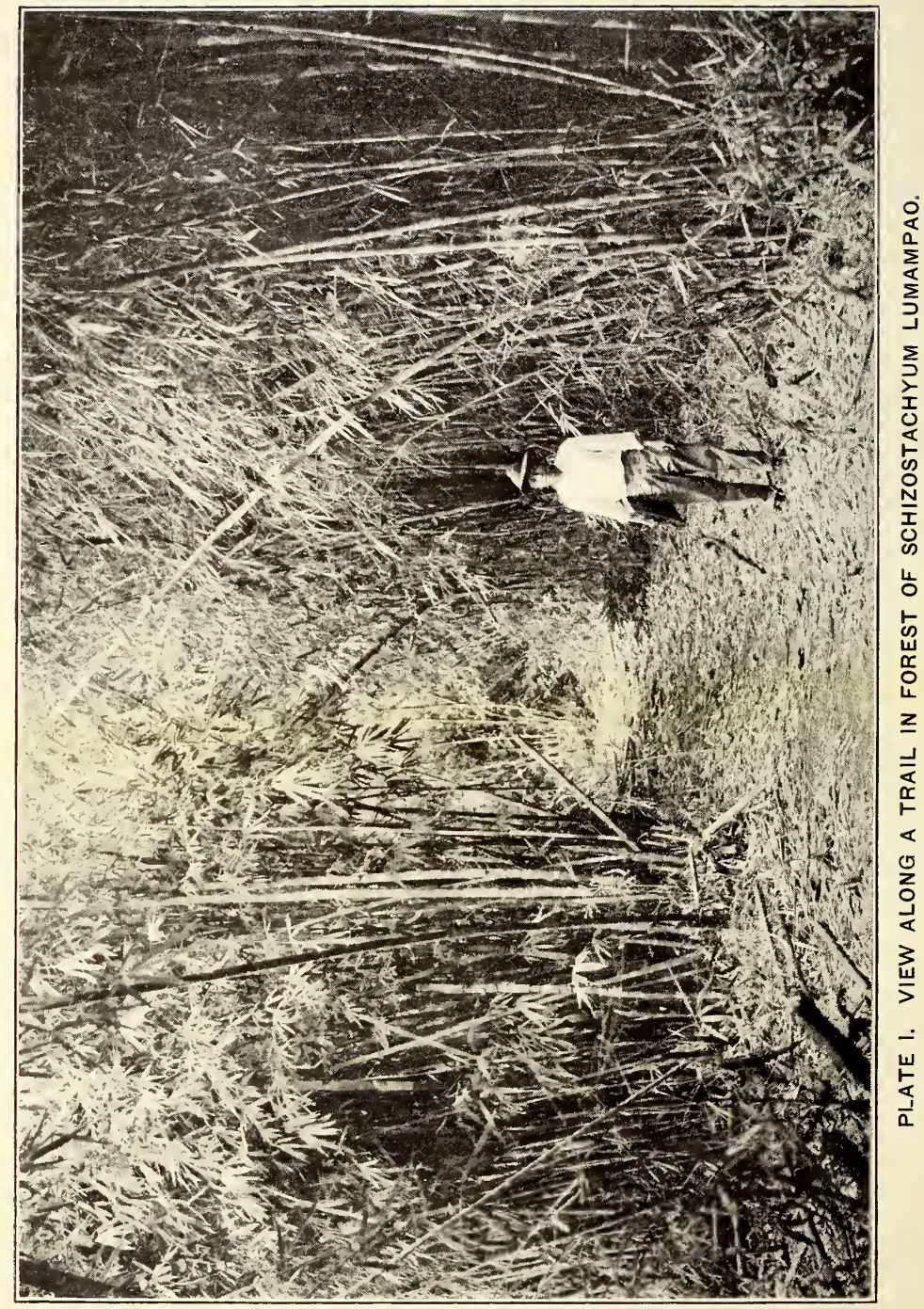




\title{
Philippine Bamboos
}

\author{
By William H. Brown, Ph. D.,
}

Chief, Division of Investigation, Bureau of Forestry; Plant Physiologist, Bureau of Science; and Associate Professor of Botany, College of Liberal Arts,

University of the Philippines

and

Arthur F. Fischer, C. E., M. F.,

Director of Forestry; and Dean and Professor of Forestry, School of Forestry, University of the Philippines

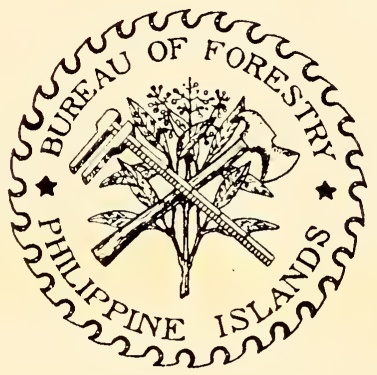

Department of Agriculture and Natural Resources Bureau of Forestry

\section{Bulletin No. 15}

Arthur F. Fischer, Director of Forestry

MANILA

BUREAU OF PRINTING

1918 



\section{CONTENTS}

ILLUSTRATIONS

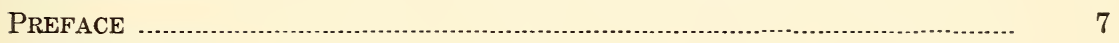

INTRODUCTION _.............................................................................. 9

KEY TO GENERA

DESCRIPTION OF SPECIES.................................................................... 12

Arundinaria .............................................................................. 12

Bambusa ................................................................................... 12

Cephalostachyum ................................................................. 14

Dendrocalamus .............................................................................. 15

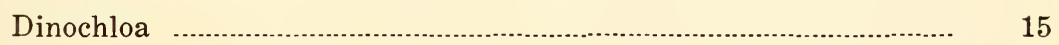

Gigantochloa ….......................................................................... 16

Guadua ......................................................................... 16

Schizostachyum ........................................................................ 17

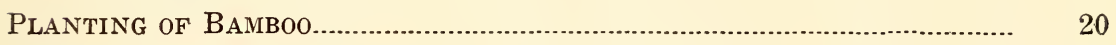

Growth of Mature ClumpS..................................................................... 24

Cost of Harvesting and Prices......................................................... 32 



\section{ILLUSTRATIONS}

Plate I. View along a trail in forest of Schizostachyum lumampco. (Frontispiece.)

II. Arundinaria niitakayamensis Hayata.

III. Bambusa cornuta Munro.

IV. Bambusa merrillii Gamble.

V. Bambusa spinosa Roxb. Clump.

VI. Bambusa spinosa Roxb. Base of clump.

VII. Bambusa spinosa Roxb.

VIII. Bambusa vulgaris Schrad. Clump.

IX. Bambusa vulgaris Schrad. Base of clump.

X. Bambusa vulgaris Schrad.

XI. Cephalostachyum mindorense Gamble. Cotype specimen.

XII. Dendrocalamus merrillianus Elm. Clump.

XIII. Dendrocalamus merrillianus Elm. Cotype specimen.

XIV. Dinochloa ciliata Kurz.

XV. Dinochloa elmeri Gamble.

XVI. Dinochloa luconiae (Munro) Merr. Type specimen.

XVII. Dinochloa pubiramea Gamble. Type specimen.

XVIII. Dinochloa scandens O. Kuntze.

XIX. Gigantochloa levis (Blanco) Merr.

XX. Guadua philippinensis Gamble. Cotype specimen.

XXI. Schizostachyum brachycladum Kurz.

XXII. Schizostachyum dielsianum (Pilger) Merr.

XXIII. Schizostachyum curranii Gamble.

XXIV. Schizostachyum diffusum (Blanco) Merr.

XXV. Schizostachyum fenixii Gamble. Cotype specimen.

XXVI. Schizostachyum hirtiflorum Hack. Cotype specimen.

XXVII. Schizostachyum lima (Blanco) Merr.

XXVIII. Schizostachyum lumampao (Blanco) Merr.

XXIX. Interior of mature forest of Schizostachyum lumampao.

XXX. Schizostachyum luzonicum Gamble. Cotype specimen.

XXXI. Schizostachyum palawanense Gamble. Type specimen.

XXXII. Schizostachyum textorium (Blanco) Merr.

XXXIII. Schizostachyum toppingii Gamble. Cotype specimen. 



\section{PREFACE}

This bulletin is the first of a series to deal with minor forest products. By minor forest products are meant all the products of the forest other than timber, the latter being regarded as the principal product. In the Philippines, as in other tropical forests, the minor products, while of less importance than the timber, are very varied and of great economic value. For this reason, it has been deemed advisable to prepare a series of bulletins dealing with them; particularly as at the present time it is especially desirable to have, in an available form, information concerning our resources. In preparing a work of this kind there are always points concerning which further information would be desirable and in the Philippines there is a great lack of data which would be necessary to make the treatment of the minor forest products reasonably thorough. It is believed, however, that the presentation of such data as we have is advisable particularly as it can then serve as a better starting point for obtaining further information.

The writers are greatly indebted to Mr. E. D. Merrill, of the Bureau of Science, for valuable assistance and suggestions and to Dr. F. W. Foxworthy, formerly chief of the Division of Investigation, Bureau of Forestry, for extensive records left with the Bureau and for helpful criticisms of the present paper. Without the information obtained from Mr. Merrill and from the records left by Dr. Foxworthy, the preparation of the present bulletin would have been impracticable. The authors are indebted to Mr. R. C. McGregor for assistance in preparing this manuscript for the printer.

All plates except VI, VIII, IX, and XXIX are from photographs taken for the writers through the courtesy of the Bureau of Science, Manila, by their official photographer, Mr. E. Cortes. 



\section{PHILIPPINE BAMBOOS}

\section{By William H. Brown and Arthur F. Fischer}

\section{INTRODUCTION}

The bamboos form a section of the grass family and contain the largest known grasses, many of which are of tree size. Bamboos, according to form, can be divided into three classes: clump-forming erect species; erect ones which send up shoots singly from an underground stem; and climbing bamboos. Erect clump-forming species are characteristic of tropical countries, while those which send up shoots singly are more characteristic of subtropical or temperate regions. Bamboos are the most useful plants for domestic purposes in the Philippine Islands. Their most promising possibilities for export are as paper pulp, hats, baskets, mats, and matting. These products will be discussed in later bulletins.

In the Philippine Islands are found about 30 species of bamboo, 17 erect and 13 climbing, as follows :

\section{ERECT}

Arundinaria niitakayamensis Hayata. Bambusa cornuta Munro.

Bambusa glaucescens (Willd.) Sieb. Bambusa merrillii Gamble.

Bambusa spinosa Roxb.

Bambusa vulgaris Schrad.

Bambusa vulgaris striata Gamble.

Dendrocalamus latiflorus Munro.

Dendrocalamus merrillianus Elm.

Gigantochloa levis (Blanco) Merr.

Guadua philippinensis Gamble.

Schizostachyum brachycladum Kurz.

Schizostachyum hirtiflorum Hack.

Schizostachyum lima (Blanco) Merr.

Schizostachyum lumampao (Blanco)

Merr.

Dendrocalamus curranii Gamble.

\section{CLIMBING}

Cephalostachyum mindorense Gamble.

Dinochloa ciliata Kurz.

Dinochloa elmeri Gamble.

Dinochloa luconiae (Munro) Merr.

Dinochloa pubiramea (Merr.) Gamble.

Dinochloa scaridens O. Kuntze.

Schizostachyum luzonicum Gamble.

Schizostachyum curranii Gamble.

Schizostachyum dielsianum (Pilger) Merr.

Schizostachyum diffusum (Blanco) Merr.

Schizostachyum fenixii Gamble.

Schizostachyum palawanense Gamble.

Schizostachyum textorium (Blanco) Merr.

Schizostachyum toppingii Gamble.

At present the climbing bamboos are of slight commercial importance, and are rather a disadvantage than an advantage, as they occupy space which might be utilized by more valuable plants. They grow at the edge of the forest or in deserted caingins, ${ }^{1}$ or in the forest whenever space has been opened up

${ }^{1}$ A word used in the Philippines for a clearing made for temporary cultivation. 
by the falling of large trees. They require considerable insolation for their best development and then grow very densely-so densely that it is very difficult to penetrate the thickets formed. In fact climbing bamboo forms the most impenetrable thickets that are to be found in our forests. They seem to be decidedly inimical to tree growth, and are hard to eradicate when once they have fully occupied an area.

The erect species may, for convenience, be divided into thickand thin-walled bamboos. The frame work of a great majority of the houses in the Philippine Islands is constructed from the thick-walled species. Unsplit culms are used for posts, beams, and rafters. The same species, when split and flattened, are used for the sides of houses; or when split in two employed like tiles for roofing. Most frequently the sides and partitions, and occasionally the floors, are formed from thin-walled species split and woven into a coarse matting (sawale).

Sawale is a promising material for the construction of lightmaterial bungalows even in temperate countries. It is also very attractive as an interior finish in strong-material houses. Sawale is of particular advantage in the construction of large temporary buildings. In Manila there is held an annual Carnival, in which very imposing structures are constructed rapidly and cheaply with the aid of this material. When the Philippine National Guard was organized, all the barracks were constructed very quickly on account of the use of sawale. In the entire Philippine exhibits at the Panama-Pacific International Exposition at San Francisco, California, various weaves and classes of sawale were used extensively in the installation of the different booths. This proved so attractive and demonstrated so clearly its use, that people visiting the Exposition ordered material of the heavier weave for summer cottages in California. These orders, aggregating 3,000 linear yards, were for the kind of material used in the exhibits. It was only due to a lack of an organized industry and the subsequent rise in freight rates that a considerable export trade did not result from this beginning.

The domestic uses of bamboo are innumerable and include bridges, fences, rafts, fish-traps, vessels for carrying and storing water, cooking, splints for baskets, hats and mats, vehicle shafts, chairs, cupboards, tables, beds, benches, flower pots, etc. In fact, on account of the ease with which it is worked, bamboo is used for almost every purpose for which wood is employed in temperate countries. The young shoots of many species are also used for food. As an interesting use of bamboo we may mention that complete bands, in some cases having 32 or more pieces, 
are equipped with musical instruments constructed of bamboo. These pieces are of the same general character as brass instruments and include horns, clarinets, flageolets, saxophones, flutes, piccolos, and drums. A church in Las Piñas, a few kilometers from Manila, has a famous organ with bamboo pipes.

For construction purposes bamboo should be cut a year after it has reached mature size and after the rainy season; that is, in most part of the Philippines, after November. If cut during the rainy season the culms are full of sap, which soon attracts small beetles in great numbers and these rapidly destroy the bamboo. In practice, newly cut bamboo is often kept in water for several weeks in order that the sap, or at least the sugar and starch contents of the sap, may be eliminated. Filipino bamboo carpenters say that when flies gather around the newly worked bamboo, it is a sign that this bamboo is not durable. The flies, of course, are attracted by the sugar in the bamboo.

Owing to the wide distribution of bamboo and the ease with which it is worked without any special implements, it offers a promising field for the development of local household industries for the manufacture of various useful and ornamental articles. If this industry were developed, no doubt considerable export trade could be secured.

1. Climbing.

Key to the genera of Philippine bamboos.

2. Flowers in widely scattered, dense, globose heads; rare, known only from Mindoro Cephalostachyum.

2. Flowers not in widely scattered, dense, globose heads.

3. Spikelets very small, ovate..

Dinochloa.

3. Spikelets elongated, linear or linear-lanceolate.

Schizostachyum.

1. Erect.

2. Two and a half meters in height or less, only on high mountains, wild Arundinaria.

2. Clumps one to three meters in height, leaves small and whitish, cultivated only. Bambusa glaucescens.

2. More than 3 meters in height.

3. Base of clump protected with long interlaced spiny branches.

Bambusa spinosa.

3. Base of clump not protected with long spiny branches.

4. Culms thin walled; mostly small or medium sized bamboos.

5. Keels of palea broadly winged; rare, known only from Mindanao. Guadua.

5. Palea not winged Schizostachyum.

4. Culms thick walled; mostly large bamboos.

5. Pericarp thin, adnate to the seed.

6. Filaments free. Bambusa.

6. Filaments connate in a thin tube.... Gigantochloa.

5. Pericarp fleshy or crustaceous, separable from the seed Dendrocalamus. 


\section{DESCRIPTION OF SPECIES}

Genus ARUNDINARIA Michaux

ARUNDINARIA NIITAKAYAMENSIS Hayata.

UTOD.

Among the Igorots, this bamboo is known as utod. It is the only representative of the genus found in the Philippines. This species was originally described from the mountains of Formosa, and is known only from Formosa and the mountains of Luzon. It is locally very abundant, forming dense thickets, at altitudes from 2,100 to 2,600 meters in the Mountain Province, Luzon. This bamboo reaches a height of 2.5 meters, but in unfavorable habitats is frequently only a few centimeters in height. Its maximum diameter is about 1 centimeter. Its only recorded use in the Philippines is for pipestems. A flowering specimen is shown in Plate II.

\section{Genus BAMBUSA Schreber}

1. Culms unarmed.

2. Small shrubby species 2 to 3 meters high with glaucous leaves.

B. glaucescens.

2. Coarse species of tree size.

3. Leaf-sheaths with rounded auricles B. vulgaris.

3. Leaf-sheaths with hornlike, erect processes.

4. Leaves large; spikelets glabrous; keels of the palea not prominently ciliate.

B. cornuta.

4. Leaves small; spikelets densely hirsute; keels of the palea prominently ciliate B. merrillii.

1. Culms spiny

B. spinosa.

The genus Bambusa is represented by five species, of which at least three appear to have been purposely introduced. It includes the most valuable single species of the entire group in the Philippines. With one exception, all of the species have large, tall culms.

BAMBUSA CORNUTA Munro.

LOPA.

Common name: lopa (Isinai).

Rare in the forests of Nueva Vizcaya and Benguet, known also from Java. An erect bamboo reaching a height of 7 to 8 meters, and a culm diameter of 3 to 3.5 centimeters, with internodes 40 to 45 centimeters long. It is characterized by prominent horns at the tip of the leaf sheath. A flowering specimen is shown in Plate III.

BAMBUSA GLAUCESCENS Sieb.

KAWAYAN-CHINA.

Common names: kawayan-china, kawayan-sina (Tagalog).

Kawayan-china is a native of China or Japan and occurs in the Philippines only as an introduced and cultivated plant. 
The clumps are usually from 1 to 3 meters in height, the culms up to 2 centimeters in diameter. The culms may be 5 meters in length but when long are usually much bent. The leaves are from 3 to 10 centimeters long and whitish in appearance. This species is planted for ornamental purposes and in some parts of Manila is used as a hedge plant. The stems are used for lishing rods.

\section{BAMBUSA MERRILLII Gamble.}

This species is known only from collections from the Caraballo Sur mountain ranges in Nueva Vizcaya, where it grows in forests at an altitude of about 600 meters.

It is an erect straggling species about 18 meters in height. See Plate IV.

BAMBUSA SPINOSA Roxb. (B. blumeana Schultes f.). SPINY BAmboo.

Common names: dugían, kabugáwan, marurúgi, rugían (Bikol) ; kawáyan, kawáyan totóo (i. e. true bamboo), kawáyan tiník (Tagalog); aon-o, batákan, paua, kawáyan-gid (Bisaya); kawáyan si-ítan (Iloko); bayog (Zambales); lam-nuan (Isinai); baugin (Pampanga); pasingan (Cagayan) ; caña espina (Spanish).

This bamboo is the one to which the name kawayan is most frequently applied. It is found throughout the settled areas of the Philippines at low and medium altitudes, and is apparently always planted, there being no valid reason for considering it a native of the Archipelago. This bamboo was apparently purposely introduced at an early date. Spiny bamboo, as well as the other large, probably introduced species, has been cultivated quite extensively in clearings which have since been abandoned, so that considerable areas are now covered by virtual forests of this species. Spiny bamboo offers considerable possibilities as a valuable reforestation crop.

Spiny bamboo reaches a height of about 25 meters and a culm diameter of 20 centimeters. The internodes are usually hollow, and from 40 to 60 centimeters in length. The culms have thick walls, becoming progressively thicker toward the lower part of the culm. It occasionally happens that the lower internodes are so thick walled that they become almost or quite solid. The stem contains a large amount of silica and sometimes an internode is completely filled with a hard white siliceous mass, which damages any instrument use in cutting it. This bamboo is rarely found in flower and the interval between flowering periods is not known. It is by far the most commonly used bamboo in the Philippines, being prized above all others by the Filipinos for building purposes on account of its great strength and durability. It is distinguished from all other spe- 
cies of Philippine bamboos by the fact that it grows in large clumps, the basal portions of which are surrounded to a height of from 2 to 3 meters by a densely interlaced thicket of very spiny branches, which make access to the culms exceedingly difficult. The function of these spiny branches, apparently, is to protect the delicate young shoots from herbivorous animals. This species is illustrated in Plates V to VII.

The splints from green stems of this species are used extensively in the manufacture of baskets and hats, it being the most valuable species for hatmaking. It also has some commercial possibilities for paper pulp. The basal portions of the culms have been used as heads for polo mallets and for shuttles on hand looms.

Distributed in southern China, Indo-China, Malay Peninsula, and Malay Archipelago.

BAMBUSA VULGARIS Schrad.

KAWÁYAN-KILÍNG.

Common names: kawayan-kiling, kawayan bayúgin, kawayan hobéro, taiwanák, tewanák (Tagalog); bulínau, burírau, lúnas, sinambáng (Bisaya); kabolóan (Bikol).

This is a clump-forming spineless bamboo, which reaches a height of about 17 meters or more and a diameter of about 12 centimeters. The stems are smooth, usually yellowish or yellowish-green. It is usually smaller than Bambusa spinosa and has thinner walls. This species is illustrated in Plates VIII to $\mathrm{X}$.

Kawayan-kiling is one of the building bamboos and is generally utilized in the regions where it grows for the various purposes, such as house construction, bridges, furniture, for which the coarse erect bamboos are adapted. It is much inferior to Bambusa spinosa. Like the spiny bamboo, it is probably not a native of the Philippines, but was purposely introduced in prehistoric times on account of its general utility. The variety striata Gamble is occasionally cultivated in Manila and in other large towns for ornamental purposes; it is readily distinguished by its culms being bright yellow with a few green stripes. This form is a native of China or Japan, but is now widely distributed in cultivation.

The native country of Bambusa vulgaris is so far unknown; it is cultivated and half wild in Asia, Africa, and America.

\section{Genus CEPHALOSTACHYUM Munro}

CEPHALOSTACHYUM MINDORENSE Gamble.

BAKTO.

This species is rare and known only from Mindoro. It is a climbing species well characterized by having its flowers in 
dense globose, widely scattered heads the larger of which are about 2 centimeters in diameter. See Plate XI.

\section{Genus DENDROCALAMUS Nees}

Spikelets large; leaves large

D. latiflorus.

Spikelets medium-sized; leaves long

D. curranii.

Spikelets very small

D. merrillianus.

This genus of large erect bamboos is represented by three species. It is economically unimportant and none of the species are especially abundant.

DENDROCALAMUS CURRANII Gamble.

A rare species known only from Sampaloc, Tayabas, and the Island of Polillo off the coast of Luzon, and possibly not distinct from Gigantochloa levis.

DENDROCALAMUS LATIFLORUS Munro.

Botóng.

Common names: botóng, bolong-sína (Bikol, Bisaya); butún (Bisaya); kabolóan, patóng (Bikol); kawáyan-sína (Tagalog).

This is a tall, tufted, spineless bamboo apparently of general distribution in the central Philippines. It is frequently utilized for building purposes, but is not considered to be good material for basketry.

DENDROCALAMUS MERRILLIANUS Elm.

BAYOG.

Common names: bayóg (Ilocos); kawáyan-bayóg' (Pangasinan).

This bamboo is apparently widely distributed in the Philippines. It is a tall graceful bamboo with slender stalks forming large clumps. The culms have very thick walls and prominent nodes. They are used for vehicle shafts and for other purposes where great strength is desired. The green culms of this bamboo are split and made into ropes, used particularly for hauling logs. A flowering specimen is shown in Plate XII.

1. Woody.

Genus DINOCHLOA Büse

2. Leaves broad.

3. Lodicules absent; caryopsis globose; floral rachis glabrous.

D. scandens.

3. Lodicules present; caryopsis oblong; floral rachis pubescent.

2. Leaves narrow; no lodicules.

D. pubiramea.

3. Culms smooth; caryopsis globose

D. ciliata.

3. Culms rough; caryopsis oblong. D. luçoniae.

1. Herbaceous, or woody only at the base; lodicules present. D. elmeri.

The genus Dinochloa is represented in the Philippines by five species. With one exception our representatives are all scandent, thick-walled, sylvan forms and are locally very abundant, forming almost impenetrable thickets under favorable conditions. 
No special economic uses are indicated for any of the forms, yet like all bamboos they are more or less utilized by the Filipinos for general purposes. They should be adapted to the same special uses as the thick-walled scandent species of Schizostachyum. The most common species is Dinochloa scandens, zigzag bamboo, (Plate XVIII) which is abundant and widely distributed in the central and southern Philippines; it is characterized by its very broad leaves and is variously known as baía in Palawan, bokáue in Balabac, bukáu in Basilan, usíu, timák, and bolokáui in Mindoro. Most of these names are also used for the scandent species of Schizostachyum. Dinochloa luçoniae (Plate XVI) is very similar in general character to Dinochloa scandens, but has much narrower leaves, which is also true of Dinochloa ciliata (Plate XIV). Dinochloa luçoniae is known as baíto (Tagalog) and esu (Iloko). D. pubiramea (Plate XVII) is a broad leaved species similar to $D$. scandens and distinguished chiefly by having the branches of the inflorescence pubescent. Its local names are kandy (Bis.) and bukáo (Moro). Dinochloa elmeri (Plate XV) is a dwarfed, half woody form growing in the mossy forest at the summits of high mountains.

\section{Genus GIGANTOCHLOA Kurz}

GigANTOCHLOA LEVIS (Blanco) Merr.

Bolo.

Common names: kawáyan-bóo, kawayan-sina, kawáyan-putí, bohó (Tagalog) ; bokó, boló, botóng (Bisaya).

Gigantochloa levis is a stout bamboo reaching a height of 20 meters or more and a culm diameter of 20 centimeters. Its culms are very straight and smooth, dull green, covered with siliceous pubescence, and entirely unarmed. It is found in and about towns in the settled areas of the Philippines, and also in the forests. The stems are used as pipes for temporary water supplies, as they are usually long and straight, and for building fish traps. They are, apparently, rarely employed in building operations, except for walls of houses, perhaps because they are not especially durable. A flowering specimen is shown in Plate XIX.

The Philippine specimens referred to Gigantochloa robusta Kurz and Gigantochloa atter Kurz are not considered by Mr. E. D. Merrill to be specifically distinct from G. levis.

\section{Genus GUADUA Kunth}

GUADUA PHILIPPINENSIS Gamble.

This is a rare species known only from a single collection from Mindoro. The nodes are reported to be about 75 centimeters 
long and 2.5 to 5 centimeters in diameter. The culms are thinwalled and 4 to 6 meters in height. A cotype specimen is shown in Plate XX.

\section{Genus SchizostachyUm Nees}

1. Climbing.

2. Flowers in long panicles, usually from flower-bearing culms or auxillary on leafy ones.

3. Leaves usually broad, rounded at the base, mouth of leaf sheaths and ligules long-bristly-ciliate.

4. Spikelets glabrous.

S. diffusum.

4. Spikelets densely pubescent. S. fenixii.

3. Leaves usually narrow attenuate at the base, mouth of leaf sheaths and ligules not or only slightly bristly.

4. Spikelets very sharply pointed; apicules of anthers shortly hirsute. S. dielsianum.

4. Spikelets acute only; apicules of anthers very long bristly.

S. palawanense.

2. Flowers in short, terminal spikes up to 10 centimeters long; leaves very narrow.

S. textorium.

1. Erect.

2. Spikelets sharply pointed, not in rounded capitula.

S. longispiculatum.

2. Spikelets sharply pointed, usually in rounded capitula; no lodicules.

3. Spikelets glabrous outside.

4. Internodes about a meter or more in length or longer.

S. lima.

4. Internodes shorter.

S. brachycladum.

3. Spikelets more or less pubescent outside; anthers obtuse.

4. Spikelets densely white-hairy, both on the empty and on the flowering glumes; leaves 1 centimeter broad.

S. hirtiflorum.

4. Spikelets shortly white-hairy only on the flowering glume; leaves over 1.5 centimeters broad............... S. lumampao.

2. Spikelets hardly sharp-pointed, obtuse or acute, usually in long panicles; lodicules usually present.

S. luzonicum.

The genus Schizostachyum is extensively developed in the Philippines. Among the bamboos it has by far the largest number of species, and presents several of the most common and widely distributed bamboos in the Archipelago. All of the species are indigenous, and none of them are cultivated. The genus contains both erect, thin-walled species, and scandent thick-walled ones, several of which are used for special purposes. None of the species are of large size. Most of them are sylvan or subsylvan and usually do not occur in the open settled areas. Several of them are gregarious and in some provinces occupy rather large areas of land to the practical exclusion of other vegetation.

SCHIZOSTACHYUM BRACHYCLADUM Kurz.

Common names: bohó (Isinai and Mindanao) ; bagákai (Leyte); bagákan (Palawan). 
This is an erect bamboo about 10 meters in height and up to 5 centimeters in diameter. A gregarious species abundant in Palawan and Culion on dry open slopes. Reported from Nueva Vizcaya, Leyte, Butuan, and Palawan. A flowering specimen is shown in Plate XXI.

SCHIZOSTACHYUM DIFFUSUM (Blanco) Merr.

BÍKAL.

Common names: bikal (Tagalog, Iloko, Pampanga, Pangasinan, Cagayan) ; usíu (Tagalog); baliáro, balikáu, bongbong, lo-ob (Bisaya); hindi, indi, inri (Bikol); butor (Isinai) ; bábui (Bikol).

Bikal is widely distributed in the forests of the Philippines and is endemic. It is characterized not only by its habit, but also by its very thick walls. Sometimes the lumen is almost entirely wanting, especially in the lower parts of the stem. The plant is well known to all Filipino woodsmen as a source of drinking water, as water of good quality can be secured from the internodes. In some parts of the Philippines this bamboo is extensively used in making baskets, while it is now beginning to attract attention for the purpose of making chairs, for which it is adapted on account of its thick stout walls. A flowering specimen is shown in Plate XXIV. The very closely allied Schizostachyum dielsianum, bikal-bábui, (Plate XXII) has the same names, distribution, and uses as $S$. diffusum, and is distinguished only by minor characters.

SCHIZOSTACHYUM LIMA (Blanco) Merr.

Anos.

Common name: anos (Tagalog).

This endemic, erect, thin-walled bamboo is distinguished among all the Philippine forms by its long internodes, which are usually about one meter in length. It is sometimes called boló and bagákai by confusion with Schizostachyum lumampao. It is used by the Filipinos for making blow guns, while the cortex is hard and rough and can be used for polishing brass. It is also used for the various purposes for which all thin-walled bamboos are utilized, and after boiling, even for weaving fans, cushions, and hats; broad splints prepared from it are used in making the broad shallow baskets used for winnowing rice. Widely distributed in the Philippines. A flowering specimen is shown in Plate XXVII.

SCHIzOSTACHYUM LUMAMPAO (Blanco) Merr. BÚHo or CAÑA-Bojo.

Common names: caña-bojo (Spanish-Filipino); bólo, boho, lumampáu, bokáui, kauáyan-songsóng (Tagalog); bagákan, bagákai (Bisaya); búlu, bolo (Bisaya, Iloko); orás (Bikol).

This species is endemic and widely scattered in the Philippines. It is a thin-walled, erect, gregarious bamboo usually reaching 
a height of about 10 meters, and often nearly exclusively occupying considerable areas. Forester Medina has surveyed two tracts of this bamboo in Bataan Province, one containing 1,200 hectares, of which 800 hectares have a dense stand; the second containing 650 hectares, of which more than 40 per cent is covered with Schizostachyum lumampao. There are also very extensive areas in other parts of Bataan, in Zambales, and in the Cagayan Valley. Fifteen small plots of Schizostachyum lumampao have been measured in Bataan Province back of the town of Limay. These plots aggregated 3.5 hectares and covered stands at widely separated intervals. The surveys showed an average of 8,983 canes per hectare. One of the surveys of one quarter of a hectare indicated a stand of 19,162 canes per hectare.

This thin-walled bamboo is the species chiefly utilized in making the building matting known as sawale. It is also used for making baskets, fences, fish corrals, fish poles, flutes, and for many other purposes.

Buho has been thoroughly investigated by Richmond as a paper-making material, and it is probably the one species of Philippine bamboo that, without extensive cultivation, promises commercial possibilities for this purpose. This point will be discussed in a bulletin on paper. Observations on its rate of growth are given later. This species is illustrated in Plate I (frontispiece) and Plates XXVIII and XXIX.

SCHIZOSTACHYUM TEXTORIUM (Blanco) Merr.

KALBÁNG.

Common name: kalbáng (Tagalog).

This is an erect bamboo with small leaves, which is locally abundant in the Provinces of Batangas and Rizal, Luzon. The stems are used in the manufacture of looms, as they are very straight and smooth. A flowering specimen is shown in Plate XXXII.

Among the other Philippine representatives of the genus are Schizostachyum palawanense (Plate XXXI), a scandent species known from Palawan and Laguna; S. hirtiflorum (Plate XXVI), a widely distributed species closely allied to and with the same growth form as S. lumampao; S. toppingii (Plate XXXIII), erect or subscandent, reported from Laguna, Rizal, and Mindoro; S. curranii (Plate XXIII), scandent, a species of higher altitudes in northern Luzon; S. luzonicum (Plate XXX), known only from Zambales; and S. fenixii (Plate XXV), reported from Abra, Cagáyan, Benguet, Ilocos Sur, and Panay, known as paua in Iloilo, and puser in Abra, Luzon, and there utilized in the manufacture of baskets. 


\section{PLANTING OF BAMBOO}

Until very recently almost no reliable information concerning the rates of growth of planted Philippine bamboo was available. For this reason, Mr. H. M. Curran and Dr. F. W. Foxworthy in 1912 started a bamboo plantation at the Division of Investigation of the Bureau of Forestry at Los Baños, Laguna, the direction of the planting being intrusted to Rangers de Mesa and Villamil. This plantation was started on a rather dry hill on steep slopes, covered with a mixture of tall grass and small second-growth trees. The material selected for planting was from shoots 1 to 2 years old or older from poorly grown plants which were overtopped and not well supplied with light, and from upper twigs. A few butts were also used. The length of cuttings was from 60 centimeters to 2 meters. The cuttings were collected 3 to 36 hours before planting, and were laid in water at the edge of a stream whenever it was not possible to plant immediately. During the time that this work was done the weather was very rainy and so there was less than the usual amount of drying out. The planting was done between August 29 and October 10, 1912. The implements employed were mattocks and heavy pointed sticks, the mattocks being used only when rocky soil was encountered or when very large pieces were to be planted. In all there were planted 1,015 cuttings of Bambusa spinosa, 145 of Bambusa vulgaris, and 105 of Gigantochloa levis. The area of the plantation was 2.2 hectares. More than half of the area was covered with a dense tangle of small trees and climbing bamboo. All of the small brush and climbing bamboo was cut, but some of the larger trees were left to shade the young plants. Where the bamboo was shaded it has done better than it has in the open. This may perhaps be due to the fact that the planting was done toward the end of the rainy season so that the young shoots were exposed to dryer conditions than they would have been if planted earlier.

On January 10, 1914, the living bamboos were counted; these included 349 individuals of Bambusa spinosa or 34 per cent of the original number planted, 46 of $B$. vulgaris or 32 per cent, and 6 of Gigantochloa levis or 6 per cent. This low percentage of success was probably due in part to several avoidable causes. The planting was done toward the close of the rainy season, so that young plants did not have as favorable moisture conditions as they would have had if planted earlier. Again the methods of planting, as previously described, were not favorable, while some of the young plants are known to have been destroyed by cattle; moreover, the selection of material was poor, and the 
site unfavorable. The best material for planting is from stumps, which, though harder to prepare, will probably be cheapest in the long run. Small twigs are much harder to handle than larger pieces. The cutting should be planted oblique to the ground. Planting material should be taken from full size shoots which are not fully mature. Subsequent careful planting of small numbers of these same bamboos in the early part of the rainy season gave 100 per cent success.

During the year 1914, blanks in the plantation were filled.

Bamboo cuttings, at first, send up thin whiplike shoots and it is only after a considerable period that regular culms are produced. The number and size of these culms increases yearly until mature size is reached.

In Table 1, from a report by Ranger Oro, is given a summary of the height of the culms in December, 1915; from this table, it will be seen that in three years some of the culms had reached a height of from 8 to 9 meters, but that most of them were much smaller than this.

TABLE 1.-Heights of bamboo clumps at Division of Investigation, Bureau of Forestry, Los Baños, Laguna, P. I., December, 1915, three years after planting.

[The figures in the table give the number of clumps.]

\begin{tabular}{|c|c|c|c|c|c|c|c|c|}
\hline \multirow{2}{*}{ Species. } & \multicolumn{8}{|c|}{ Height in meters. } \\
\hline & $\begin{array}{c}\text { Less } \\
\text { than } 2 .\end{array}$ & $2-3$ & $3-4$. & $4-5$ & $5-6$ & $6-7$. & $7-8$ & $8-9$. \\
\hline Bambusa spinosa & 85 & 59 & 65 & 27 & 16 & 13 & 10 & 10 \\
\hline Bambusa vulgaris & 11 & 12 & 12 & 6 & 3 & 1 & 1 & 1 \\
\hline Gigantochloa levis ... & $\ldots$ & 1 & 1 & 2 & & $\ldots$ & 1 & 2 \\
\hline
\end{tabular}

In Table 2, also from a report by Ranger Oro, is given a summary of the height of the clumps and the diameter of the canes in October, 1917. It will be seen that, five years after the original planting, most of the culms were still small, but 26. clumps of Bambusa spinosa, one of B. vulgaris and one of Gigantochloa levis were between 13 and 15 meters in height and seven of Bambusa spinosa over 15 meters in height. Bambusa spinosa had produced 80 culms, 7 centimeters in diameter; 71, 8 centimeters; 29, 9 centimeters; and 17, 10 centimeters in diameter; while Gigantochloa levis had produced 3 culms, 11 centimeters in diameter. The culms of Bambusa vulgaris were smaller, the largest being 8 centimeters in diameter. These figures show that in five years, the planted bamboo had produced some usable culms; and, judging from the difference in the 
size of the bamboo in 1915 and 1917, it may be predicted that a considerable number of usable canes would be produced in another two years.

TABLE 2.-Heights of bamboo clumps and diameters of canes at Division of Investigation, Bureau of Forestry, Los Baños, Laguna, P. I., October, 1917, five years after planting.

[Figures represent number of clumps.]

\begin{tabular}{|c|c|c|c|c|c|c|c|c|c|}
\hline \multirow{2}{*}{ Species. } & \multicolumn{9}{|c|}{ Height of clumps in meters, October, 1917.} \\
\hline & $\begin{array}{l}\text { Less } \\
\text { than } 1 .\end{array}$ & 1-3. & $3-5$ & 5-7. & 7-9. & 9-11. & 11-13. & $13-15$ & $15-17$ \\
\hline Bambusa spinosa & 2 & 26 & 24 & 32 & 53 & 55 & 44 & 26 & 7 \\
\hline Bambusa vulgaris_. & 1 & 6 & 8 & 5 & 7 & 5 & 7 & 1 & \\
\hline Gigantochloa levis & --. & - & ...... & 1 & 1 & 1 & 3 & 1 & \\
\hline
\end{tabular}

[Figures represent number of canes.]

\begin{tabular}{|c|c|c|c|c|c|c|c|c|}
\hline \multirow{2}{*}{ Species. } & \multicolumn{8}{|c|}{$\begin{array}{l}\text { Diameter of canes in centimeters, } \\
\text { October, } 1917 .\end{array}$} \\
\hline & $\begin{array}{l}\text { Less } \\
\text { than } 5 .\end{array}$ & 5. & 6. & 7. & 8. & 9. & 10. & 11. \\
\hline Bambusa spinosa..- & 994 & 150 & 97 & 80 & 71 & 29 & 17 & -.... \\
\hline Bambusa vulgaris .... & 153 & 11 & 10 & 5 & 4 & ---- & $-\cdots$ & \\
\hline Gigantochloa levis..... & 33 & 11 & 8 & 3 & 4 & 2 & 2 & 3 \\
\hline
\end{tabular}

In Table 3 is given a summary of the number of cuttings planted in 1912 and the condition of the plantation at subsequent dates.

TABLE 3.-Summary of bamboo cuttings planted at Division of Investigation, Bureau of Forestry, Los Baños, Laguna, P. I., in 1912, and condition of plantation at subsequent dates.

Summary.

Number of cuttings planted in 1912

\begin{tabular}{|c|c|c|}
\hline \multicolumn{3}{|c|}{ Species. } \\
\hline $\begin{array}{l}\text { Bambusa } \\
\text { spinosa. }\end{array}$ & $\begin{array}{l}\text { Bambusa } \\
\text { vulgaris. }\end{array}$ & $\begin{array}{c}\text { Gigan- } \\
\text { tochloa. } \\
\text { levis. }\end{array}$ \\
\hline 1,015 & 145 & 105 \\
\hline 349 & 46 & 6 \\
\hline 34.38 & 31.72 & 5.71 \\
\hline 285 & 47 & 7 \\
\hline 628 & 98 & 30 \\
\hline 3.01 & 2.81 & 5.57 \\
\hline 269 & 40 & 7 \\
\hline 1,440 & 183 & 66 \\
\hline 5.04 & 4.56 & 9.40 \\
\hline 10 & 8 & 11 \\
\hline 16.87 & 13.11 & 13.14 \\
\hline 8.51 & 6.87 & 10.40 \\
\hline
\end{tabular}

Number of clumps alive, January 10, 1914

Per cent of original planting alive, January 10, 1914

Number of clumpss, December, 1915

Total number of canes, December, 1915

Average height, December, 1915

Number of clumps, October, 1917

Total number of canes, October, 1917

Average number of canes per clump, October, 1917

Greatest diameter of canes in centimeters, October, 1917.

Greatest height in meters, October, 1817 .

Average height in October, 1917

Species. 
The area planted was 22,000 square meters. The time employed in selecting cuttings was 200 hours, in clearing 207 hours, and in planting 140 hours, making a total of 547 hours. Assuming labor at 10 centavos per hour, the cost of planting would be 25 pesos per hectare, planting being at intervals of 2 to 3 meters. During the first four years the plantation was cleaned twice a year, which included the cutting back of vines and felling and pruning of trees. This was done at a cost of about 10 pesos per hectare, per year, with labor at 10 centavos per hour.

A second bamboo plantation was started by Dr. F. W. Foxworthy at the Division of Investigation, Bureau of Forestry, at Los Baños, during June, 1917. This plantation covered 2 hectares and was planted with a single species, Bambusa spinosa. The planting was done in the months of June and July during the early part of the rainy season. The ground was covered largely with small trees and climbing bamboos, there being very little grass. The climbing bamboos were cut, but the trees left standing. The planting was done with stump and stem cuttings. The stump cuttings used had roots and were about a third of a meter in length. They were planted either in a slanting position or erect. A stem cutting consisted of a segment with a node at either end. A slit was made in the internode, and then the whole segment buried in the ground, except that the slit was left uncovered to permit water being poured into the internode. In all there were planted 225 stump cuttings and 800 stem cuttings.

All of the living shoots were counted and measured during December, 1917, and again at the end of June, 1918, when the plants were about a year old. The results of the measurements are given in Table 4 . An examination of Table 4 shows that at the end of the year 59 per cent of the stump cuttings and 40 per cent of the stem cuttings were alive. A comparison of these figures with those given in Table 3 indicates a greater percentage of success in the second than in the first plantation.

TABLE 4.-Record of plantation of Bambusa spinosa at Division of Investigation, Bureau of Forestry, Los Baños, Philippine Islands.

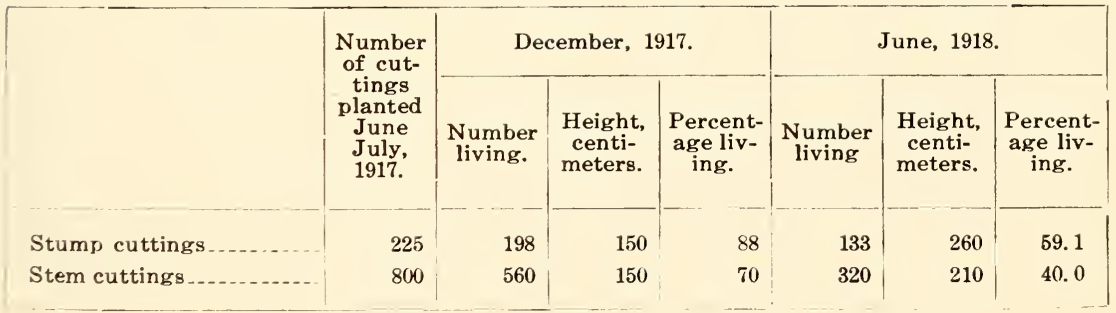


There is, however, reason to believe that much better results than those recorded in Table 4 could be obtained as the dry season of 1918 was unusually severe and the plants were not irrigated. It will be noticed that there was a high percentage of mortality between December, 1917, and June, 1918. Moreover, many of the plants were probably subjected to too much shade, as they were freed from vines only once during the year and in general those plants which survived received more light than those which died.

The total cost of selecting, transporting, and planting the cuttings were 72.82 pesos per thousand. This cost was considerably more than in the case of the 1912 plantation, which is accounted for by the greater care used in the selection of cuttings for the second than the first plantation. The superior cuttings used in 1917, however, gave much better results than the poorer ones employed in 1912.

It appears from the data derived from the planting at Los Baños that the commercial planting of bamboo on a large scale would be very profitable and that bamboo should be a valuable reforestation crop.

A number of bamboos, other than those here considered, have been propagated from hard-wood cuttings at the Division of Investigation of the Bureau of Forestry at Los Baños, and it is probable that all or most Philippine bamboos can be thus reproduced.

\section{GROWTH OF MATURE CLUMPS}

Actual measurements of growth of canes in mature clumps are available for only three species, Bambusa spinosa, Bambusa vulgaris, and Gigantochloa levis. A clump of Bambusa spinosa sends up yearly a number of shoots, the number in some cases being as large as 130. In clumps from which the mature canes are harvested, the number of new shoots may exceed the number left in the clump when the new culms are produced. A considerable proportion of the young shoots die before reaching maturity, many of them while still quite small. In Table 5 are given observations on the number of shoots produced by 8 clumps of Bambusa spinosa. The greatest number of canes produced by any clump recorded in Table 5 is 128 ; these grew from a clump having 49 mature canes. However, only 24, or 19 per cent of the 128 canes, reached maturity. The average of all the canes produced, by the 8 clumps, which reached maturity is 28.5 per cent. In all, the number of mature canes produced is 46.5 per cent of the total mature canes originally in the clumps. 
TABLE 5.-Number of shoots produced and yield of mature living canes from 8 clumps of Bambusa spinosa at Division of Investigation, Bureau of Forestry, Los Baños, Laguna, Philippine Islands. Data from report by Ranger Oro.

\begin{tabular}{|c|c|c|c|c|c|}
\hline \multirow{2}{*}{$\begin{array}{c}\text { Total } \\
\text { number } \\
\text { of mature } \\
\text { canes. }\end{array}$} & \multicolumn{3}{|c|}{ New shoots. } & \multirow{2}{*}{$\begin{array}{l}\text { Percent- } \\
\text { age liv- } \\
\text { ing. }\end{array}$} & \multirow{2}{*}{$\begin{array}{l}\text { Percent- } \\
\text { age yield. }\end{array}$} \\
\hline & $\begin{array}{c}\text { Total } \\
\text { number } \\
\text { of shoots. }\end{array}$ & $\begin{array}{c}\text { Total } \\
\text { number } \\
\text { of dead. }\end{array}$ & $\begin{array}{c}\text { Total } \\
\text { number } \\
\text { of living. }\end{array}$ & & \\
\hline 39 & 78 & 58 & 20 & 25.5 & 51 \\
\hline 24 & 29 & 24 & 5 & 17.5 & 21 \\
\hline 18 & 20 & 10 & 10 & 50 & 55.5 \\
\hline 21 & 30 & 22 & 8 & 26.5 & 38 \\
\hline 8 & 12 & 9 & 3 & 25 & 37.5 \\
\hline 13 & 34 & 25 & 9 & 26.5 & 69 \\
\hline 31 & 35 & 19 & 16 & 45.5 & 51.5 \\
\hline 49 & 128 & 104 & 24 & 19 & 49 \\
\hline \multicolumn{4}{|c|}{ Average } & 28.5 & 46.5 \\
\hline
\end{tabular}

Observations were also made on 5 clumps of Bambusa vulgaris. The results are given in Table 6. Thirty-eight per cent of the young shoots reached maturity, which is 6 per cent of the original number in the clump. Bambusa vulgaris produced fewer canes than Bambusa spinosa, but showed the same general phenomena which have just been described for Bambusa spinosa.

TABLE 6.-Number of shoots produced and yield of mature living canes from 5 clumps of Bambusa vulgaris at Division of Investigation, Bureau of Forestry, Los Baños, Laguna, Philippine Islands. Data from report by Ranger Oro.

\begin{tabular}{|c|c|c|c|c|c|}
\hline \multirow{2}{*}{$\begin{array}{c}\text { Total } \\
\text { number } \\
\text { of mature } \\
\text { canes. }\end{array}$} & \multicolumn{3}{|c|}{ New shoots. } & \multirow{2}{*}{$\begin{array}{l}\text { Percent- } \\
\text { age livi- } \\
\text { ing. }\end{array}$} & \multirow{2}{*}{$\begin{array}{l}\text { Percent- } \\
\text { age yield. }\end{array}$} \\
\hline & $\begin{array}{c}\text { Total } \\
\text { number } \\
\text { of shoots. }\end{array}$ & $\begin{array}{c}\text { Total } \\
\text { number } \\
\text { of dead. }\end{array}$ & $\begin{array}{c}\text { Total } \\
\text { number } \\
\text { of living. }\end{array}$ & & \\
\hline 48 & 48 & 34 & 14 & 29 & 29 \\
\hline 9 & 24 & 13 & 11 & 46 & 122 \\
\hline 30 & 39 & 30 & 9 & 23 & 30 \\
\hline 22 & 20 & 12 & 8 & 40 & 36 \\
\hline 44 & 52 & 25 & 27 & 52 & 61 \\
\hline $\mathrm{Av}$ & re & & & 38 & 56 \\
\hline
\end{tabular}

Gigantochloa levis also produces a very large number of new shoots, many of which fail to mature. Records obtained from 5 clumps of Gigantochloa levis are given in Table 7 . It will be seen from this table that 31 per cent of the new shoots reached maturity while the yield of the new culms is 54 per cent of the number originally in the clump. 
TABLE 7.-Number of shoots produced and yield of mature living canes from 5 clumps of Gigantochloa levis at Division of Investigation, Bureau of Forestry, Los Baños, Laguna, Philippine Islands. Data from report by Ranger Oro.

\begin{tabular}{|c|c|c|c|c|c|}
\hline \multirow{2}{*}{$\begin{array}{c}\text { Total } \\
\text { number } \\
\text { of } \\
\text { mature } \\
\text { canes. }\end{array}$} & \multicolumn{3}{|c|}{ New shoots. } & \multirow[b]{2}{*}{$\begin{array}{l}\text { Per- } \\
\text { centage } \\
\text { living. }\end{array}$} & \multirow[b]{2}{*}{$\begin{array}{l}\text { Per- } \\
\text { centage } \\
\text { yield. }\end{array}$} \\
\hline & $\begin{array}{l}\text { Total } \\
\text { number } \\
\text { of } \\
\text { shoots. }\end{array}$ & $\begin{array}{c}\text { Total } \\
\text { number } \\
\text { of } \\
\text { dead. }\end{array}$ & $\begin{array}{c}\text { Total } \\
\text { number } \\
\text { of } \\
\text { living. }\end{array}$ & & \\
\hline 22 & 36 & 25 & 11 & 31 & 50 \\
\hline 16 & 39 & 27 & 12 & 31 & 75 \\
\hline 12 & 26 & 19 & 7 & 27 & 58.5 \\
\hline 10 & 14 & 10 & 4 & 28 & 40 \\
\hline 60 & 72 & 45 & 27 & 37.5 & 45 \\
\hline Ave & re & & & 31 & 54 \\
\hline
\end{tabular}

The death of the young shoots is due to various causes; some of them are attacked by insects or rats; others are broken by the wind; while still others die without any very apparent reason, but probably because under the existing conditions more shoots are produced than can be matured by the clump. This may be due to scarcity of food, water or other causes, but concerning this point we have no information.

The culms of Bambusa spinosa and Bambusa vulgaris start to grow during the latter part of the dry season, but make very slow growth until the rainy season. Gigantochloa levis starts to grow about the beginning of the rainy season. The period of rapid growth is in the latter part of the rainy season. Bambusa spinosa, Bambusa vulgaris, and Gigantochloa levis reach about full height in approximately five months. This means that for this period there is an average daily growth in large culms of Bambusa spinosa of about 17 centimeters, in Bambusa vulgaris of about 13 centimeters, and in Gigantochloa levis of 13 centimeters.

Beginning with 1912 and extending up to the present time, measurements of the rate of growth of bamboos have been taken by the Division of Investigation of the Bureau of Forestry at Los Baños, Laguna, by means of a measured stick. The most extensive series of measurements of large culms were made by Ranger Oro in 1915. From this series we have selected for presentation in the following tables all shoots of Bambusa spinosa which reached a height of more than 20 meters, and of Bambusa vulgaris and Gigantochloa levis which reached a height of more than 12 meters. This selection has been made so as to represent the growth of only large commercial culms.

In Table 8 are given the measurements of the rates of growth of Bambusa spinosa. The first measurement was taken on June 
5, 1915, while a considerable proportion of the canes were not measured until after this date. The height at the time of the first measurement is given in the first row of figures in the table. Each column shows the growth figures for a single culm during successive weeks, the first space in each column being for the week ending June 12 . When measurements were not started until later than June 5, the first measurement of growth is recorded lower in the column, the number of blanks appearing before the first measurement of growth indicating the number of weeks after June 5 that the first measurement was taken. It will be seen that, as is usual in the growth of plant parts, the rate is at first slow and gradually increases until it reaches a maximum, after which it decreases as the culms assume mature size. The most rapid growth usually occurs nearer the end than the beginning of the growth period and takes place in the latter part of the rainy season. Three of the shoots showed a weekly growth in excess of 3 meters; the fastest rate was 3.17 meters, or an average of 45 centimeters a day for a week.

TABLE 8.-Growth of culms of Bambusa spinosa, at Division of Investigation, Bureau of Forestry, Los Baños, Laguna, Philippine Islands. Data from report by Ranger Oro.

\begin{tabular}{|c|c|c|c|c|c|c|c|c|c|}
\hline \multicolumn{10}{|c|}{ Height in meters at first measurement. } \\
\hline .24 & .16 & .29 & .06 & .40 & .14 & .40 & .18 & .31 & .27 \\
\hline \multicolumn{10}{|c|}{ Growth in meters during successive weeks. } \\
\hline .04 & .03 & .09 & .00 & . & 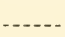 & .21 & .08 & $\therefore--$ & \\
\hline .13 & .09 & .16 & .02 & $-\ldots$ & -- & .56 & .12 & $\ldots$ & \\
\hline .13 & .09 & .20 & .03 & .21 & -...- & .84 & .14 &.-- & \\
\hline .48 & .16 & .74 & .04 & .50 & . & 1.19 & .41 & --- & \\
\hline .73 & .11 & .82 & .04 & .59 & .00 & 1.21 & .81 & .45 & .29 \\
\hline .95 & .43 & 1.35 & .11 & 1.03 & .02 & 1. 39 & 1.24 & .71 & .85 \\
\hline 1.43 & .83 & 1.81 & .15 & 1.23 & .10 & 2.48 & 1.22 & 1.11 & 1. 13 \\
\hline 1.57 & 1.10 & 2.32 & .31 & 1.68 & .54 & 2.45 & 1.68 & 1.20 & 1.51 \\
\hline 1.56 & 1.41 & 2.19 & .72 & 1.65 & .89 & 1.88 & 1. 12 & 1.72 & 1.67 \\
\hline 1.34 & 1.29 & 2.97 & .86 & 1.76 & .91 & 1.99 & 2.96 & 2.04 & 2. 76 \\
\hline 1.22 & 1.49 & 1.33 & 1.15 & 1.26 & 1.56 & 2.92 & 2.40 & 1.81 & 2.33 \\
\hline 1.37 & 1.87 & .94 & 1. 20 & 1.75 & 1.63 & 1.84 & 1.33 & 2.63 & 2. 02 \\
\hline 1.48 & 1. 73 & 1.02 & 1. 09 & 1.91 & 2.44 & 1.63 & 2.88 & 1.58 & 2. 51 \\
\hline 1.56 & 1.89 & 1.10 & 1.77 & 1.96 & 2.12 & 1.84 & 2.42 & 2.62 & 1.60 \\
\hline 1. 60 & 2.10 & 2.15 & 2.59 & 1.85 & 2.18 & 1.21 & 2.30 & 1.75 & 1.40 \\
\hline 2.85 & 2.75 & 1. 65 & 2.93 & 2.34 & 1.79 & & & i. 71 & 1.66 \\
\hline 2.44 & 2.33 & 2.02 & 3.05 & 1.54 & 2.09 & & & 1.05 & 1.57 \\
\hline 1.53 & 1.94 & 1.26 & 2.88 & .75 & 2.84 & & & .94 & 1.15 \\
\hline .71 & 1.40 & & 1.18 & & 1. 37 & & & .68 & .58 \\
\hline$-\cdots$ & .80 & & .92 & & 1.04 & & & & \\
\hline
\end{tabular}

Total height. 
TABLE 8.-Growth of culms of Bambusa spinosa, etc.-Continued.

\begin{tabular}{|c|c|c|c|c|c|c|c|c|c|}
\hline \multicolumn{10}{|c|}{ Height in meters at first measurement. } \\
\hline .32 & .23 & .44 & .39 & .35 & .27 & .24 & 1.6 & .24 & .54 \\
\hline \multicolumn{10}{|c|}{ Growth in meters during successive weeks. } \\
\hline .12 & .06 & & & ..... & .12 & .20 & .08 & .10 & \\
\hline .16 & .13 &.-- & $\cdots$ & $-\ldots$ & .17 & .22 & .15 & .20 & $\cdots$ \\
\hline .45 & .19 & .16 & .14 & .56 & .56 & .70 & .34 & .56 & .44 \\
\hline 1.00 & .70 & .50 & .20 & .98 & .94 & 1.04 & .92 & 1.01 & .97 \\
\hline 1.15 & .99 & .85 & .45 & 1.11 & 1.29 & 1.10 & .95 & 1.49 & 1.25 \\
\hline 1.73 & 1.22 & 1.07 & .77 & 1.73 & 1.49 & 1.65 & 1.56 & 1.48 & 1.43 \\
\hline 1.64 & 1.60 & 1.34 & 1.19 & 1.97 & 2.09 & 2.11 & 2.33 & 2.08 & 1.92 \\
\hline 2.09 & 1.00 & 1.64 & 1.23 & 2.35 & 2.06 & 2.51 & 1.79 & 2.13 & 2.26 \\
\hline 2.26 & 2.00 & 1.21 & 1.79 & 2.80 & 2.25 & 1.97 & 2.23 & 2.35 & 2.18 \\
\hline 3. 17 & 2.75 & 2.88 & 2.13 & 2.86 & 2.64 & 2.89 & 2.20 & 2.38 & 2.67 \\
\hline 2.49 & 2.35 & 2.24 & 1.80 & 1.98 & 2.63 & 2.91 & 2.36 & 2.76 & 2. 68 \\
\hline 1.95 & 3.07 & 2.31 & 2.65 & 2.33 & 2.43 & 2.30 & 2.58 & 2.46 & 2.94 \\
\hline 1.85 & 2.61 & 2.89 & 2.94 & 1.93 & 1.94 & 1.09 & 1.49 & 1.74 & 1.63 \\
\hline 1.58 & 2.68 & 2.03 & 2.15 & 1.11 & 1.01 & & 1.94 & 1.18 & 1.23 \\
\hline \multirow[t]{3}{*}{1.06} & 1.47 & 1.89 & 2.57 & .78 & .73 & -. & .90 & .77 & .91 \\
\hline & .96 & 1.43 & 1.72 & 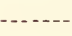 & $\ldots$ & & & $\cdots$ & \\
\hline & .... & .91 & .75 & & & & & & \\
\hline \multicolumn{10}{|c|}{ Total height. } \\
\hline 23.02 & 24.01 & 23.79 & 22.87 & 22.84 & 22.62 & 20.93 & 21.98 & 22.93 & 23.05 \\
\hline
\end{tabular}

From the table it would appear that the period of most rapid growth of any individual culm depends rather on the height of the culm than on the season.

The culms for which measurements are given in Table 8 were all large or fairly large; smaller culms show slower rates of growth, but mature in about the same length of time.

In Table 9 are given measurements of the growth of culms of Bambusa vulgaris. This table is constructed in the same manner as the previous table for Bambusa spinosa. The rates of growth are slower than those for Bambusa spinosa, as might be expected from the fact that Bambusa vulgaris is a smaller bamboo. These figures show even more clearly than do those for Bambusa spinosa that the time of most rapid growth depends more on the stage of the development of the culm than on the season. 
TABLE 9.-Growth of culms of Bambusa vulgaris, at Division of Investigation, Bureau of Forestry, Los Baños, Laguna, Philippine Islands.

Data from report by Ranger Oro.

Height in meters at first measurement.

\begin{tabular}{|c|c|c|c|c|c|c|c|c|c|c|}
\hline .10 & .17 & .20 & .14 & .45 & .12 & .18 & .12 & .16 & .03 & .05 \\
\hline \multicolumn{11}{|c|}{ Growth in meters during successive weeks. } \\
\hline & & & & .40 & .00 & & & .00 & .01 & \\
\hline & & $\cdots$ & - & .91 & .00 & $\ldots$ & - & .07 & .03 & -- \\
\hline & & $-\ldots$ & (n) & .92 & .02 & $-\ldots$ & $-\ldots$ & .00 & .04 & .12 \\
\hline - . - & & $\ldots$ & .00 & 1.34 & .00 & $\ldots$ & -...-. & .02 & .03 & .01 \\
\hline .06 & - & $\ldots$ & .00 & .96 & .00 & .04 & .04 & .06 & .02 & .08 \\
\hline .08 & .... & $\ldots$ & .09 & 1.60 & .08 & .00 & .01 & .09 & .05 & .17 \\
\hline .08 & .07 & .10 & .03 & 1.42 & .17 & .14 & .06 & .12 & .14 & .17 \\
\hline .15 & .06 & .20 & .04 & 1. 71 & .35 & .46 & .14 & .25 & .28 & .73 \\
\hline .39 & .10 & .51 & .46 & 1.41 & .26 & .56 & .24 & .16 & .98 & .93 \\
\hline .83 & .38 & .84 & .94 & 2.26 & 1.09 & 1.08 & 1.13 & .82 & .99 & .97 \\
\hline 1.04 & .89 & 1.05 & 1.29 & 1.28 & 1.20 & 1.11 & 1.56 & 1.06 & 1.01 & .72 \\
\hline 1.11 & .94 & 1.01 & 1.26 & .19 & 1.20 & 1. 12 & 1.38 & 1.00 & 1.08 & .85 \\
\hline 150 & 1.32 & 1.37 & 1.30 & .17 & 1.14 & 1.12 & 1.19 & .79 & .65 & 1.04 \\
\hline 1.56 & .72 & .82 & .81 & .14 & 1.24 & .91 & 1. 63 & .94 & 1.26 & .98 \\
\hline .58 & 1.43 & 1.40 & 1.49 & .14 & 1.68 & 1.85 & 1.40 & 1.36 & 1.25 & 1.20 \\
\hline 1.07 & 1.22 & 1.42 & 2.10 & & 1.43 & 1.53 & 1.80 & 1.35 & 2.02 & 1.21 \\
\hline 1.55 & 1.75 & 1.78 & 1.60 & & 1.52 & 1.30 & 1.40 & 1.65 & 1.05 & 1.32 \\
\hline .45 & 1.70 & 1.80 & .35 & & 1.15 & 1.25 & 1.00 & .90 & .98 & .85 \\
\hline 1.70 & 1.35 & 1. 05 & .23 & & .85 & 1.25 & 1.80 & .70 & 1.35 & .65 \\
\hline 1.36 & 1.00 & 1.04 & & & .92 & .91 & .50 & .65 & & \\
\hline .94 & .92 & 1. 01 & & & & & .15 & .20 & & \\
\hline .40 & .62 & .49 & & & & & & & & \\
\hline .23 & .41 & .29 & & & & & & & & \\
\hline \multicolumn{11}{|c|}{ Total heights. } \\
\hline 16.18 & 15.05 & 16.38 & 12.13 & 15.30 & 14.42 & 14.81 & 15.55 & 12.35 & 13. 25 & 12.05 \\
\hline
\end{tabular}

Measurements of growth of culms of Gigantochloa levis are given in Table 10. This species sends up its shoots in general later than do Bambusa spinosa and Bambusa vulgaris. Measurements were started on a few shoots which had commenced to develop on June 5, but only one of these shoots reached maturity and then produced only a small culm. The measurements of this individual have not been included in our table on account of the small size attained. In general the shoots did not commence to develop in 1915 until July. The date of the first 
measurements of culms given in Table 9 is July 3. Except for the later development of the culms, Gigantochloa levis shows the same general growth phenomena as Bambusa spinosa and Bambusa vulgaris, but the rates of growth, according to our tables, are intermediate.

TABLE 10.-Growth of culms of Gigantochloa levis, at Division of Investigation, Bureau of Forestry, Los Baños, Laguna, Philippine Islands. Data from report by Ranger Oro.

\begin{tabular}{|c|c|c|c|c|c|c|c|c|}
\hline \multicolumn{9}{|c|}{ Height in meters at first measurement. } \\
\hline .09 & .05 & .10 & .09 & .24 & .10 & .20 & .15 & .37 \\
\hline \multicolumn{9}{|c|}{ Growth in meters during successive weeks. } \\
\hline & .03 & .04 & & & & & & \\
\hline -... & .02 & .05 &.-- &.-- & $-\ldots$ & & -1 & .14 \\
\hline .08 & .05 & .07 & .08 & .12 & .01 & --- & $\ldots$ & .33 \\
\hline .07 & .02 & .11 & .11 & .16 & .03 & .13 & - & .88 \\
\hline .20 & .08 & .11 & .10 & .32 & .01 & .30 & .01 & 1.14 \\
\hline .16 & .01 & .23 & .18 & .88 & .01 & .49 & .10 & 1.80 \\
\hline .58 & .23 & .60 & .49 & 1.21 & .01 & 1. 14 & .07 & 2.04 \\
\hline .92 & .27 & 1. 13 & .92 & 1.58 & .01 & 1.69 & .14 & 1.57 \\
\hline .68 & .64 & 1.16 & 1.05 & 1.19 & .33 & 1.00 & .26 & 1. 30 \\
\hline 1. 29 & 1.12 & 1. 22 & .98 & 1.48 & .22 & 1.19 & .72 & 1.15 \\
\hline 2.73 & 1.11 & 1. 81 & 1.63 & .99 & .77 & 1.81 & 1.45 & .75 \\
\hline 1.88 & 1.01 & 1.55 & 1.90 & 2.28 & 1.30 & 1.85 & 1.55 & 1.41 \\
\hline .87 & 2.16 & 1.97 & 1.67 & 1. 20 & 1.90 & 1.57 & 2.35 & 1.09 \\
\hline 1. 75 & 2.60 & 1.65 & 1.35 & 1.35 & 2.70 & .99 & 2.10 & .63 \\
\hline 1.49 & 1.05 & 1.00 & 1.45 & .92 & 2.00 & .70 & 1.05 & \\
\hline .78 & 1.11 & $.50^{\prime}$ & .90 & .57 & 1.47 & .30 & 1.20 & \\
\hline \multirow[t]{2}{*}{.33} & .94 & .30 & .50 & .22 & .92 & .... & .95 & \\
\hline & .50 & .20 & .16 & .... & .50 & & & \\
\hline$-\cdots$ & -... & .16 & & 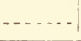 & .20 & & & \\
\hline \multicolumn{9}{|c|}{ Total heights. } \\
\hline 13.90 & 13.00 & 13.96 & 13.56 & 14.71 & 12.49 & 13.36 & 12.10 & 14.60 \\
\hline
\end{tabular}


TABLE 10.-Growth of culms of Gigantochloa levis, etc.-Continued.

\begin{tabular}{|c|c|c|c|c|c|c|c|c|}
\hline \multicolumn{9}{|c|}{ Height in meters at first measurement. } \\
\hline .21 & .22 & .23 & .72 & .24 & .22 & .31 & .11 & .13 \\
\hline \multicolumn{9}{|c|}{ Growth in meters during successive weeks. } \\
\hline 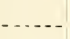 & & --- & .68 & & & & & \\
\hline .09 & --- & ..... & 1.10 &.- & --- & 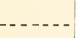 & & \\
\hline .13 &.-- & $-\ldots$ & 1.68 & .19 & .33 & -.... & 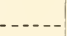 & - \\
\hline .20 & .02 & .08 & 1.60 & .10 & .74 & .57 & .11 & .02 \\
\hline .31 & .01 & .35 & 2.18 & .09 & 1.06 & .99 & .11 & .11 \\
\hline .69 & .02 & 1.16 & 1.61 & .02 & 1.41 & 1.46 & .11 & .12 \\
\hline 1.31 & .13 & 1.20 & .59 & .36 & 1.66 & 1.66 & .27 & .21 \\
\hline 1.76 & .18 & 1.90 & .50 & 1.10 & 1.38 & 2.00 & .64 & .51 \\
\hline 1.55 & .60 & 1.60 & 2.09 & 1.52 & 1.50 & 1.33 & 1.20 & 1.20 \\
\hline 2.05 & 1.17 & 1.80 & 1.20 & 2.26 & 1.90 & 1.98 & 1.17 & 1.10 \\
\hline 1.93 & 1.35 & 1.96 & .93 & 1.49 & 1.40 & 2.36 & 1.43 & 2.27 \\
\hline 2.27 & 2.00 & .77 & .12 & 2.03 & 1.15 & 1.34 & 1.66 & 2.03 \\
\hline 1.15 & 2.00 & 1.75 & -... & 1.40 & .95 & .90 & 1.49 & 1.70 \\
\hline 1.20 & 2.75 & 1.35 & & 1.30 & .60 & .70 & 1.80 & 1.20 \\
\hline .78 & 1.35 & .83 & & .93 & .50 & .30 & 1.35 & 1.20 \\
\hline .27 & 1.15 & .26 & -..- & .64 & .30 & .30 & .45 & .78 \\
\hline .... & .75 & & & & & & 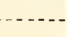 & .18 \\
\hline \multicolumn{9}{|c|}{ Total heights. } \\
\hline 15.90 & 14. 10 & 15.24 & 15.00 & 13.67 & 15.10 & 16.20 & 11.90 & 12. 76 \\
\hline
\end{tabular}

Osmaston ${ }^{1}$ found that Dendrocalamus giganteus at Dehra Dun, India, began to develop new culms toward the middle of the rainy season and that these did not complete their growth until two months after the rains normally ceased. It would appear from this that all bamboos do not behave alike in respect to their season of growth.

${ }^{1}$ Osmaston, B. B., Rate of Growth of Bamboos, Indian Forester, Vol. 44 (1918), page 52. 
Ranger Mabesa has made counts of the number of shoots produced in one season on two areas of Schizostachyum lumampao, each area consisting of 100 square meters. The two areas together contained 340 canes and produced 35 shoots, or 10 per cent of the original number. All canes were cut from two smaller-sized plots in May, 1917, and the number of new canes counted in November, 1917 . These two plots originally contained 221 canes. After the clearing they sent up a large number of shoots about the size of a lead pencil and 10 usable canes, which is only 4.5 per cent of the original number. This would indicate that it requires some years for this bamboo to regain its original density when once completely cut-over.

\section{COST OF HARVESTING AND PRICES}

Data on the cost of harvesting were collected during the year 1916 on the College of Agriculture farm at Los Baños, Laguna. One man was employed for a total of 91 days, during which time 1,000 canes of Bambusa spinosa were harvested, an average of 11 canes per day. The cost of labor was 80 centavos per day, making the total cost of harvesting 1,000 canes 72.80 pesos or an average per cane of 7.28 centavos. In the same locality these canes sold at 4 pesos per dozen.

Bamboo sold in Manila is floated down the river from the country behind or across Manila Bay. In Manila the present prices for canes in the river are: First-class canes, 32 pesos per hundred; second-class canes, 27 pesos per hundred; and third-class canes, from 18 to 20 pesos per hundred. The cost of floating bamboo to Manila is very small, as rafts containing large numbers of canes can be operated by a very few men. 


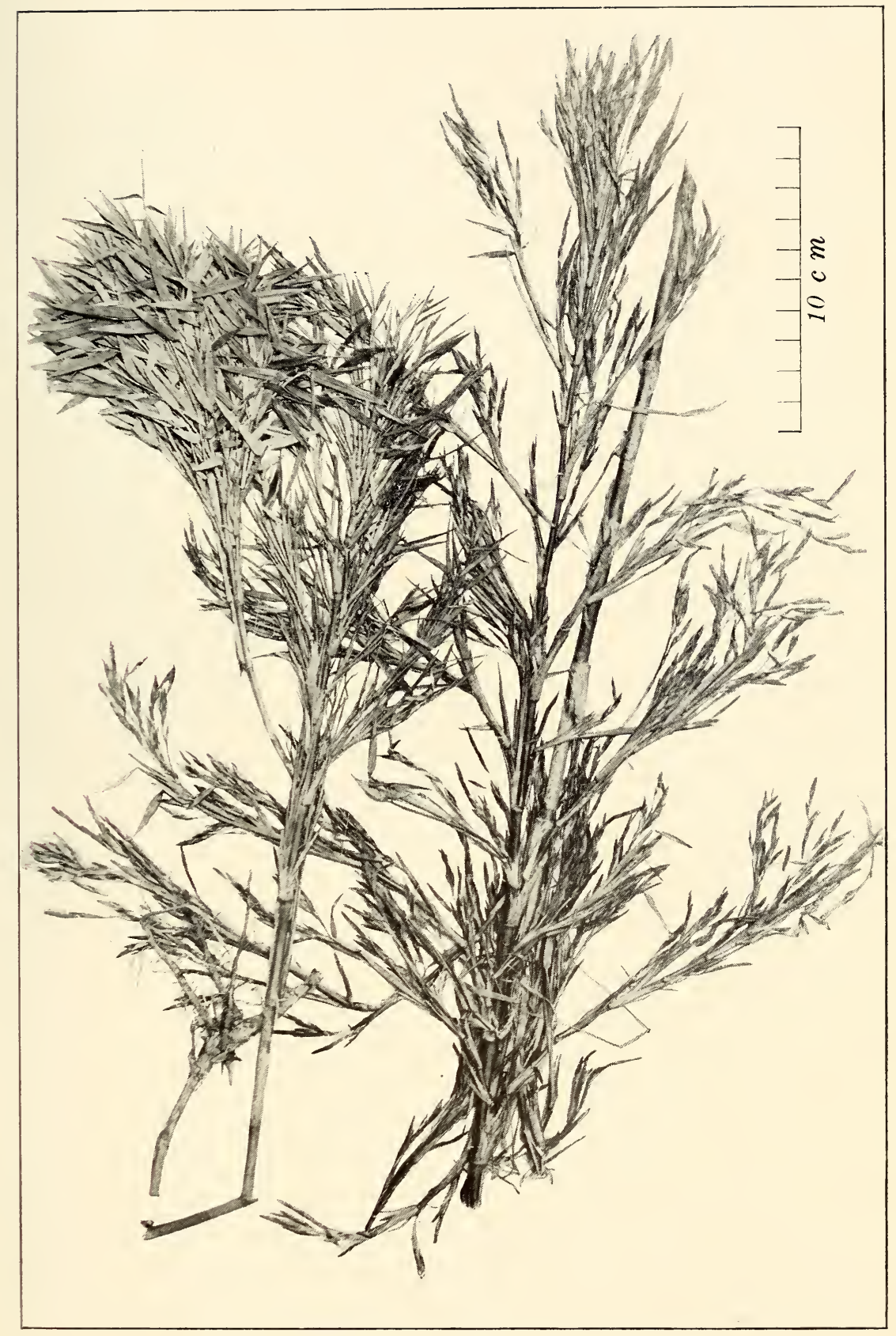

PLATE II. ARUNDINARIA NIITAKAYAMENSIS HAYATA. 


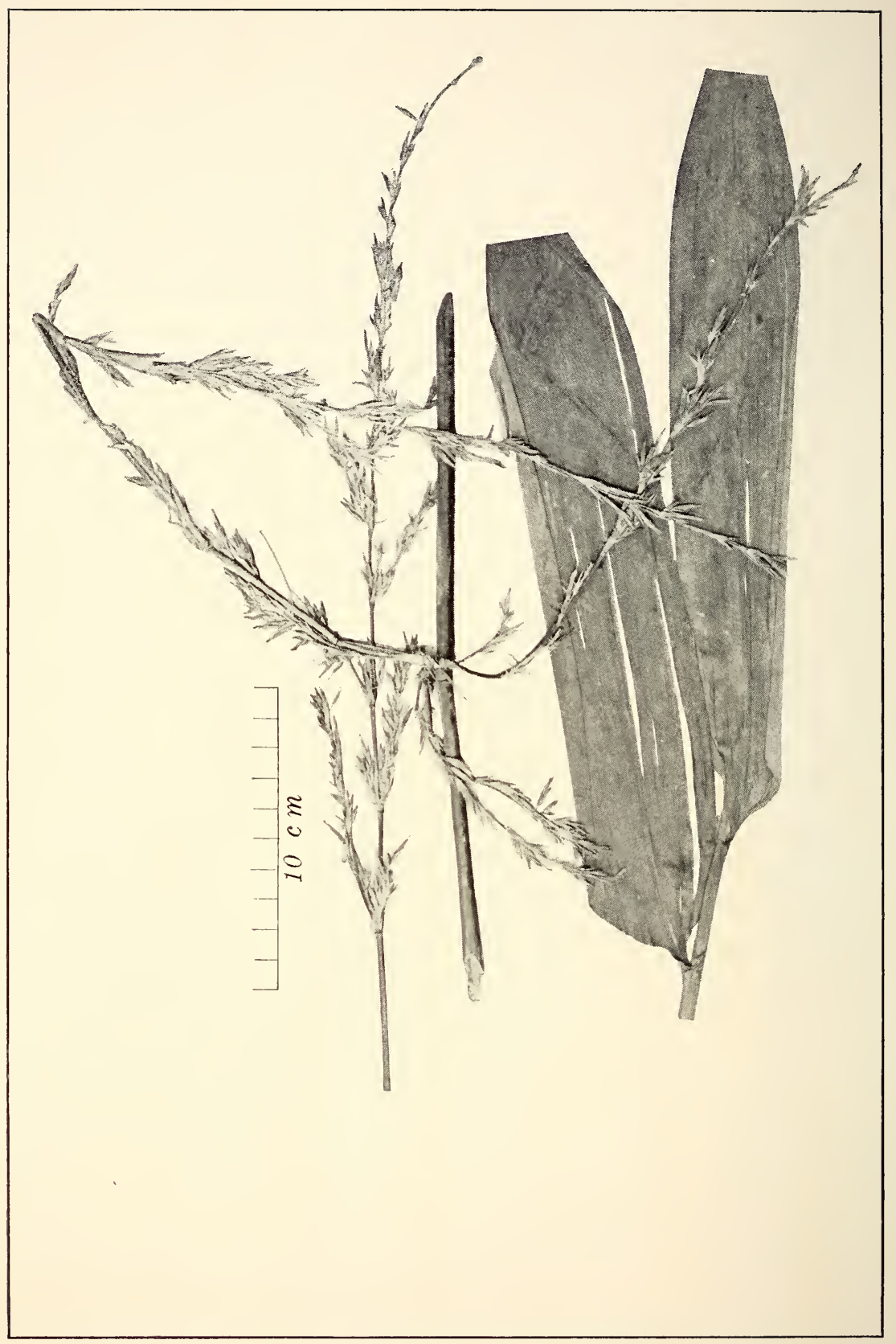

PLATE III. BAMBUSA CORNUTA MUNRO. 


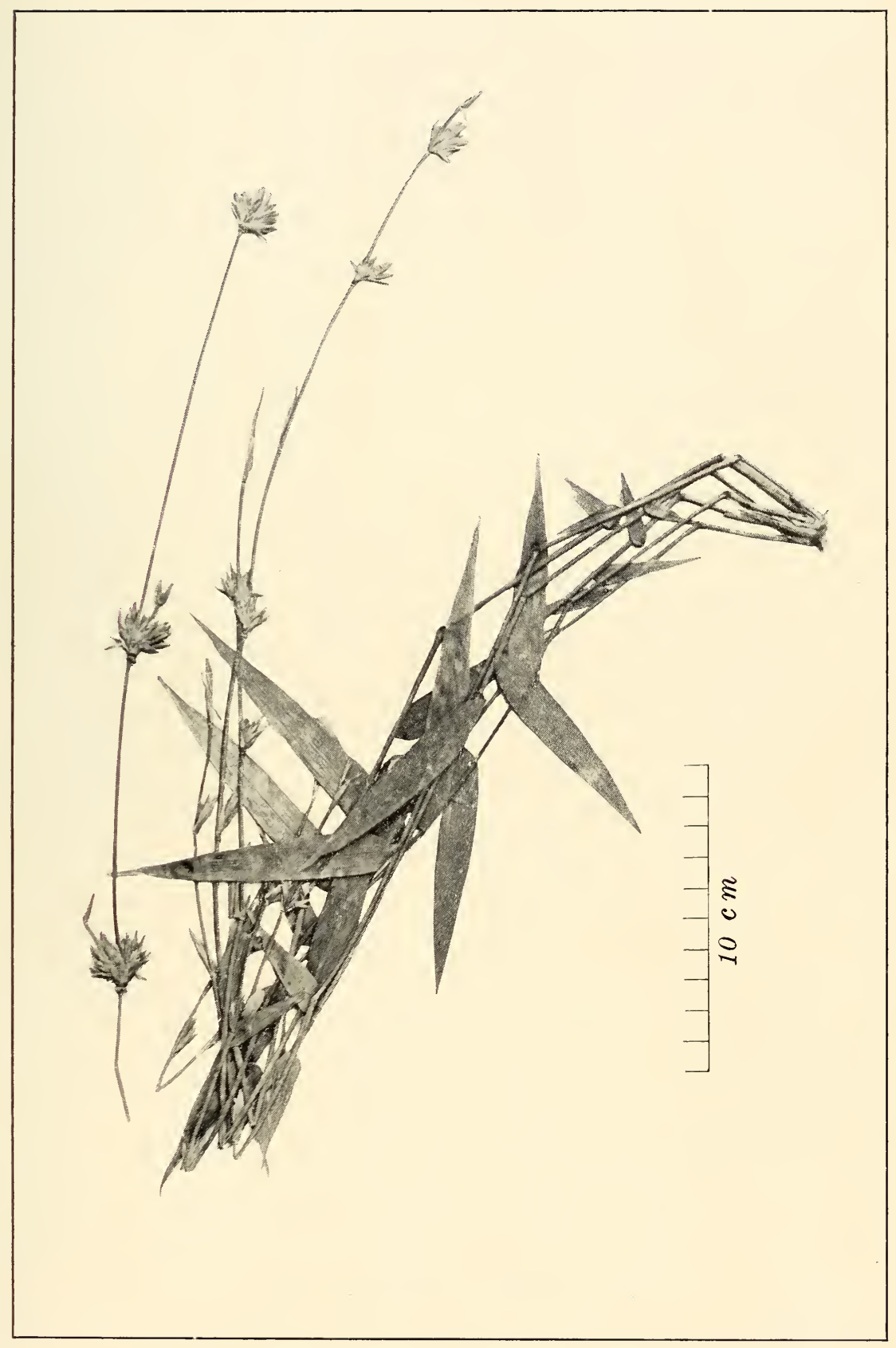

PLATE IV. BAMBUSA MERRILLII GAMBLE. TYPE SPECIMEN. 


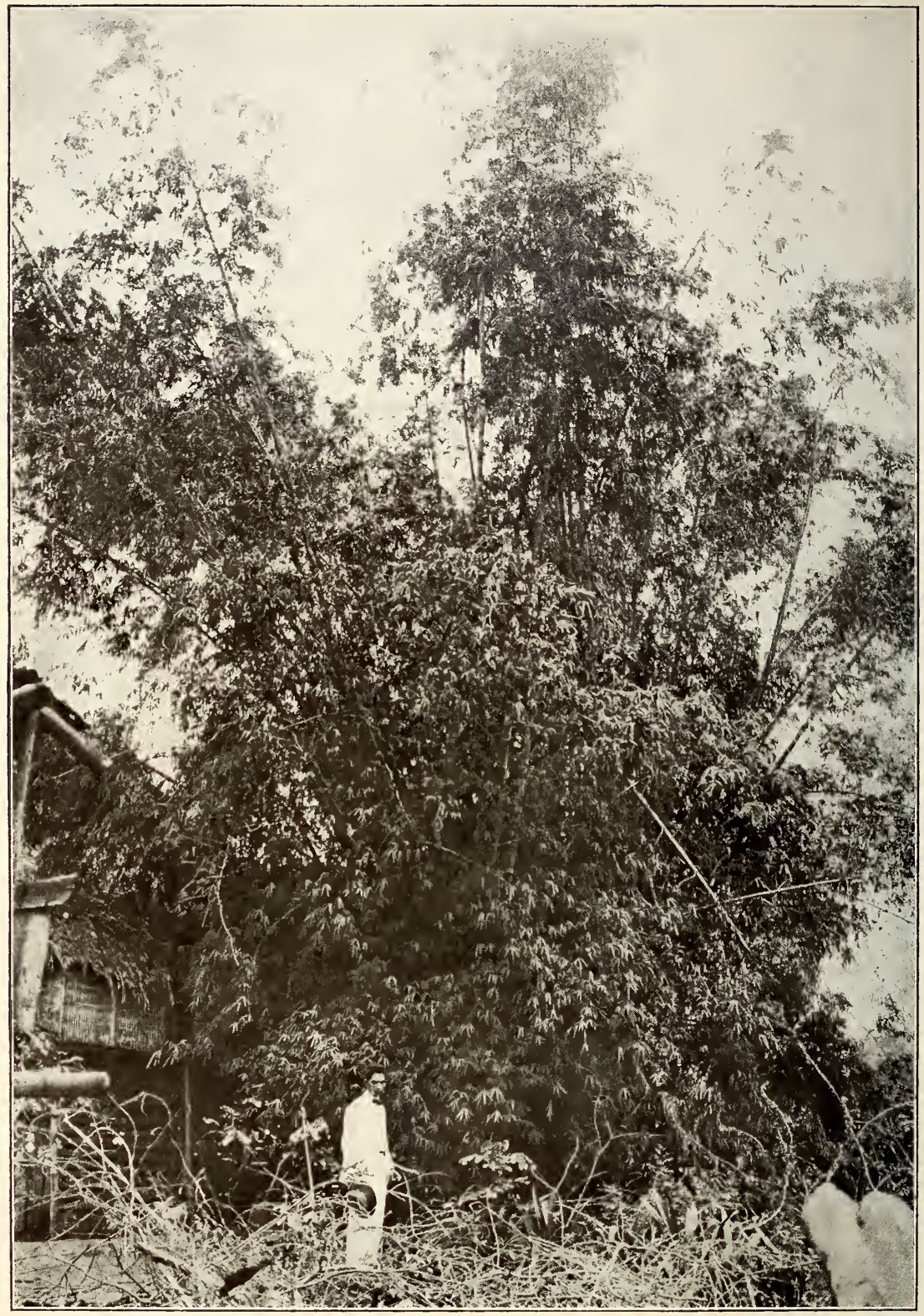

PLATE V. BAMBUSA SPINOSA ROXB. 


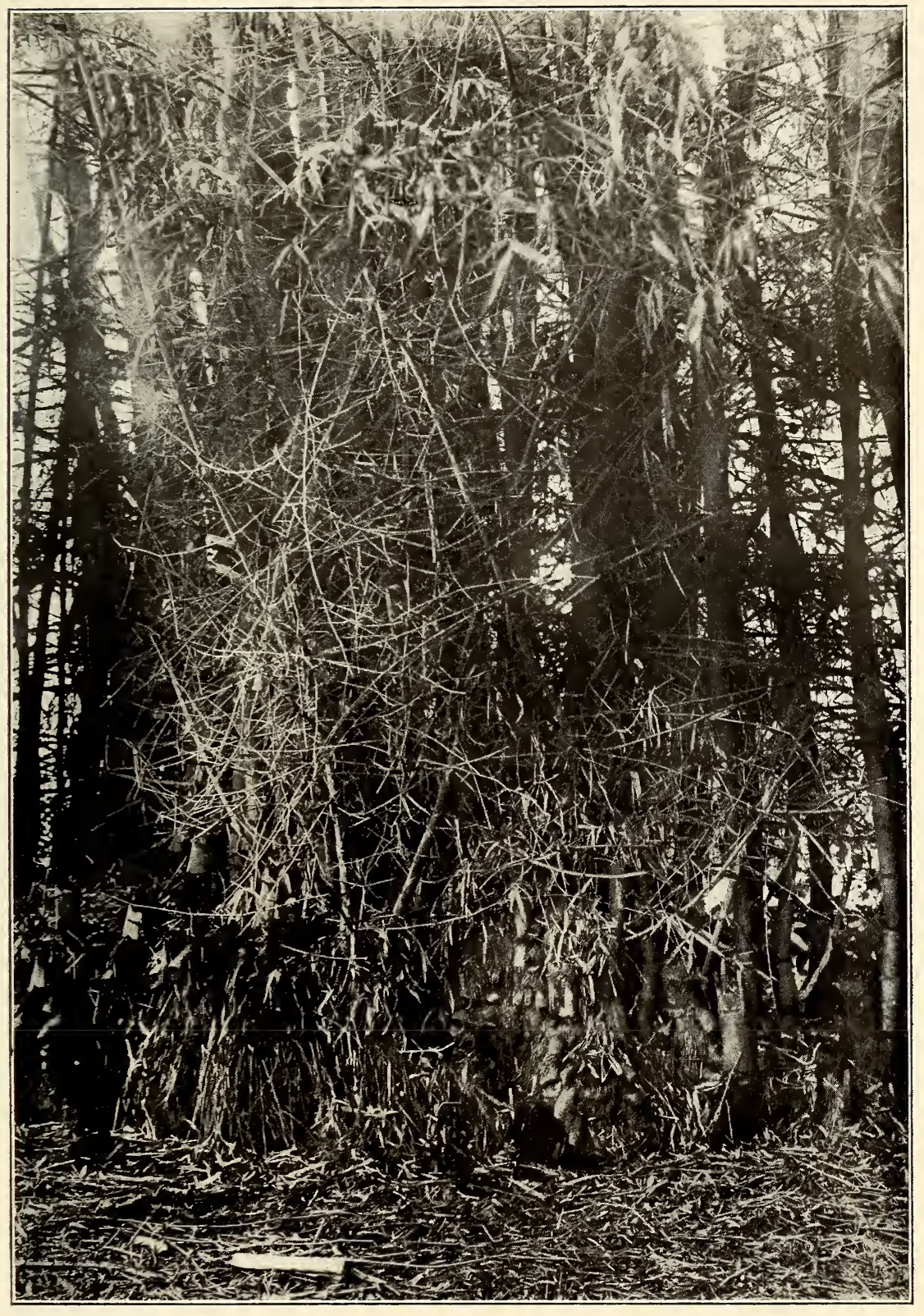

PLATE VI. BAMBUSA SPINOSA ROXB. 


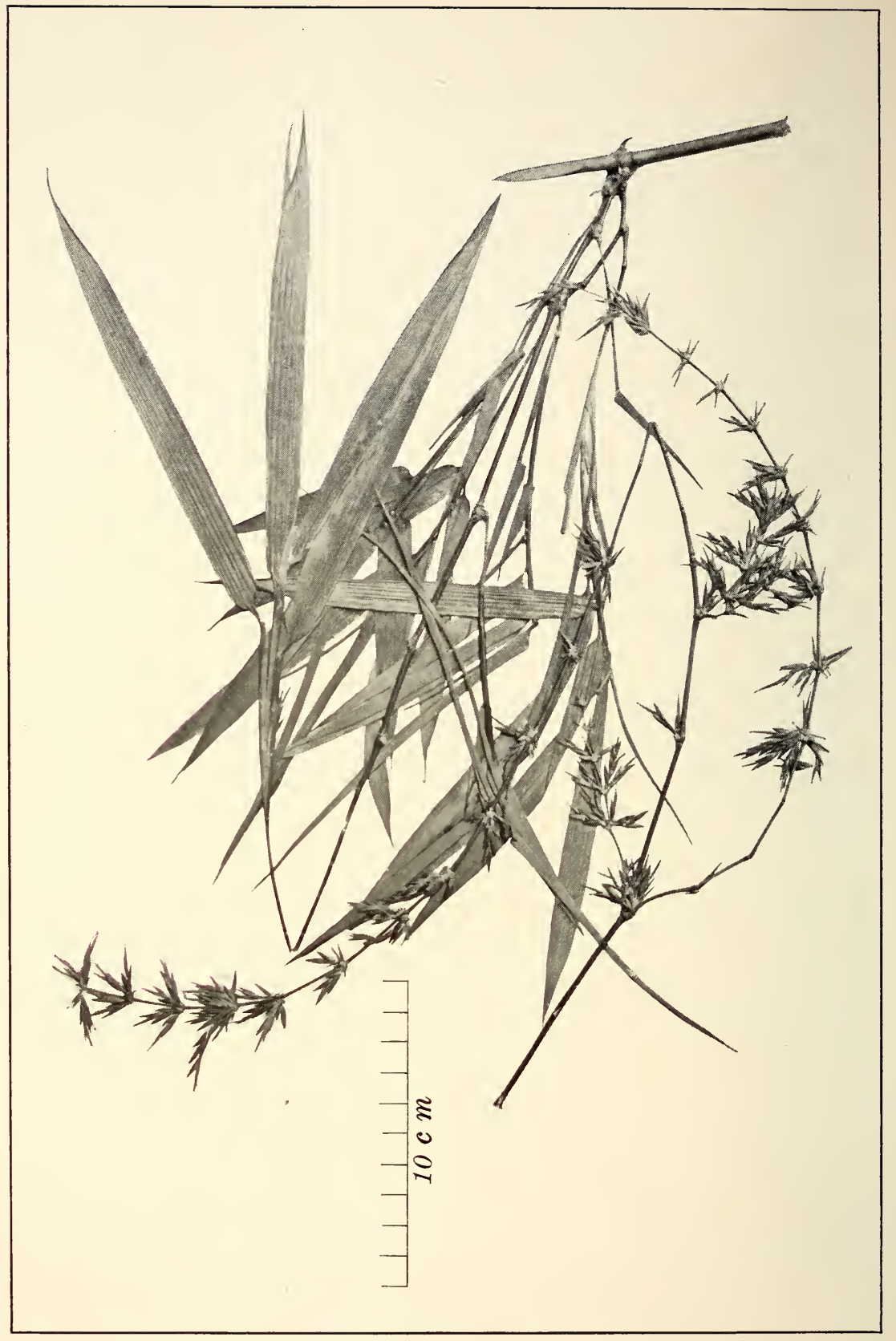

PLATE VII. BAMBUSA SPINOSA ROXB. 


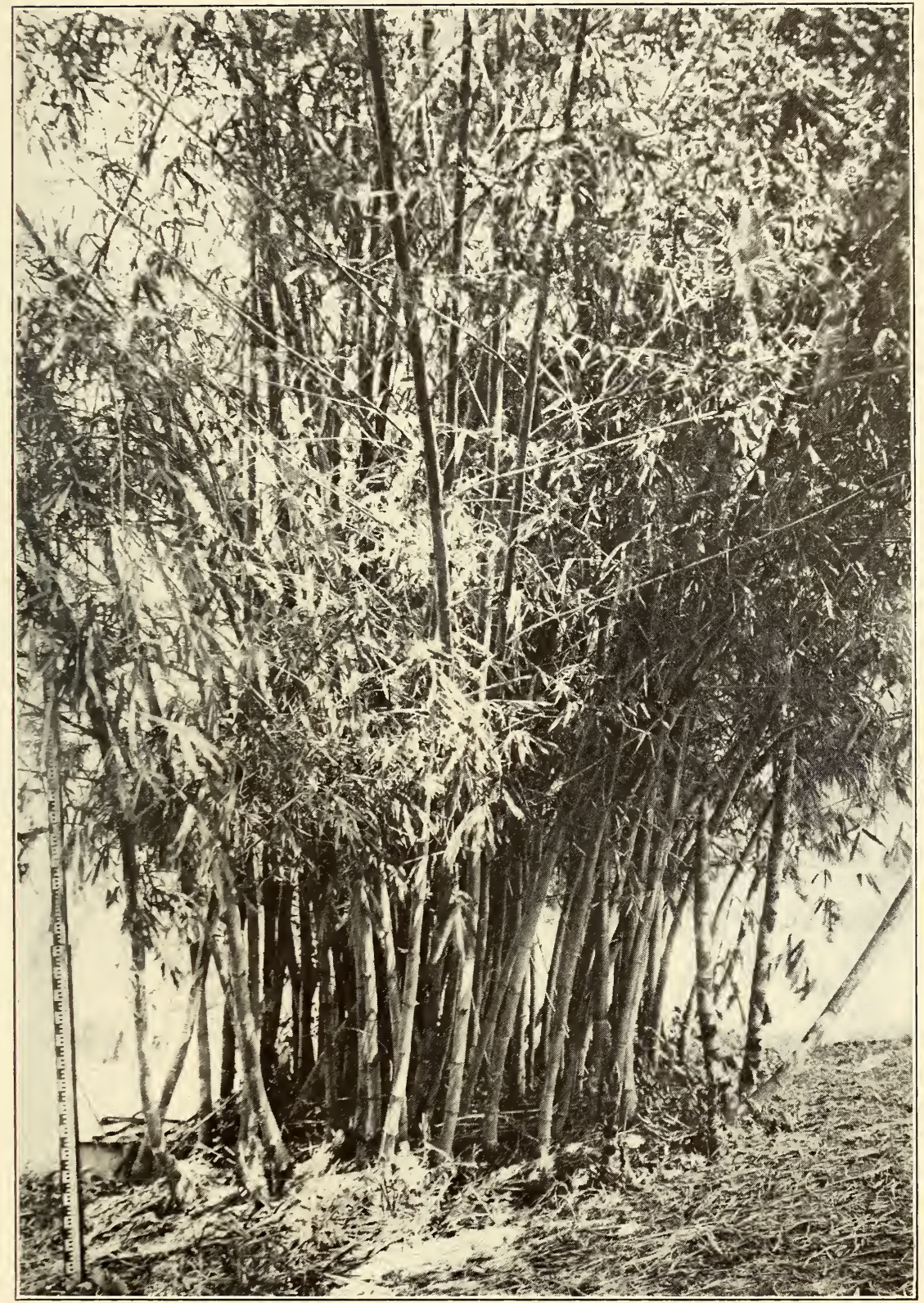

PLATE VIII. BAMBUSA VULGARIS SCHRAD. 


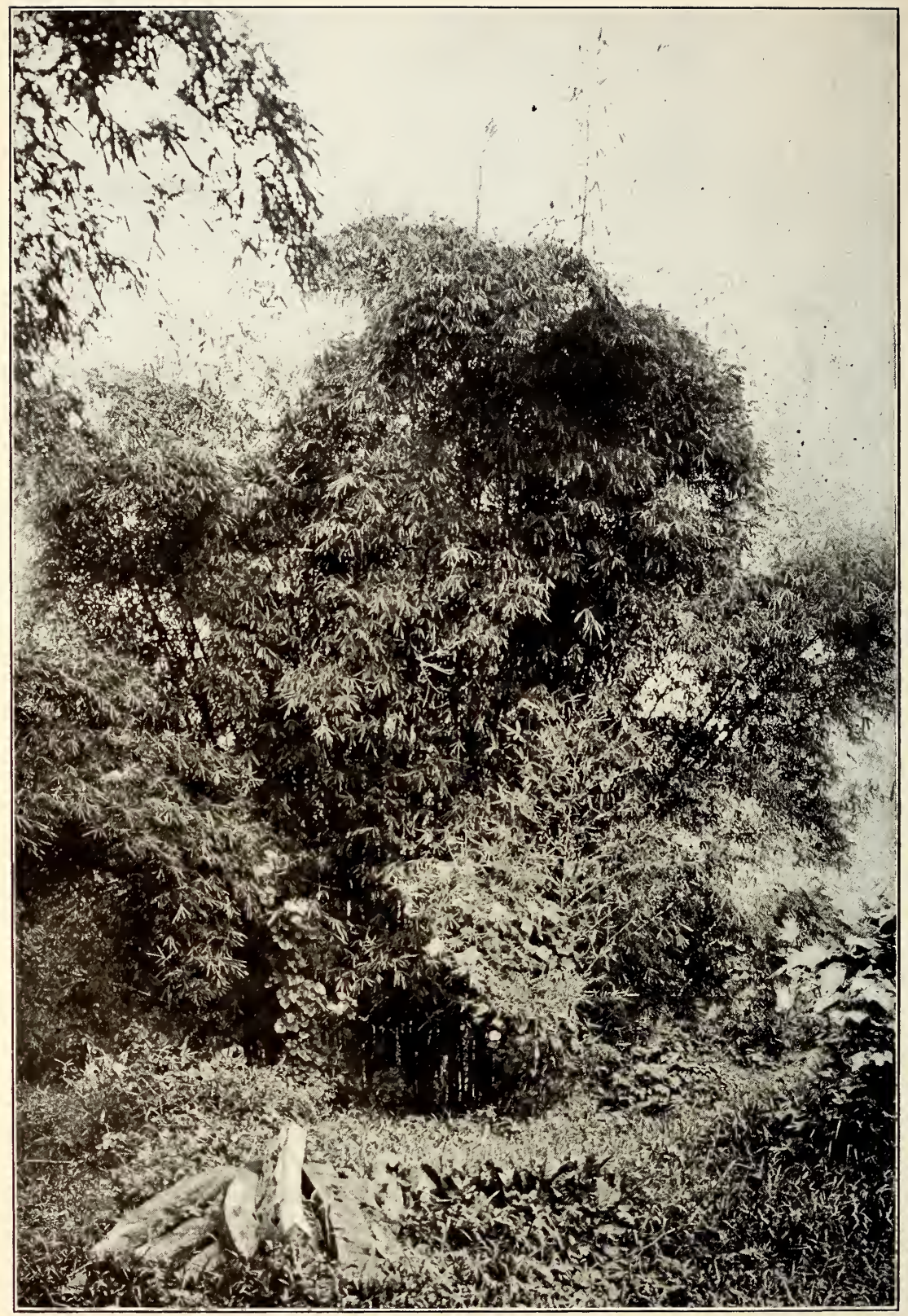

PLATE IX. BAMBUSA VULGARIS SCHRAD. 


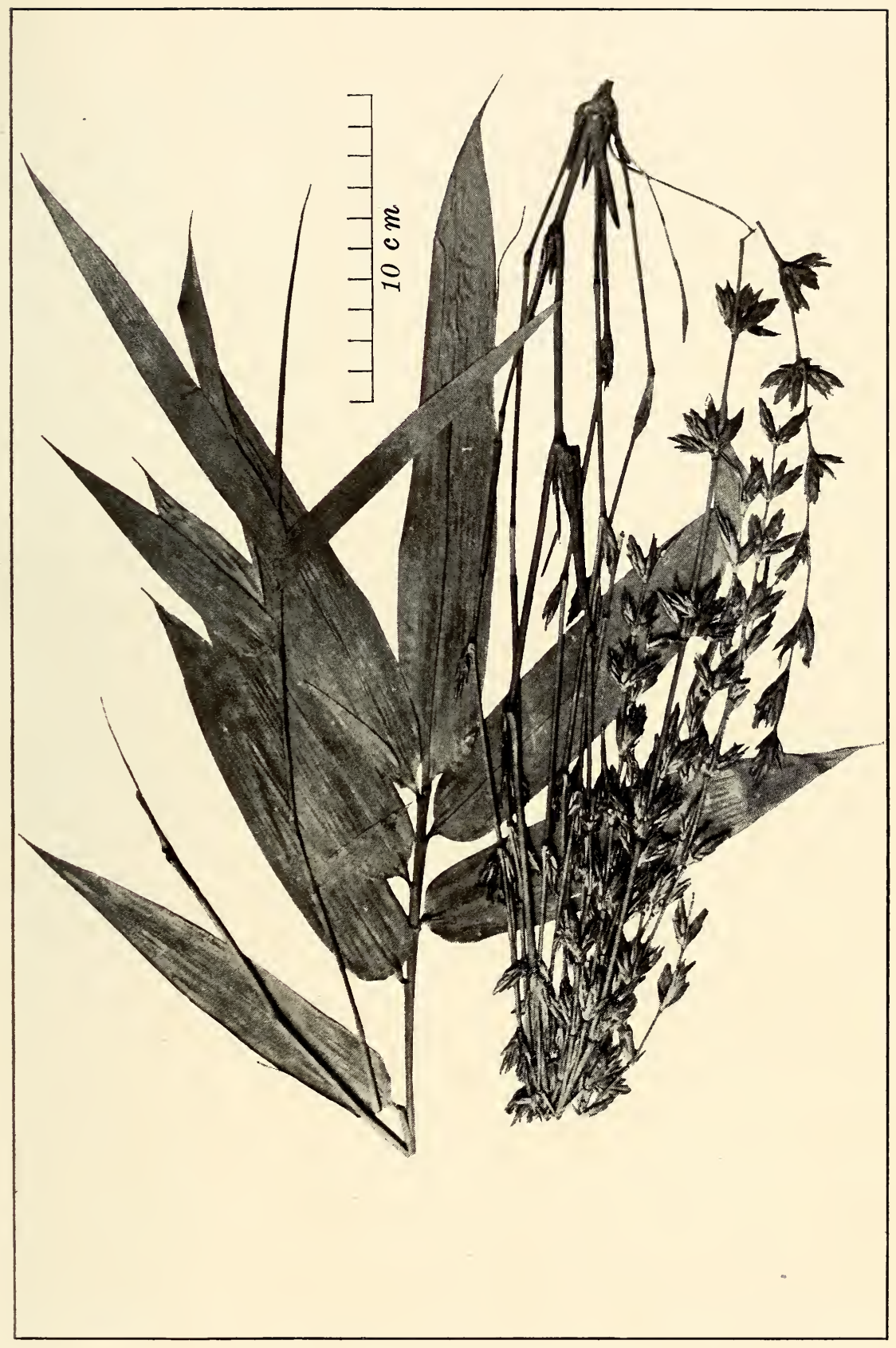

PLATE $X$. BAMBUSA VULGARIS SCHRAD. 


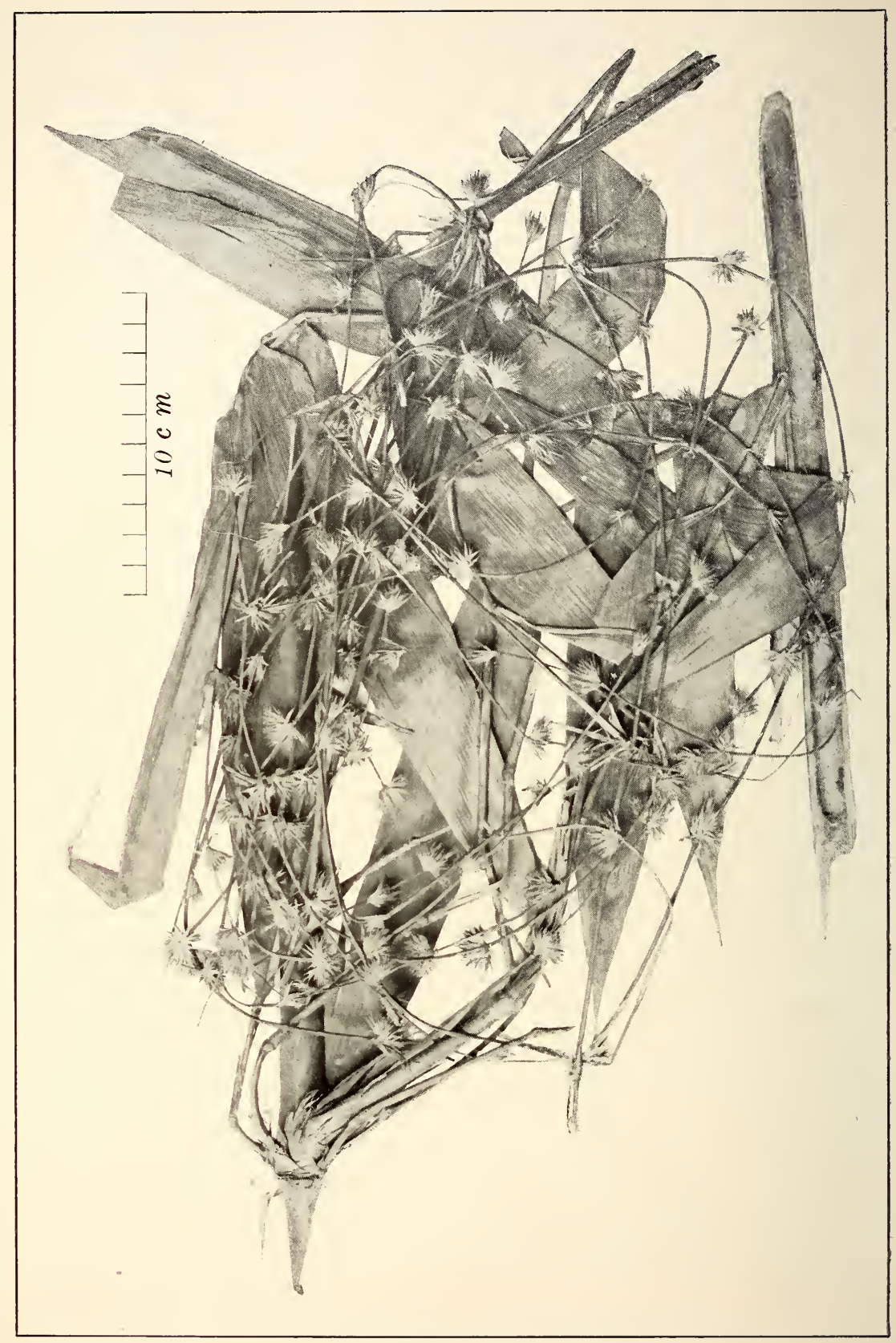

PLATE XI. CEPHALOSTACHYUM MINDORENSE GAMBLE. COTYPE SPECIMEN. 


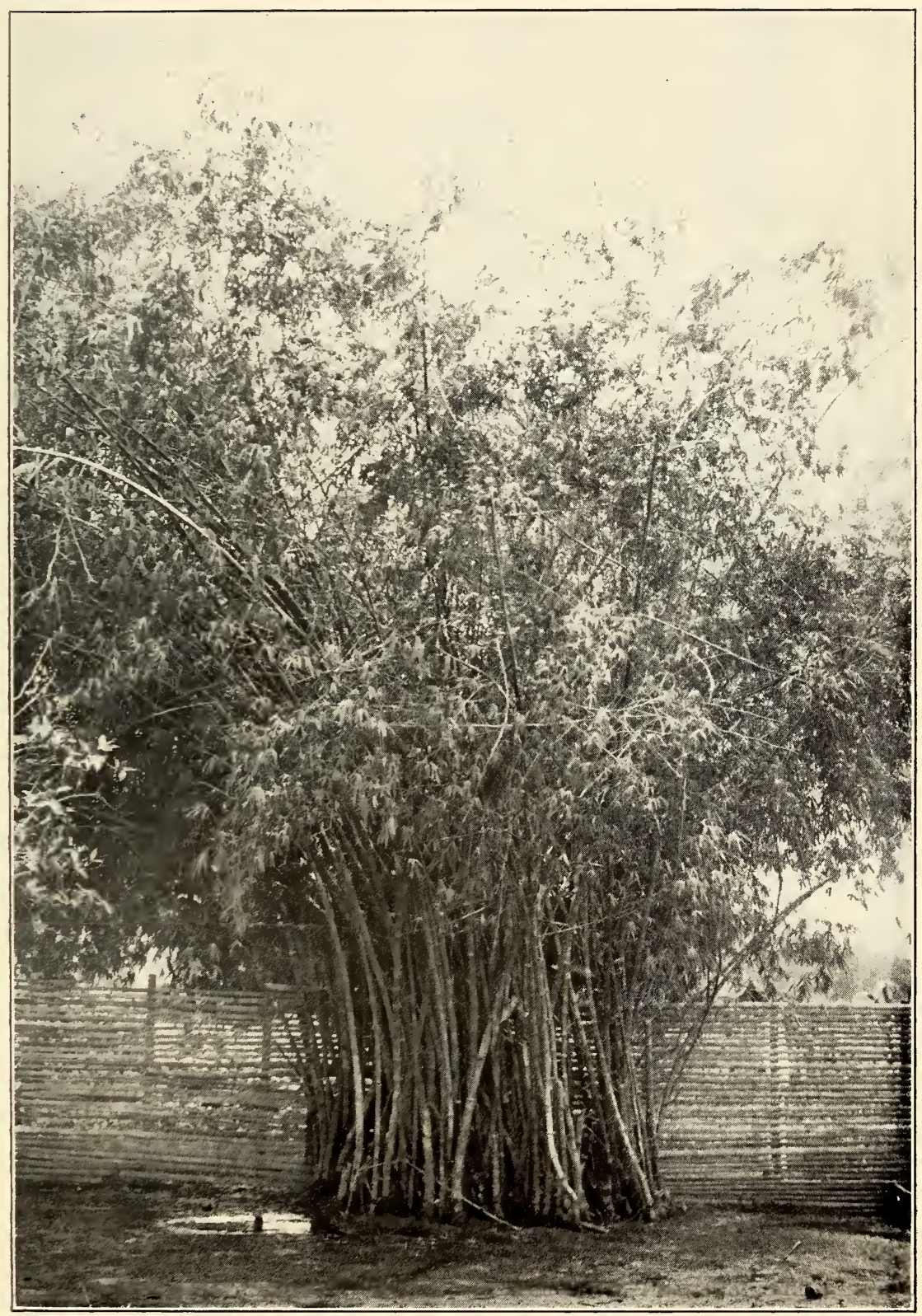

PLATE XII. DENDROCALAMUS MERRILLIANUS ELM. 


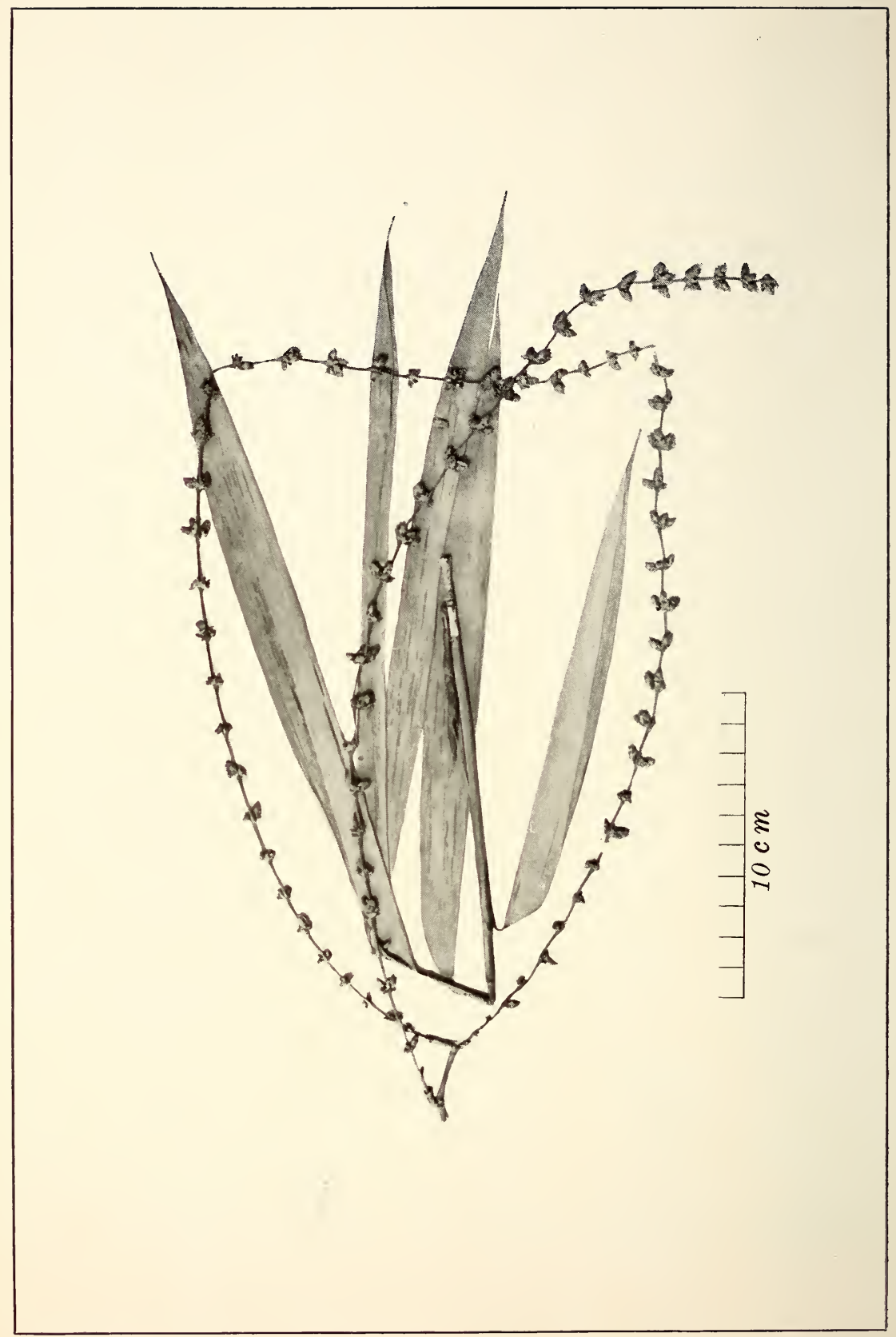

PLATE XIII. DENDROCALAMUS MERRILLIANUS ELM. COTYPE SPECIMEN. 


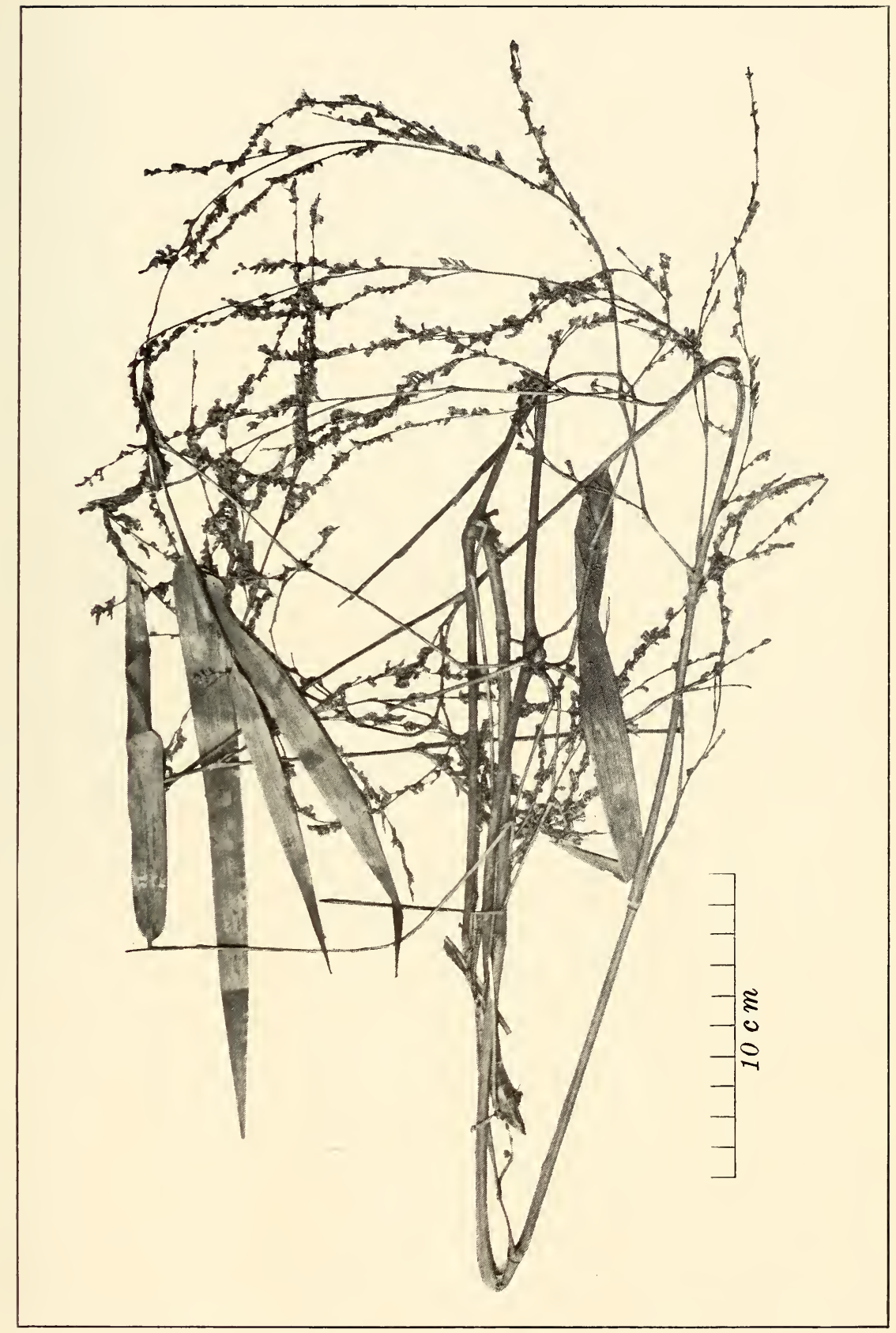

PLATE XIV. DINOCHLOA CILIATA KURZ. 


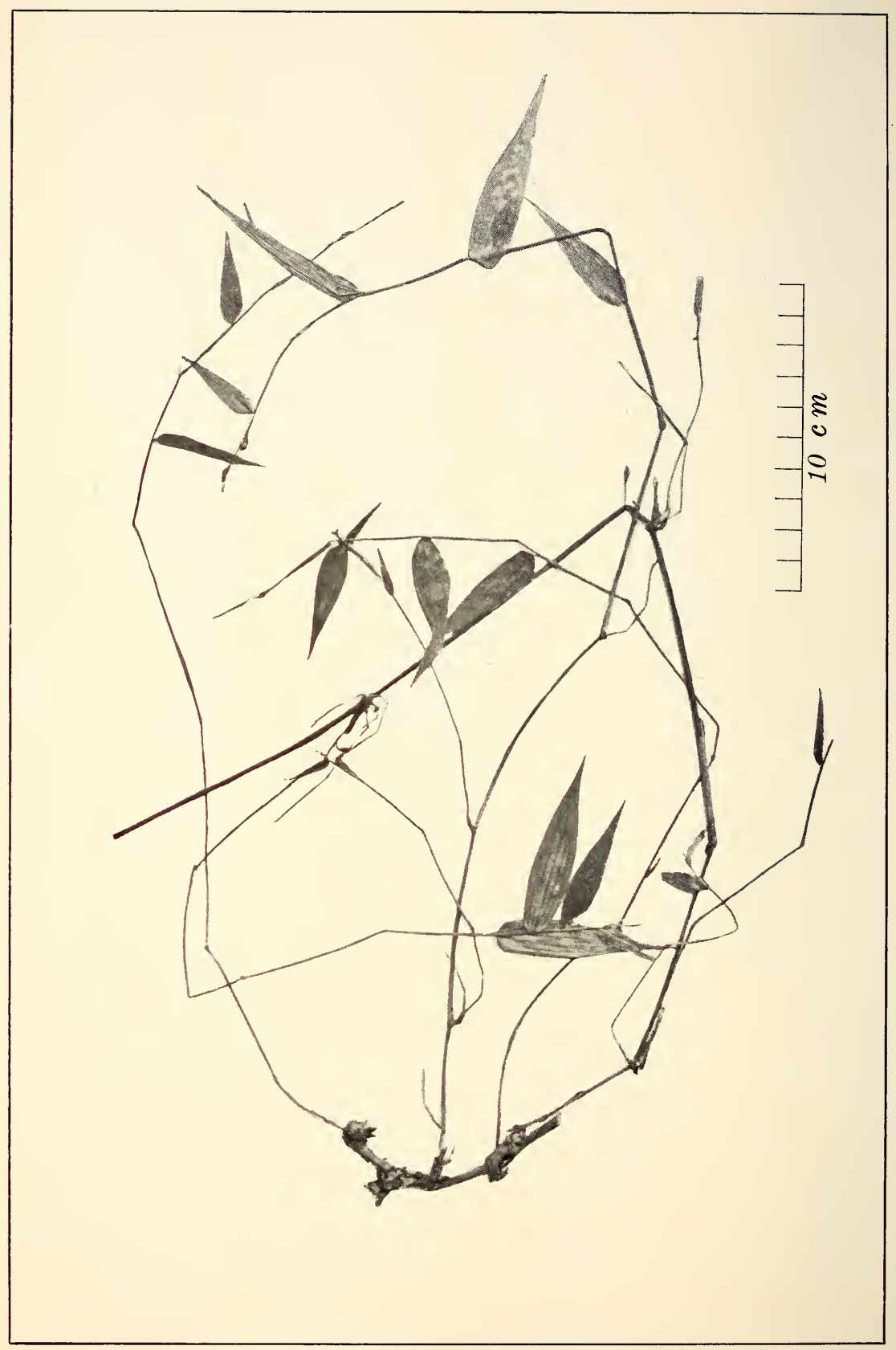

PLATE XV. DINOCHLOA ELMERI GAMBLE. 


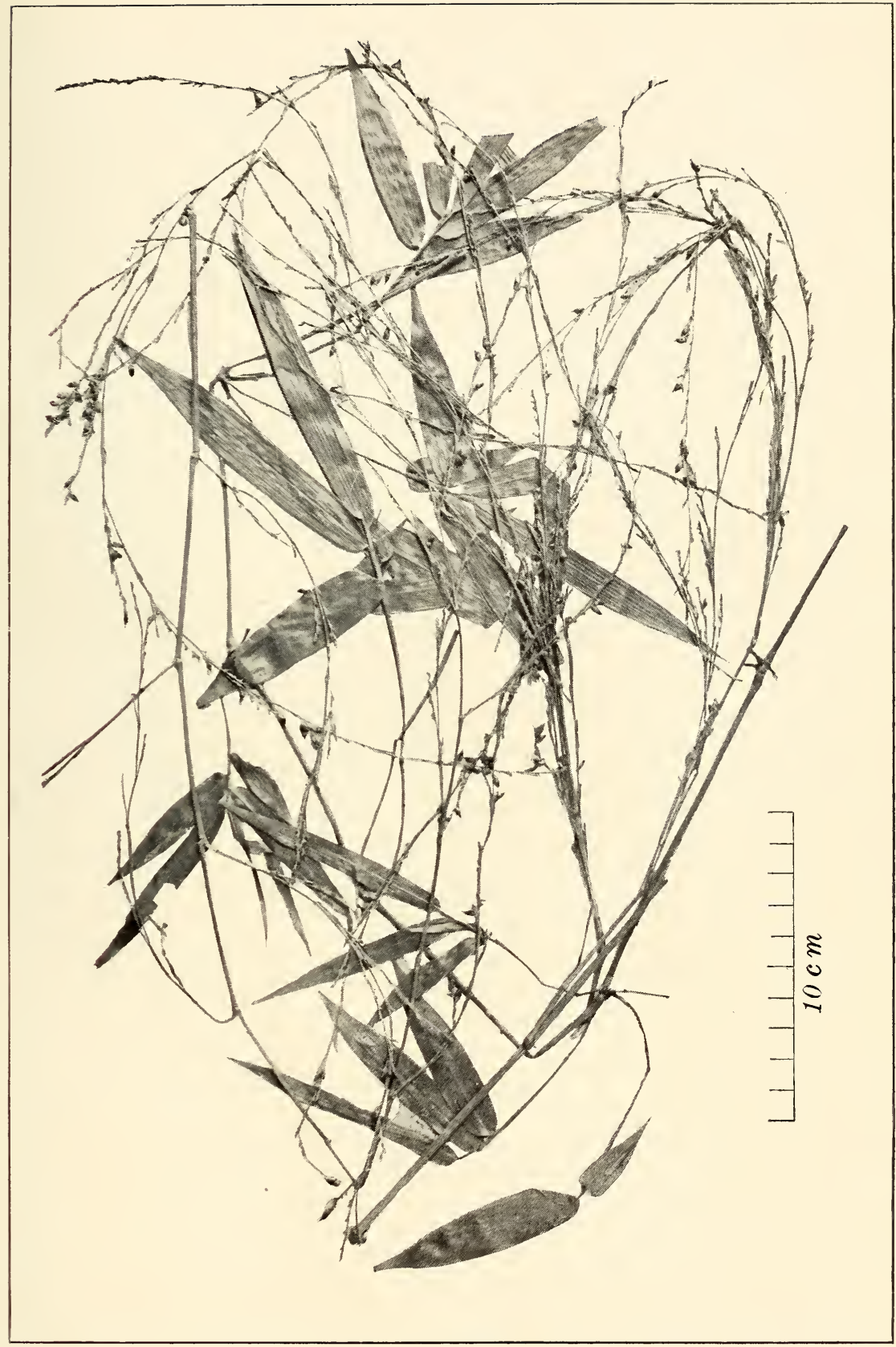

PLATE XVI. DINOCHLOA LUÇONIAE (MUNRO) MERR. 


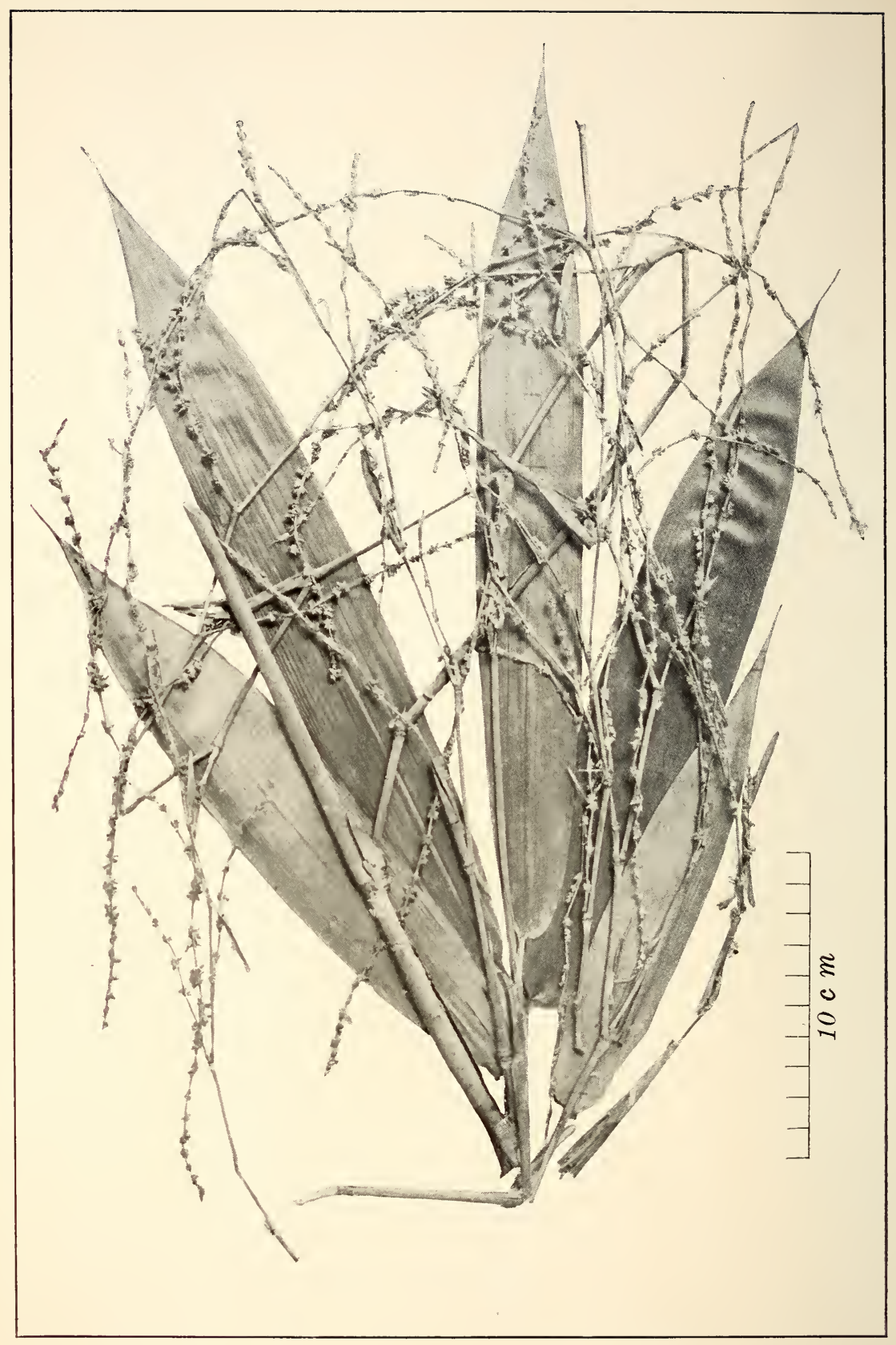

PLATE XVII. DINOCHLOA PUBIRAMEA GAMBLE. TYPE SPECIMEN. 


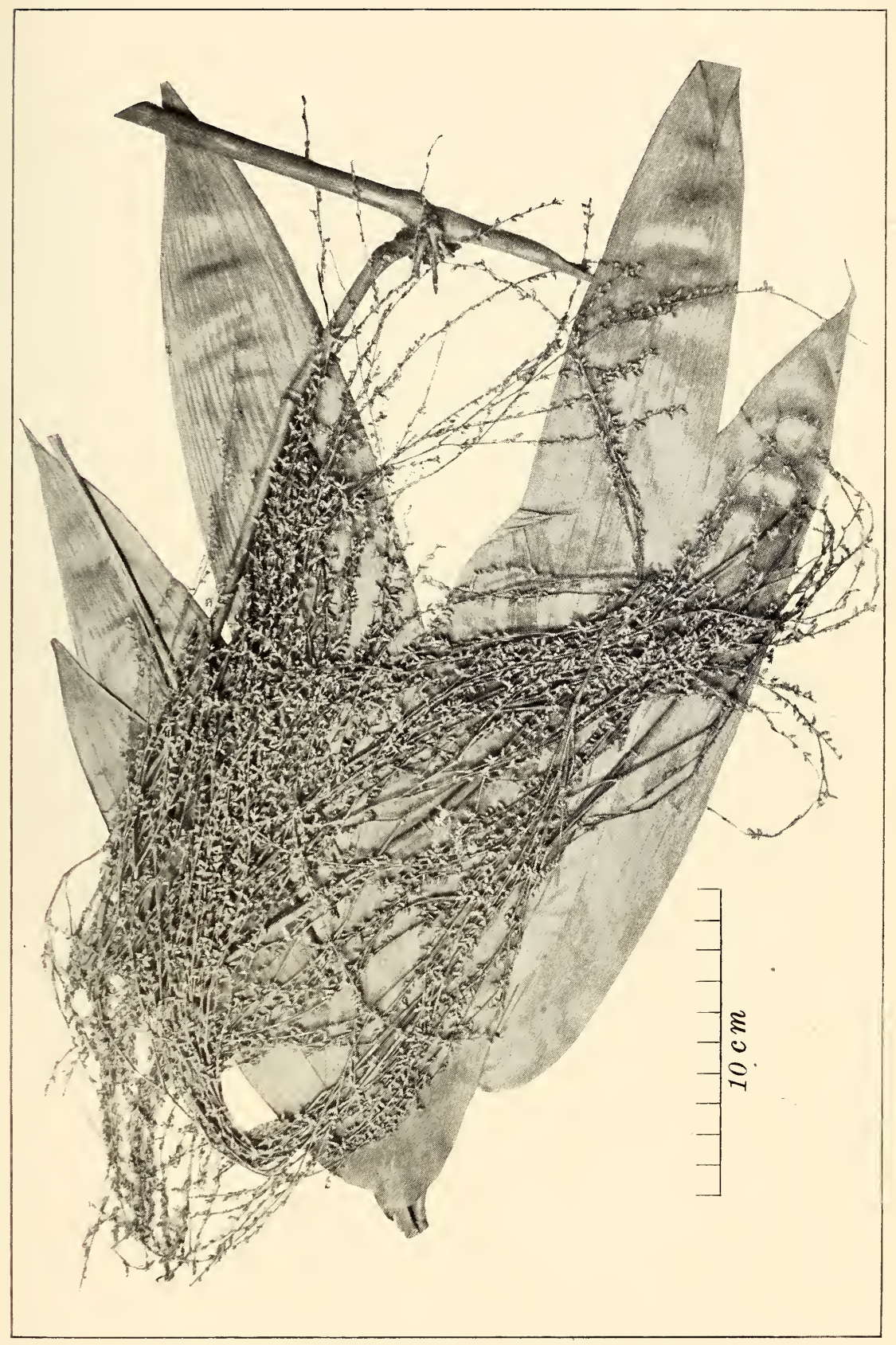

PLATE XVIII. DINOCHLOA SCANDENS O. KUNTZE. 


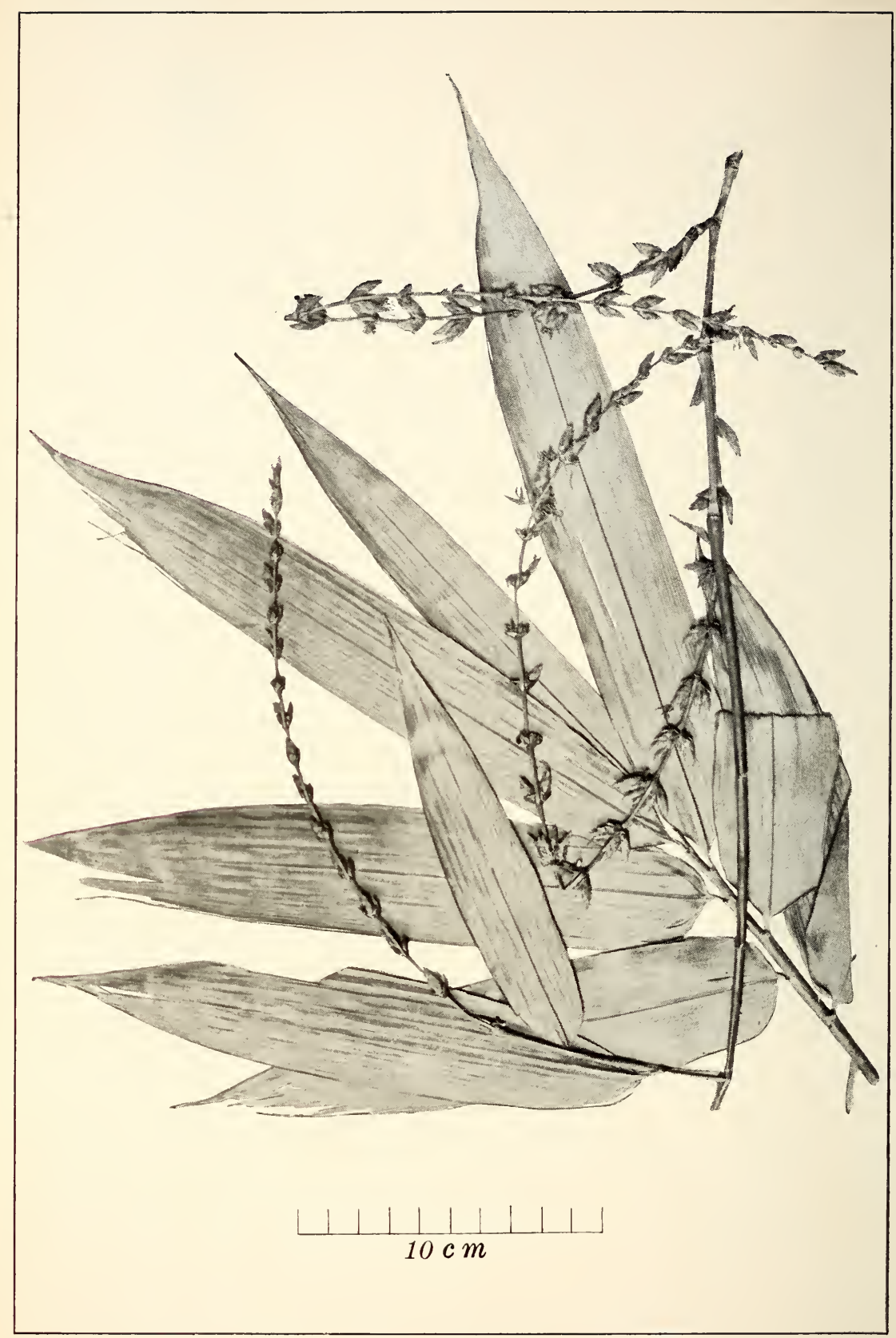

PLATE XIX. GIGANTOCHLOA LEVIS (BLANCO) MERR. 


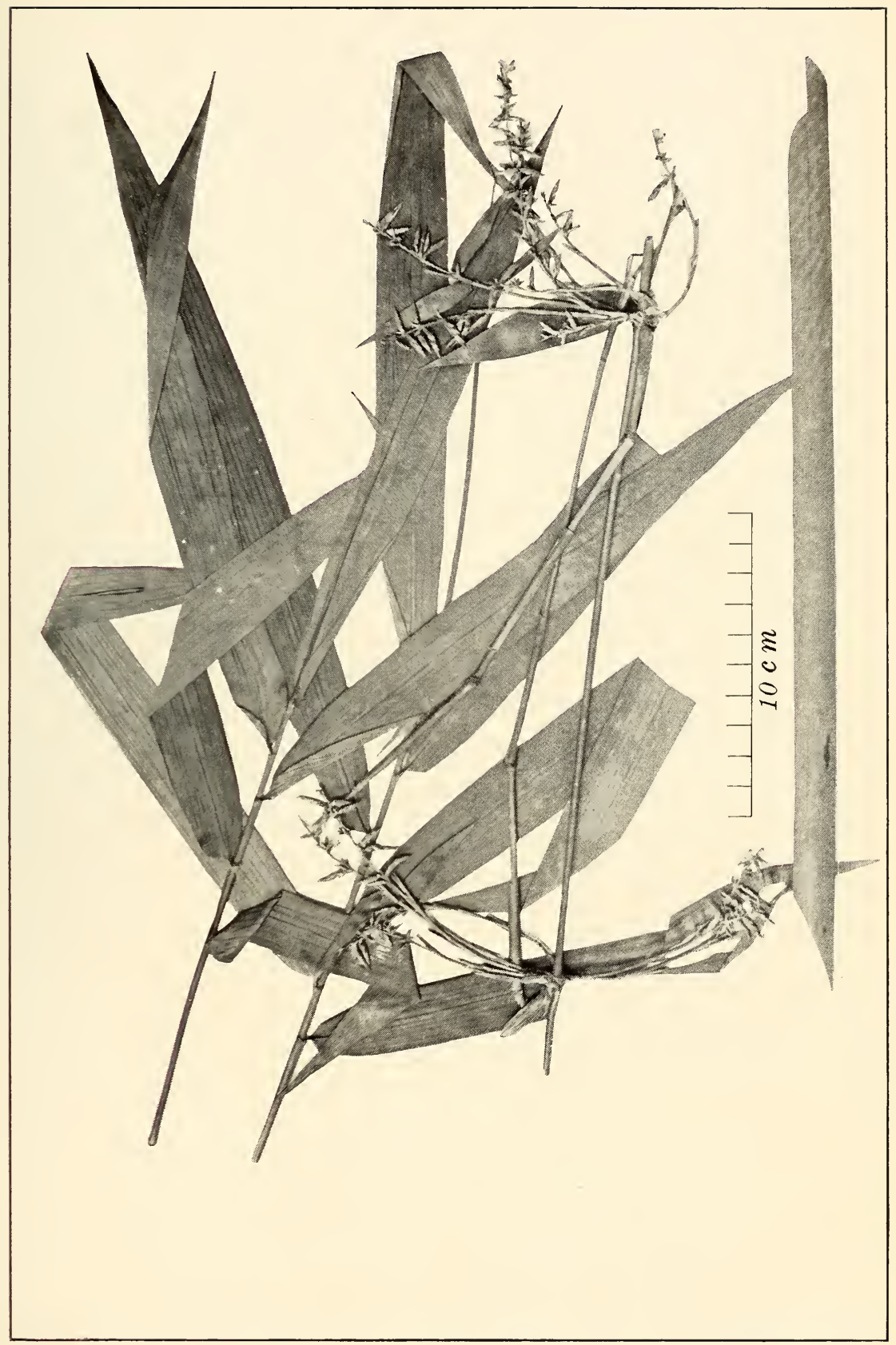

PLATE XX. GUADUA PHILIPPINENSIS GAMBLE. COTYPE SPECIMEN. 


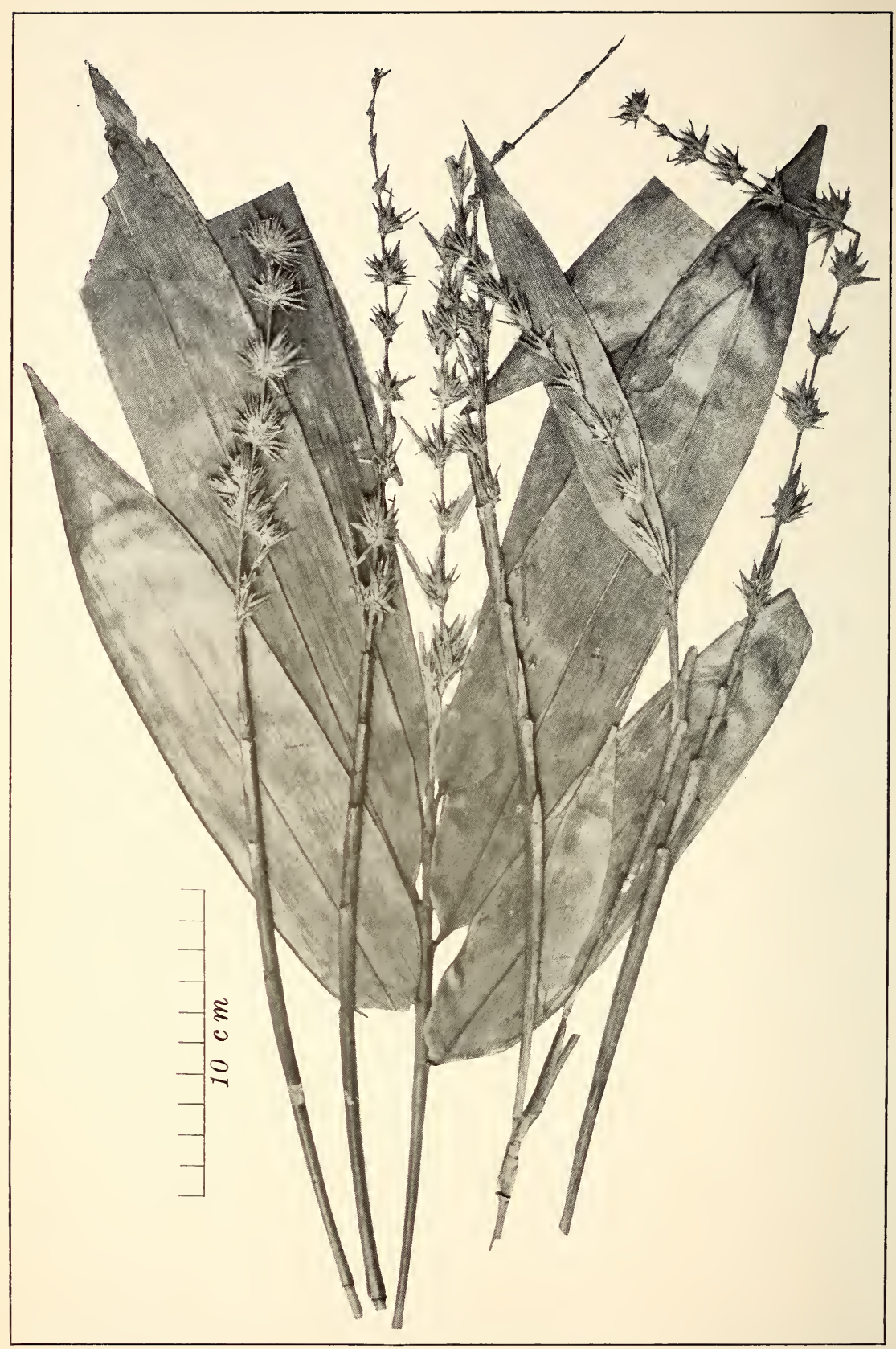

PLATE XXI. SCHIZOSTACHYUM BRACHYCLADUM KURZ. 


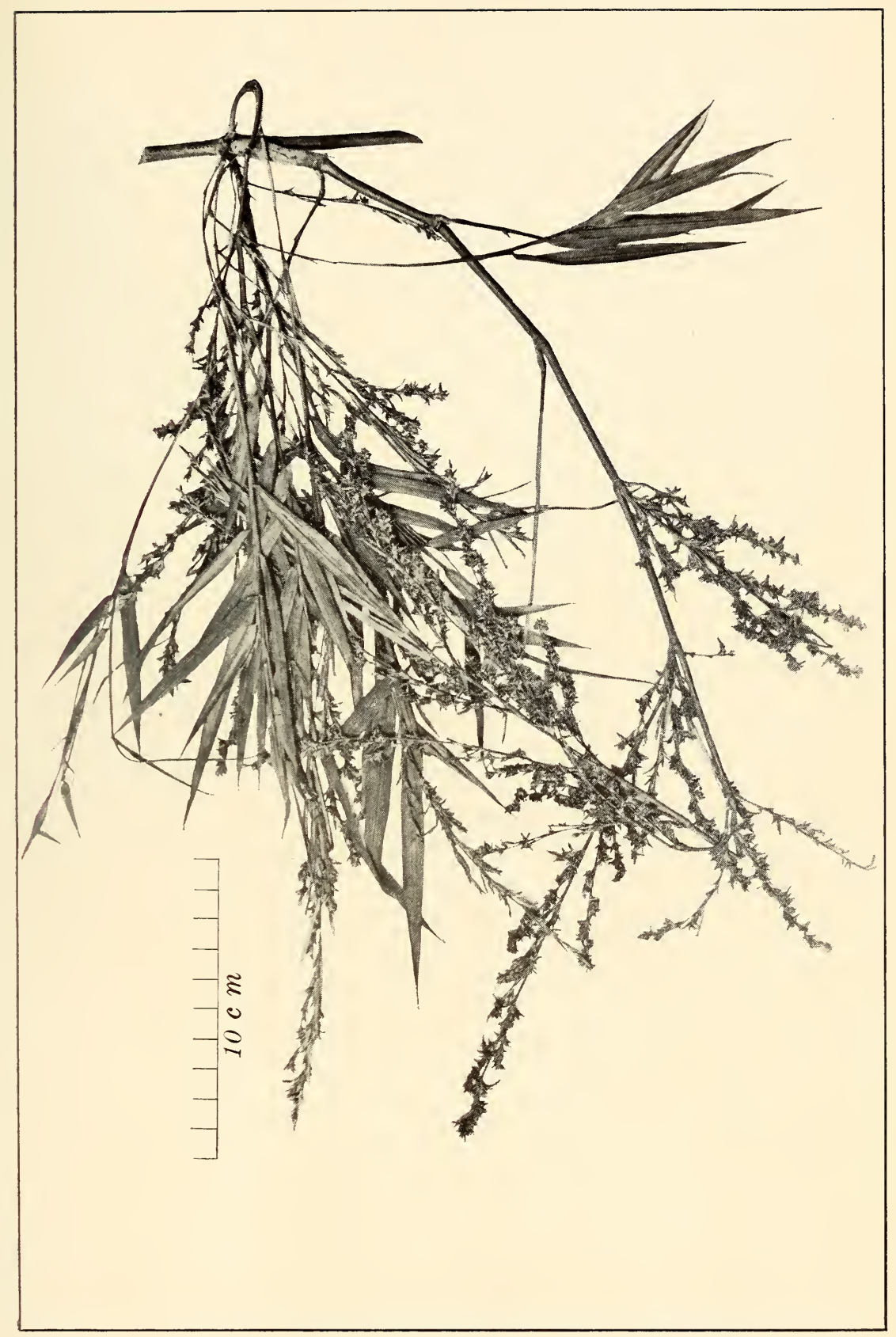

PLATE XXII. SCHIZOSTACHYUM DIELSIANUM (PILGER) MERR. 


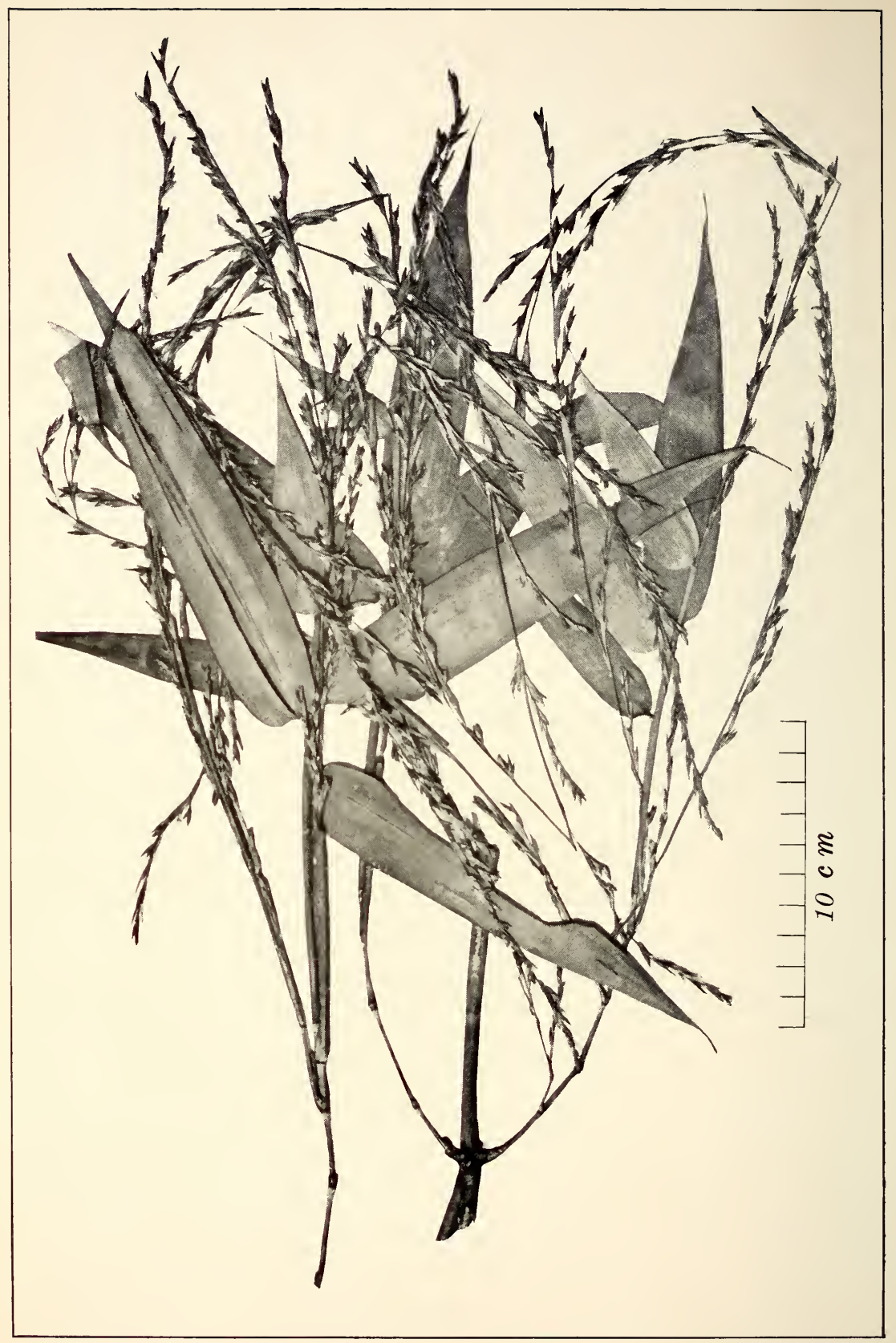

PLATE XXIII. SCHIZOSTACHYUM CURRANII GAMBLE. 


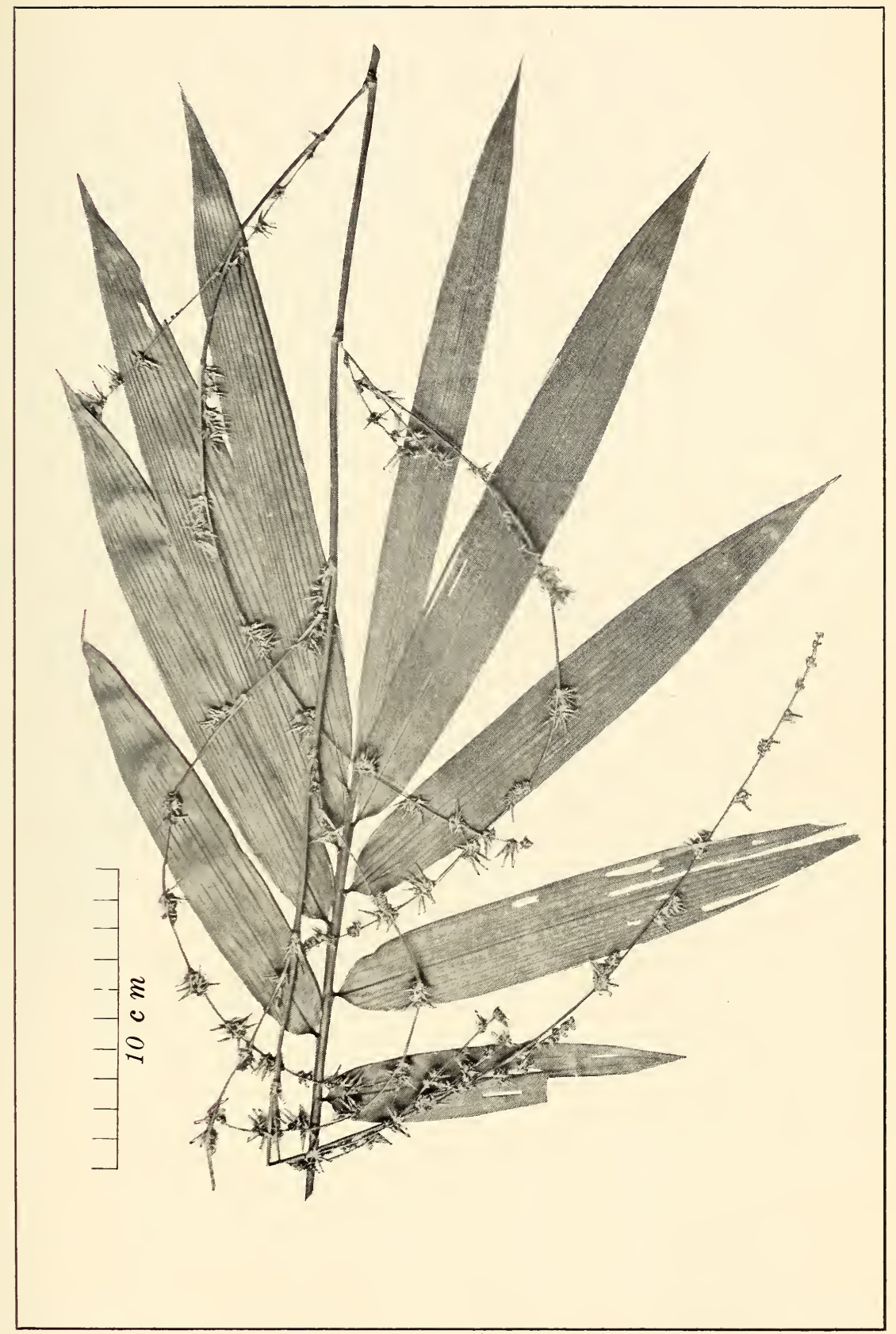

PLATE XXIV. SCHIZOSTACHYUM DIFFUSUM (BLANCO) MERR. 


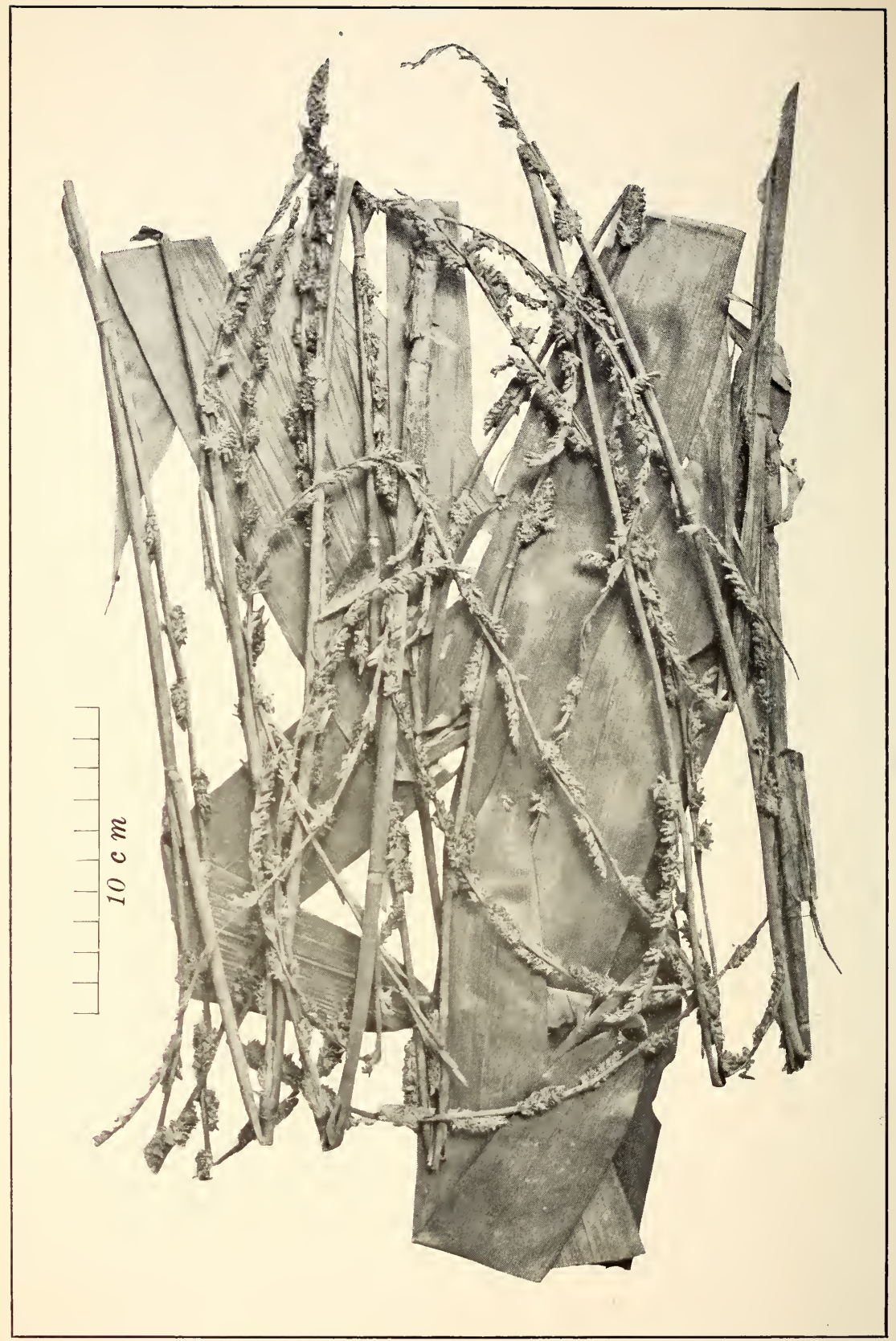

PLATE XXV. SCHIZOSTACHYUM FENIXII GAMBLE. COTYPE SPECIMEN. 



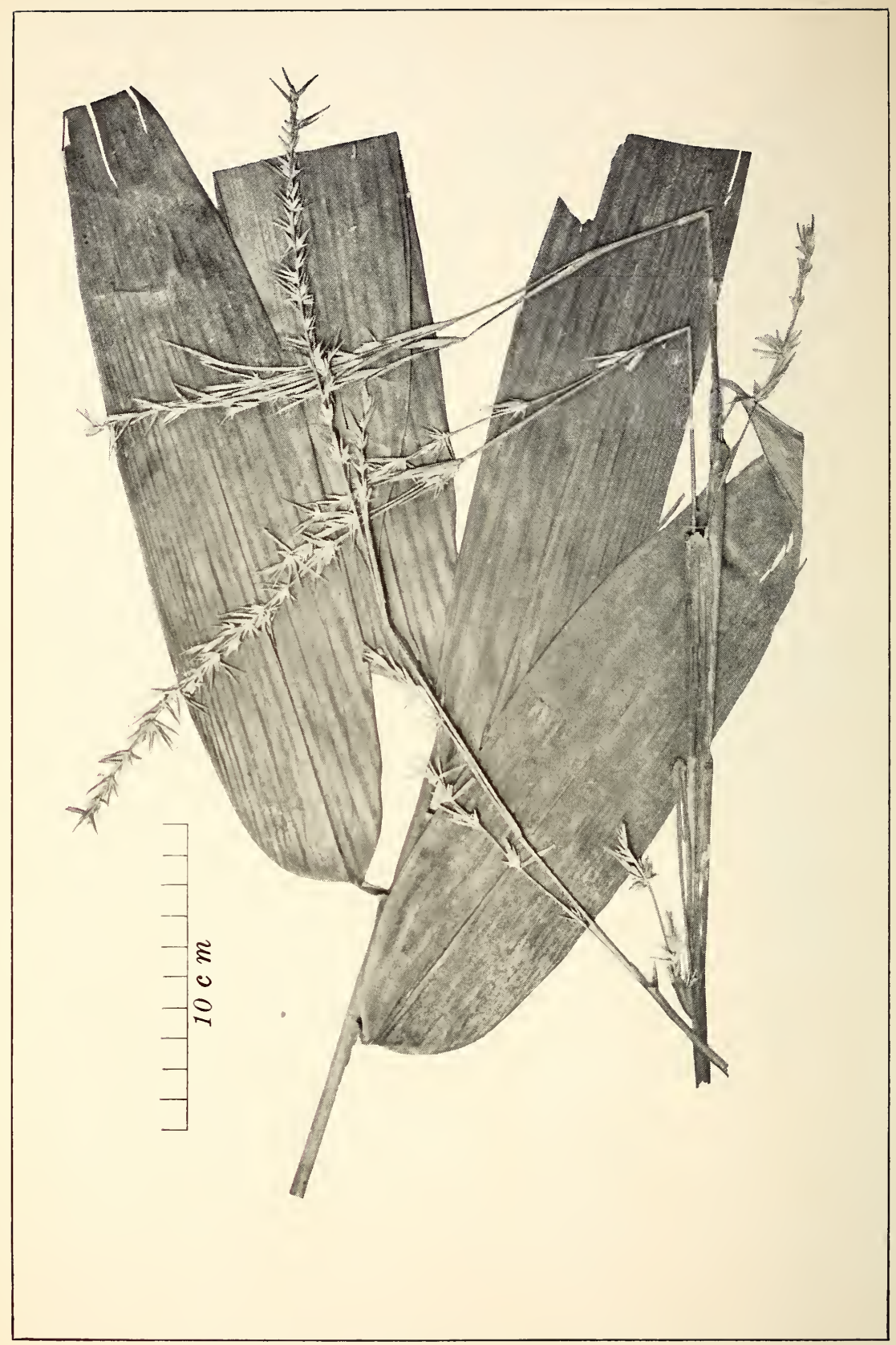

PLATE XXVII. SCHIZOSTACHYUM LIMA (BLANCO) MERR. 


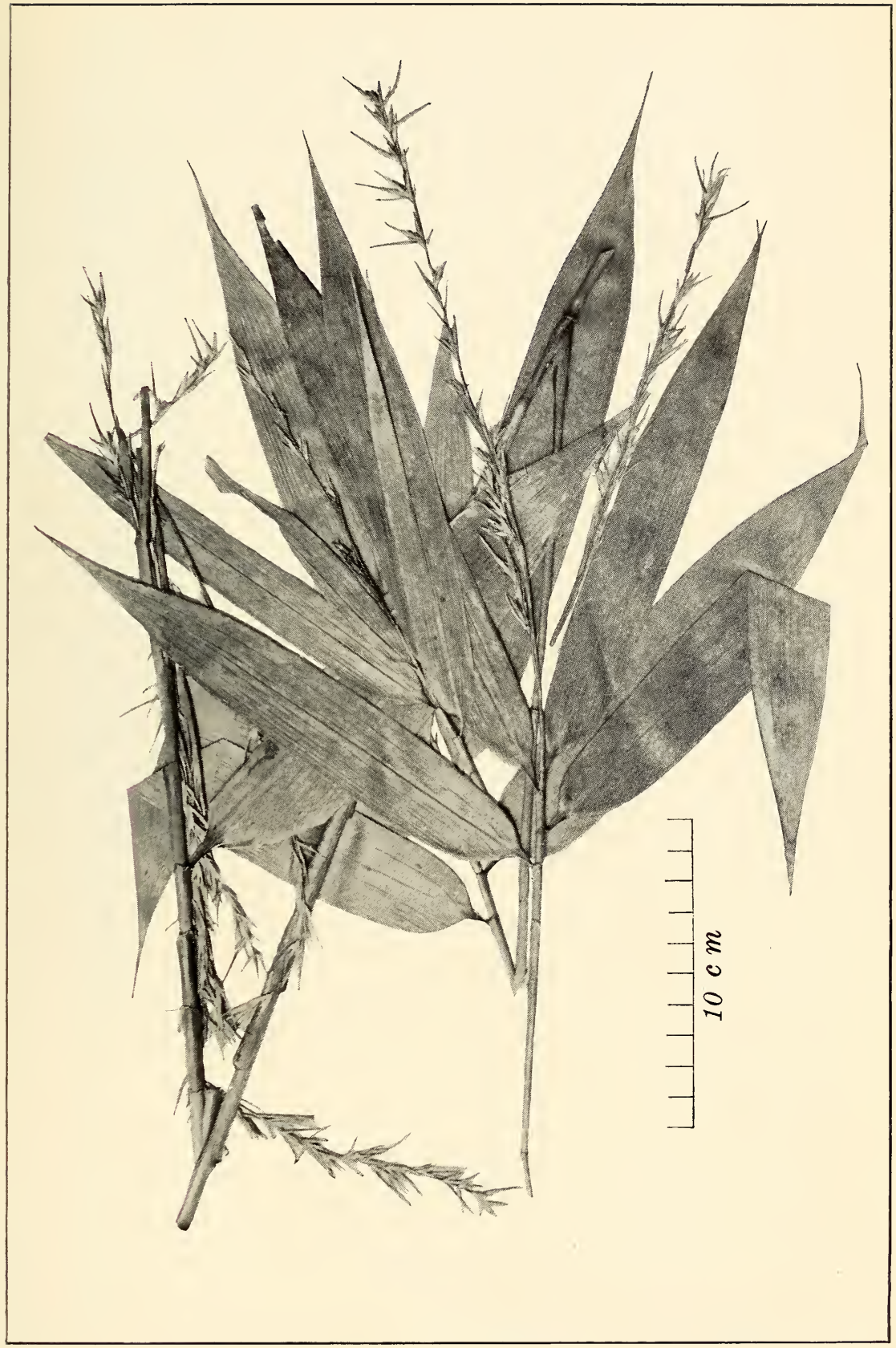

PLATE XXVIII. SCHIZOSTACHYUM LUMAMPAO (BLANCO) MERR. 


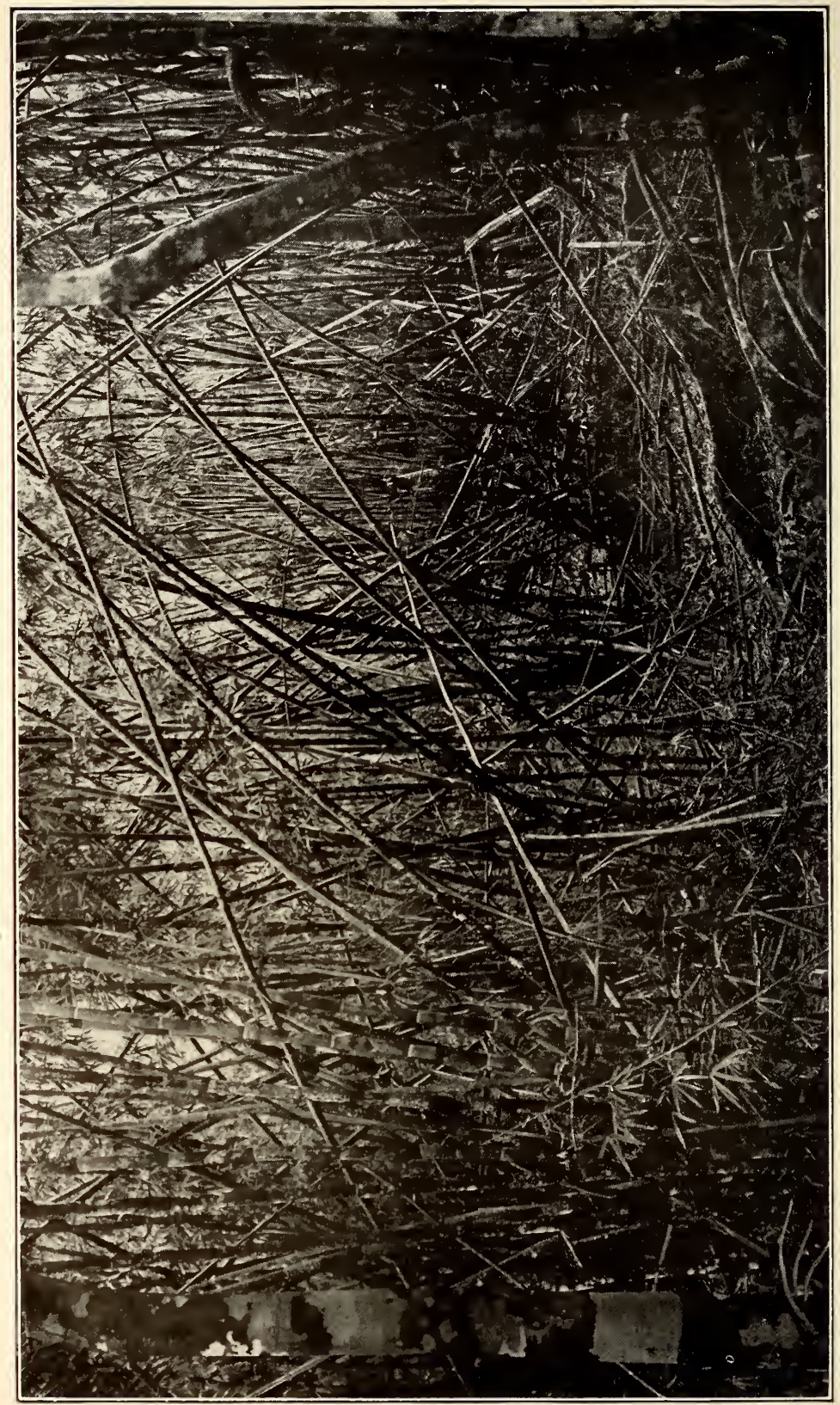

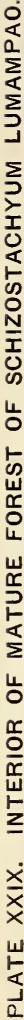




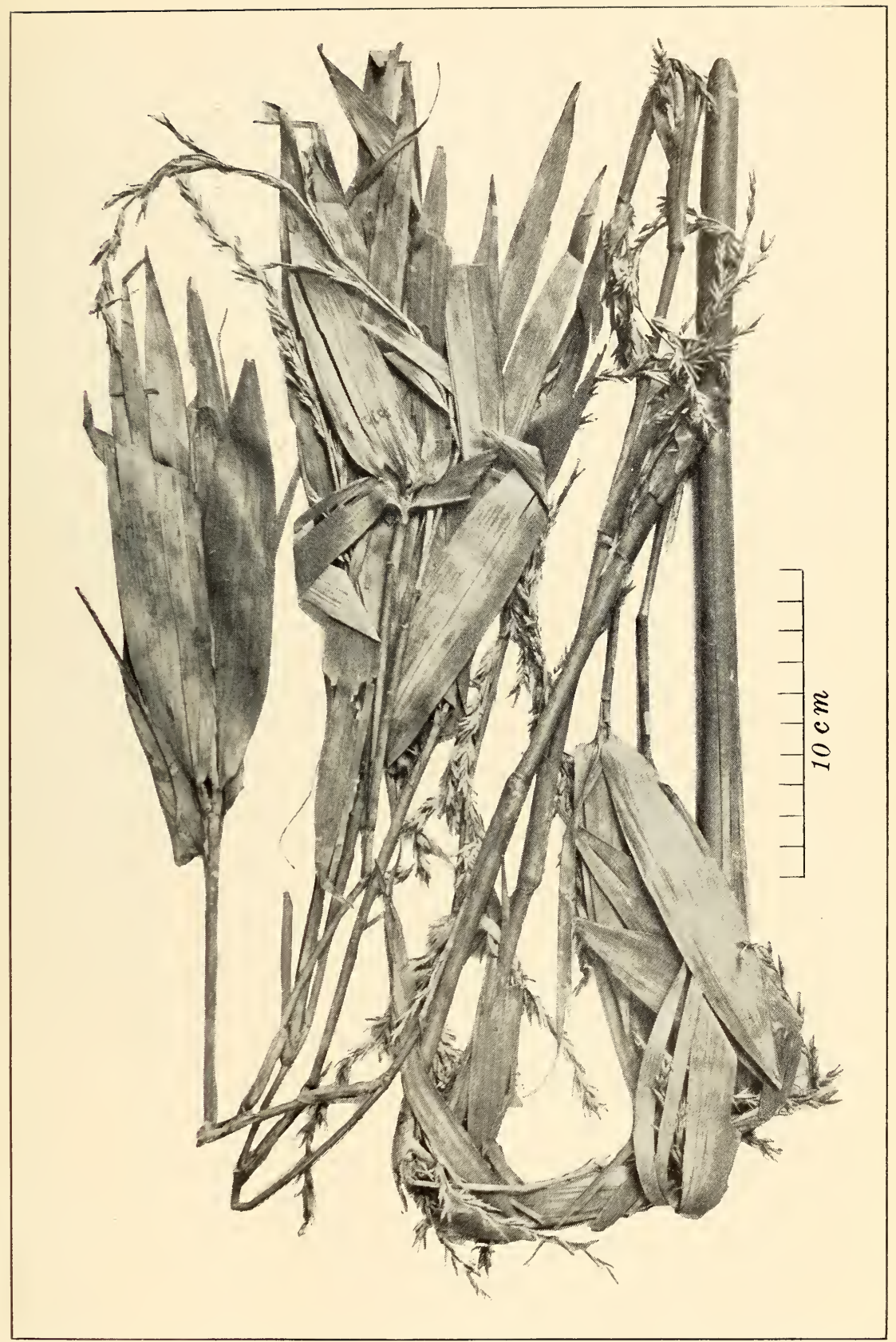

PLATE XXX. SCHIZOSTACHYUM LUZONICUM GAMBLE. COTYPE SPECIMEN. 


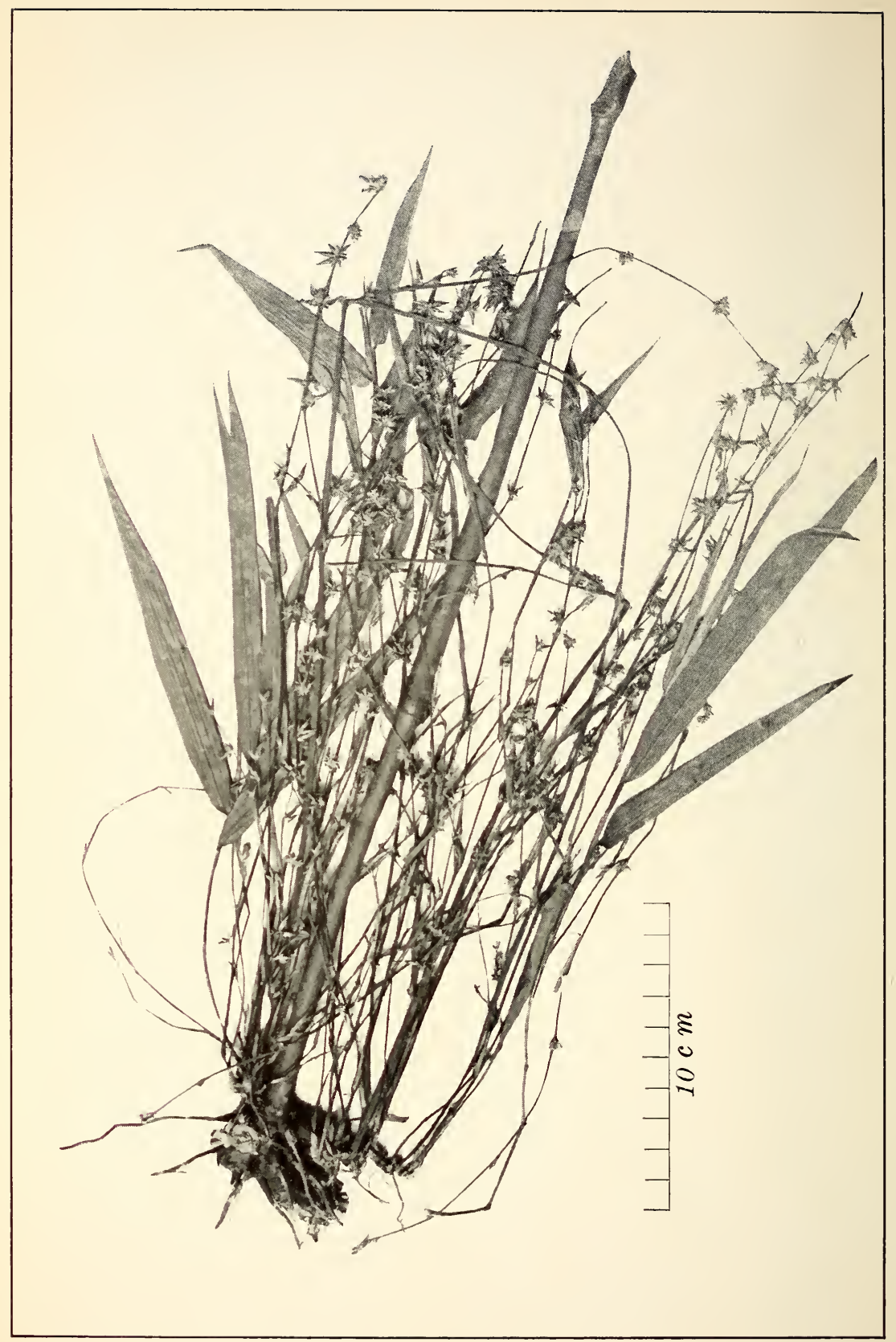

PLATE XXXI. SCHIZOSTACHYUM PALAWANENSE GAMBLE. TYPE SPECIMEN. 


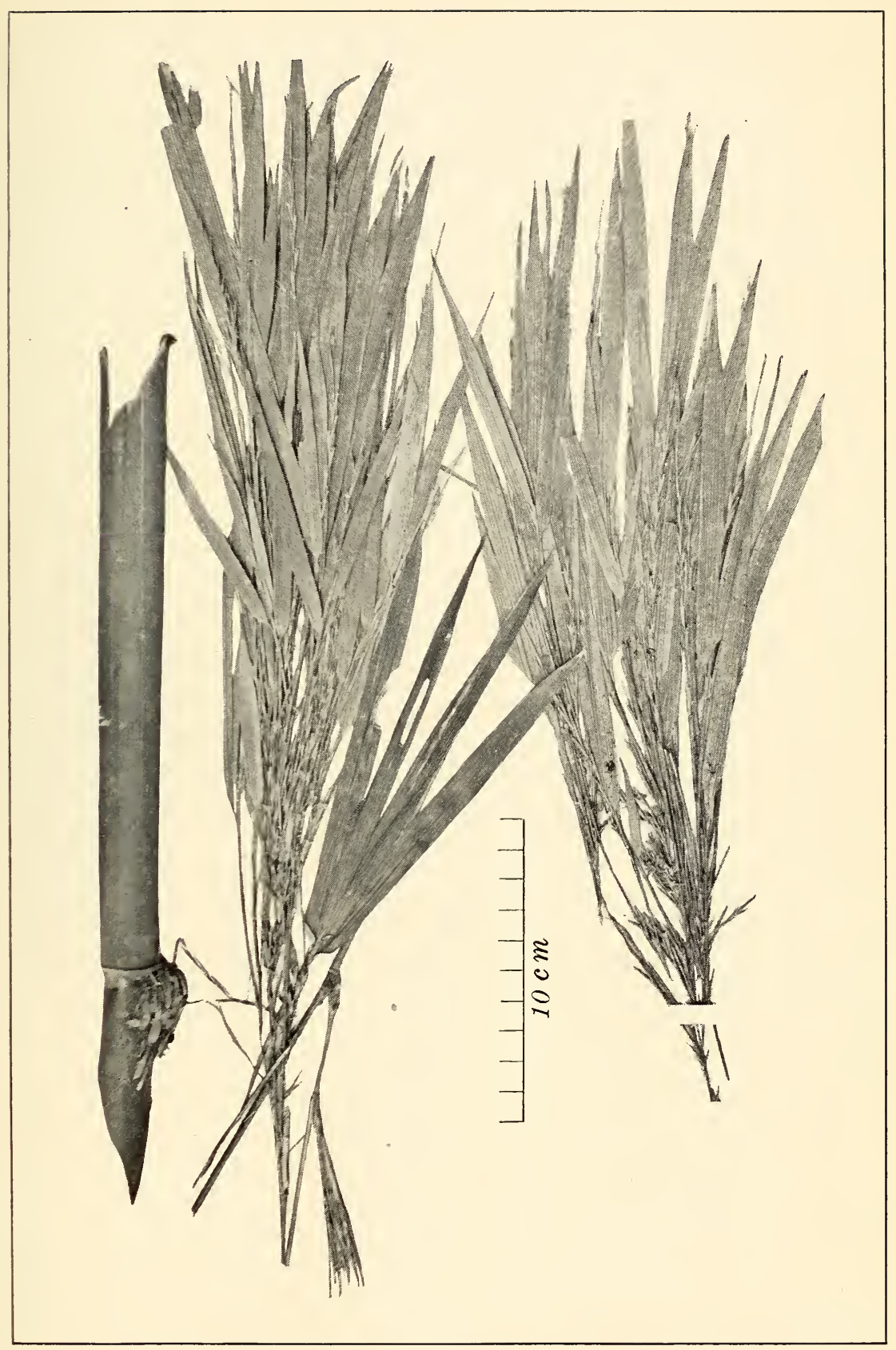

PLATE XXXII. SCHIZOSTACHYUM TEXTORIUM (BLANCO) MERR. $160091-5$ 


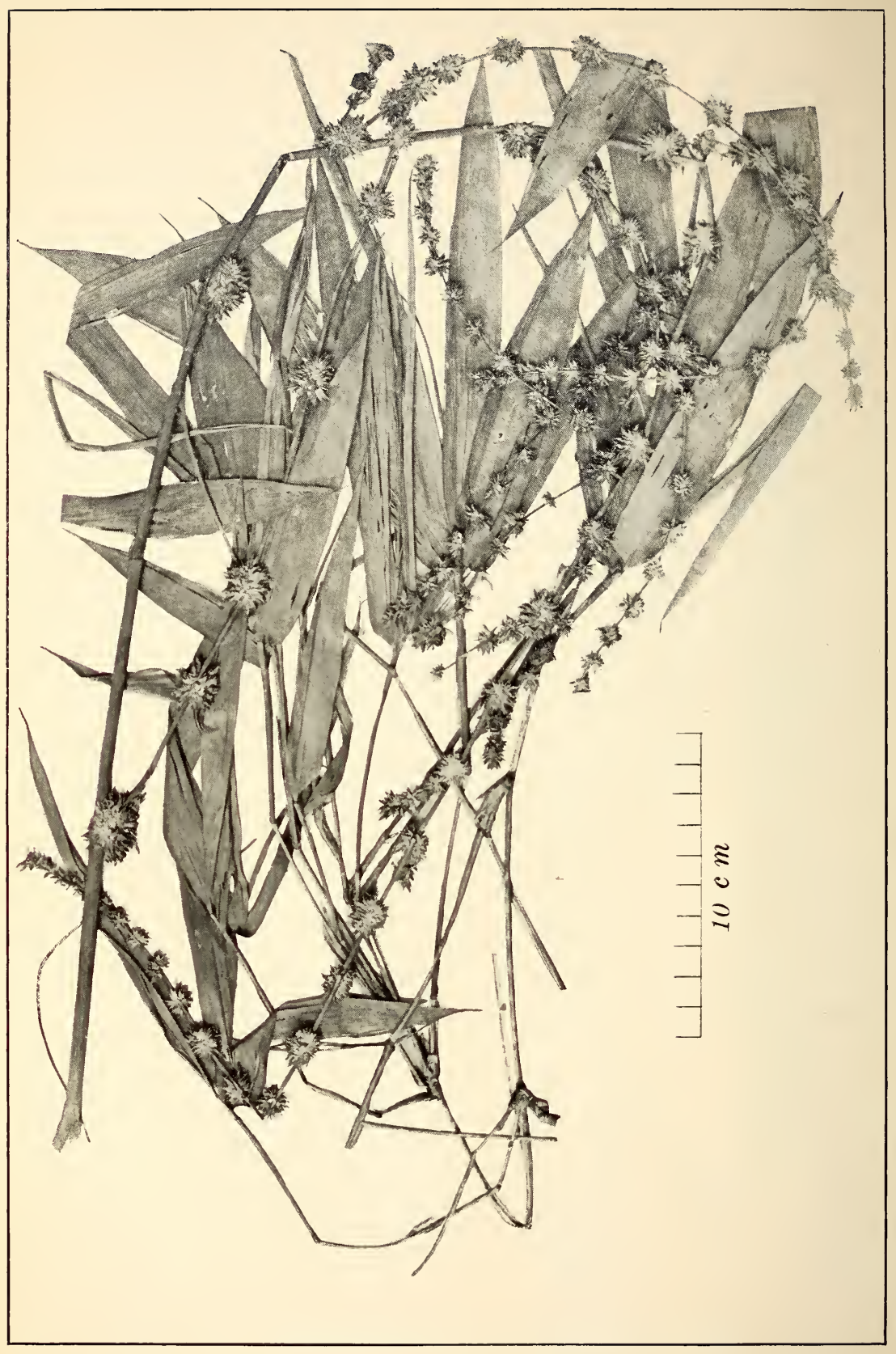

PLATE XXXIII. SCHIZOSTACHYUM TOPP!NGII GAMBLE. COTYPE SPECIMEN. 


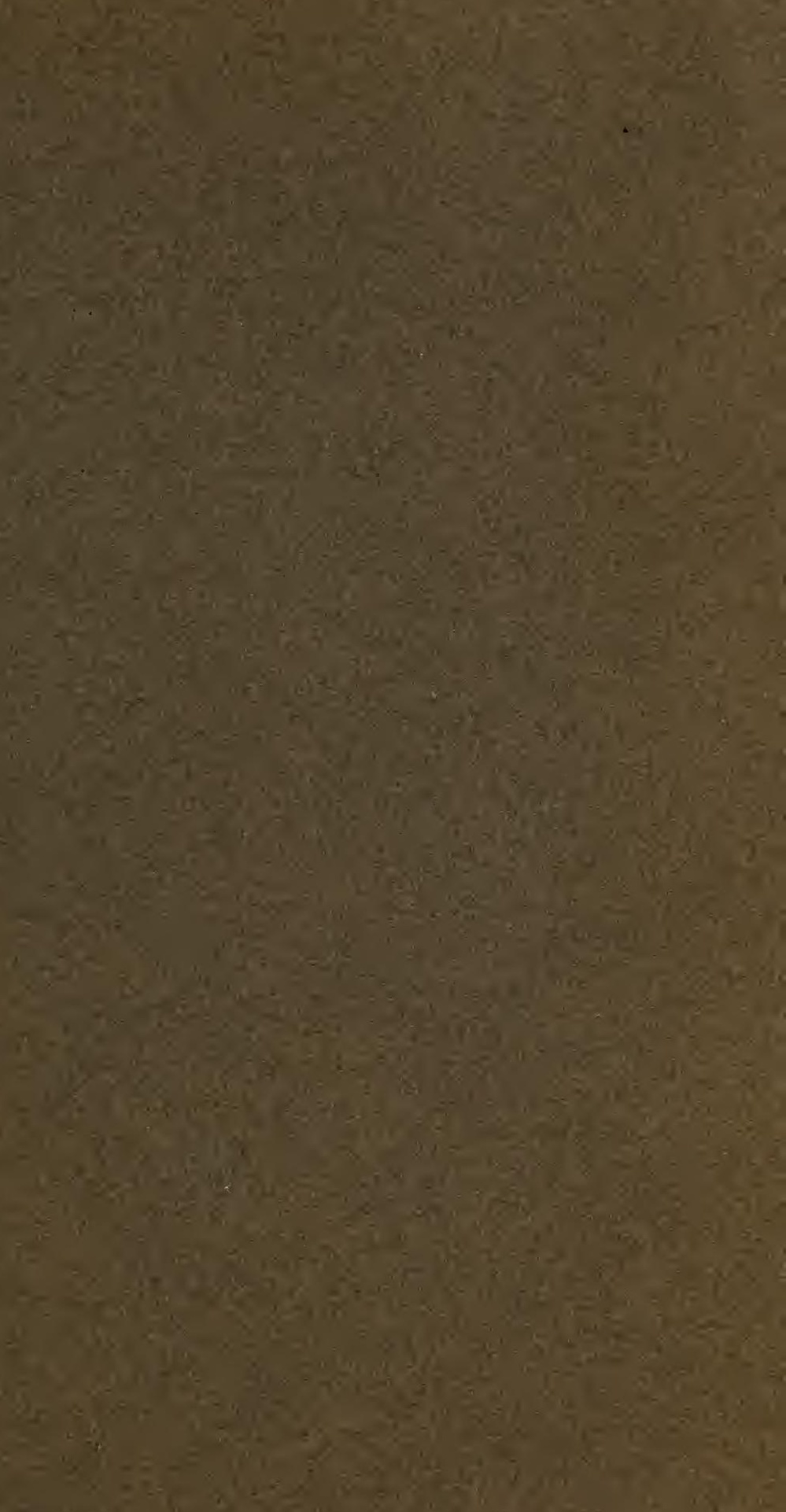

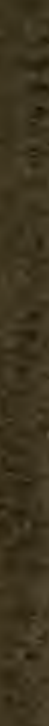

184

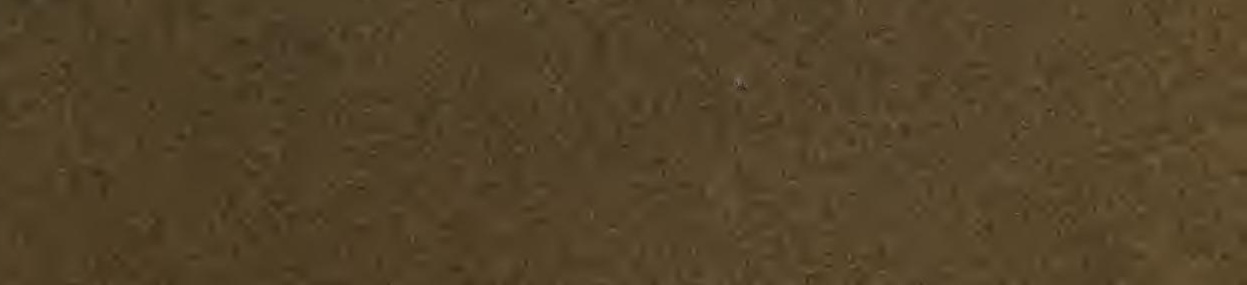




\section{BUREAU OF FORESTRY \\ MANILA, PHILIPPINE ISLANDS}

Bulletin No. 1 (1903). - Report on investigations made in Java in the year 1902. By Elmer D. Merrill. Out of print.

Bulletin No. 2 (1906). - The charcoal industry of the Philippine Islands. By Wm. M. Maule. Out of print:

Bulletin No. 3 (1906). - A compilation of notes on india rubber and guttapercha. Out of print.

Bulletin No. 4 (1906).-I. Mechanical tests, properties, and uses of thirty Philippine woods. II. Philippine sawmills, lumber market, and prices. By Rolland Gardner. Out of print.

Bulletin No. 5 (1906). - A preliminary working plan for the public forest tract of the Insular Lumber Company, Negros Occidental, P. I. By H. D. Everett and H. N. Whitford. Out of print.

Bulletin No. 6 (1906). A preliminary working plan for the public forest tract of the Mindoro Lumber and Logging Company, Bongabon, Mindoro, P. I. By M. L. Merritt, and H. N. Whitford. Out of print.

Bulletin No. 7 (1907).-A preliminary check list of the principal commercial timbers of the Philippine Islands. By H. N. Whitford. Out of print.

Bulletin No. 8 (1908).-The forests of Mindoro. By Melvin L. Merritt. Out of print.

Bulletin No. 9 (1909).-A Philippine substitute for lignum-vitae. By W. I. Hutchinson. 60 centavos.*

Bulletin No. 10 (1911).-The forests of the Philippines. I. Forest types and products. II. The principal forest trees. By H. N. Whitford. 2.50 pesos.

Bulletin No. 11 (1912).-The uses of Philippine woods. Out of print.

Bulletin No. 12 (1912).-Volume tables for round timber. Compiled by William Klemme. Out of print.

Bulletin No. 13 (1915), - Ipil-ipil. A frewood and reforestation crop. By D. M. Mathews. 50 centavos.

Bulletin No. 14 (1916).-Commercial woods of the Philippines; their preparation and uses. By E. E. Schneider. 2 pesos.

Bulletin No. 15 (1918).-Philippine bamboos. By William H. Brown and Arthur F. Fischer. 1.50 pesos.

Bulletin No, 16 (1918):--Paper materials from Philippine forest areas. By

William H. Brown and Arthur F. Fischer. 50 centavos.

Bulletin No. 17 (1918)--Philippine mangrove swamps. By William $H$. Brown and Arthur F. Fischer. 2 pesos.

- Fifty cents U. S. currency equals 1 peso or 100 centavos 





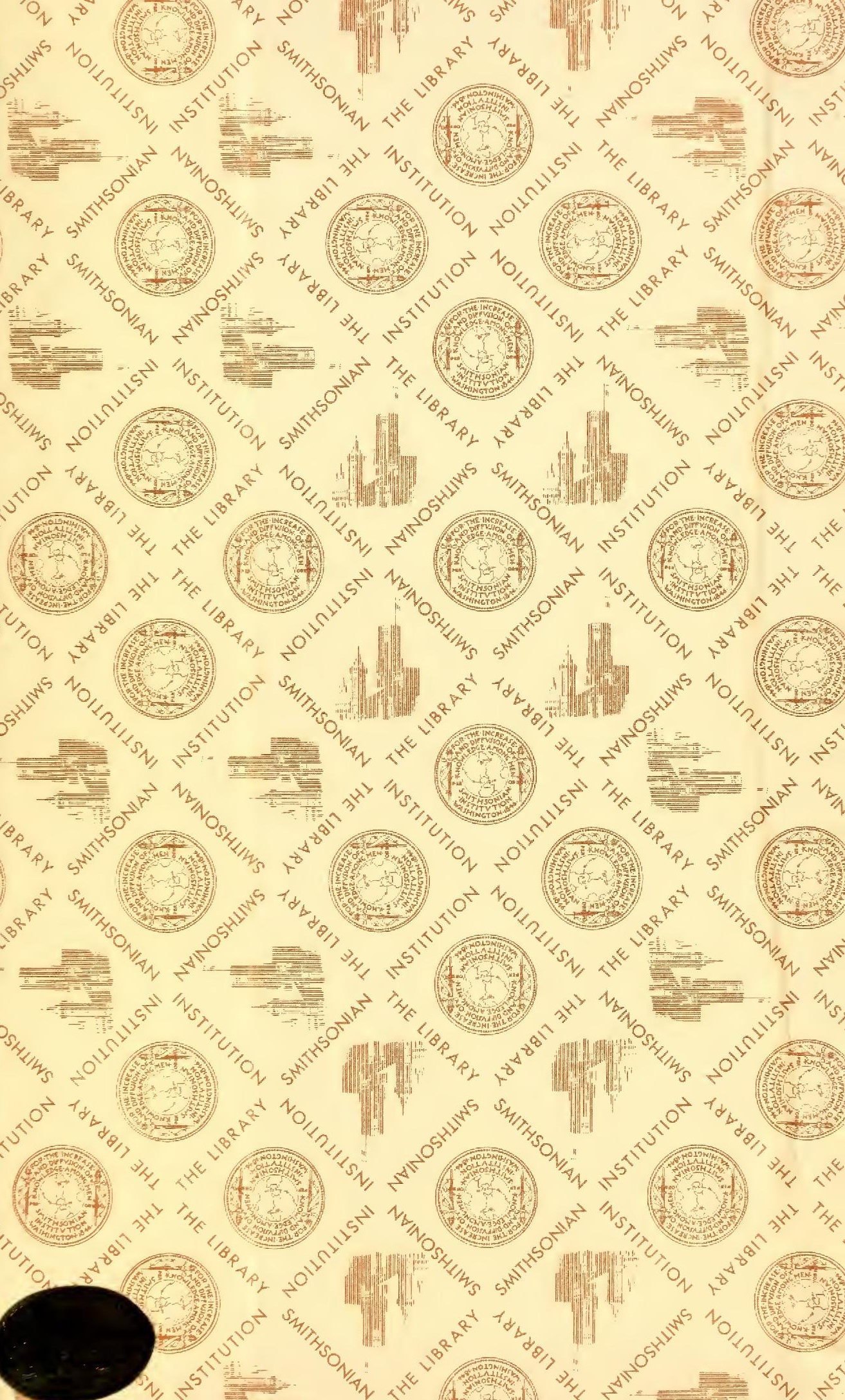


SMITHSONIAN INSTITUTION LIBRARIES 